
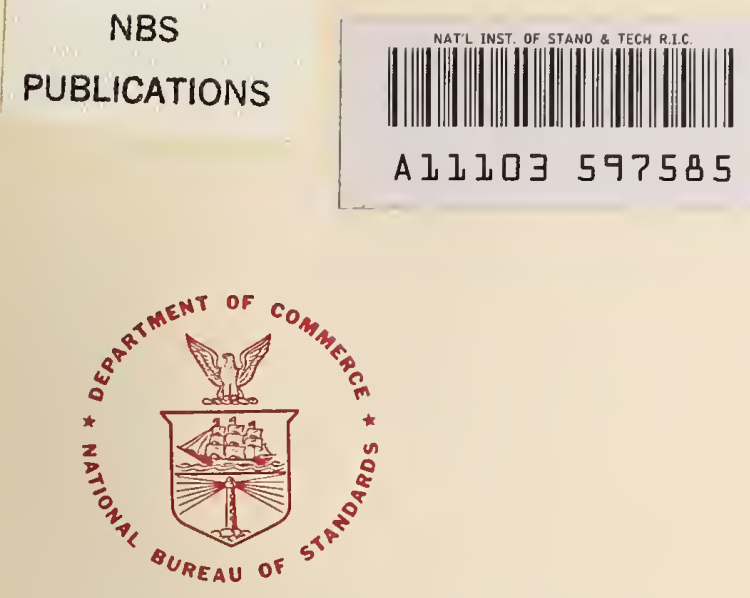

NBS TECHNICAL NOTE 1203

U.S. DEPARTMENT OF COMMERCE/National Bureau of Standards

\title{
A Benefit-Cost Model of Residential Fire Sprinkler Systems
}


he National Bureau of Standards ${ }^{1}$ was established by an act of Congress on March 3, 1901. The Bureau's overall goal is to strengthen and advance the nation's science and technology and facilitate their effective application for public benefit. To this end, the Bureau conducts research and provides: (1) a basis for the nation's physical measurement system, (2) scientific and technological services for industry and government, (3) a technical basis for equity in trade, and (4) technical services to promote public safety. The Bureau's technical work is performed by the National Measurement Laboratory, the National Engineering Laboratory, the Institute for Computer Sciences and Technology, and the Center for Materials Science.

\section{The National Measurement Laboratory}

Provides the national system of physical and chemical measurement; coordinates the system with measurement systems of other nations and furnishes essential services leading to accurate and uniform physical and chemical measurement throughout the Nation's scientific community, industry, and commerce; provides advisory and research services to other Government agencies; conducts physical and chemical research; develops, produces, and distributes Standard Reference Materials; and provides calibration services. The Laboratory consists of the following centers:
- Basic Standards ${ }^{2}$

- Radiation Research

- Chemical Physics

- Analytical Chemistry

\section{The National Engineering Laboratory}

Provides technology and technical services to the public and private sectors to address national needs and to solve national problems; conducts research in engineering and applied science in support of these efforts; builds and maintains competence in the necessary disciplines required to carry out this research and technical service; develops engineering data and measurement capabilities; provides engineering measurement traceability services; develops test methods and proposes engineering standards and code changes; develops and proposes new engineering practices; and develops and improves mechanisms to transfer results of its research to the ultimate user. The Laboratory consists of the following centers:
- Applied Mathematics

- Electronics and Electrical Engineering $^{2}$

- Manufacturing Engineering

- Building Technology

- Fire Research

- Chemical Engineering ${ }^{2}$

\section{The Institute for Computer Sciences and Technology}

Conducts research and provides scientific and technical services to aid Federal agencies in the selection, acquisition, application, and use of computer technology to improve effectiveness and economy in Government operations in accordance with Public Law 89-306 (40 U.S.C. 759), relevant Executive Orders, and other directives; carries out this mission by managing the Federal Information Processing Standards Program, developing Federal ADP standards guidelines, and managing Federal participation in ADP voluntary standardization activities; provides scientific and technological advisory services and assistance to Federal agencies; and provides the technical foundation for computer-related policies of the Federal Government. The Institute consists of the following centers:
- Programming Science and Technology

- Computer Systems Engineering

\section{The Center for Materials Science}

Conducts research and provides measurements, data, standards, reference materials, quantitative understanding and other technical information fundamental to the processing, structure, properties and performance of materials; addresses the scientific basis for new advanced materials technologies; plans research around cross-country scientific themes such as nondestructive evaluation and phase diagram development; oversees Bureau-wide technical programs in nuclcar reactor radiation research and nondestructive evalualion; and broadly disseminates generic technical information resulting from its programs. The Center consists of the following Divisions:
- Inorganic Materials

- Fracture and Deformation ${ }^{3}$

- Polymers

- Metallurgy

- Reactor Radiation 


\section{A Benefit-Cost Model of Residential Fire Sprinkler Systems}

Rosalie T. Ruegg

Sieglinde K. Fuller

Operations Research Division

Center for Applied Mathematics

National Engineering Laboratory

National Bureau of Standards

Gaithersburg, MD 20899

Prepared for:

Fire Safety Technology Division

Center for Fire Research

National Engineering Laboratory

National Bureau of Standards

Gaithersburg, MD 20899

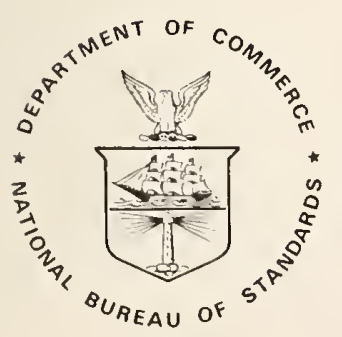

U.S. DEPARTMENT OF COMMERCE, Malcolm Baldrige, Secretary NATIONAL BUREAU OF STANDARDS, Ernest Ambler, Director 
National Bureau of Standards Technical Note 1203

Natl. Bur. Stand. (U.S.), Tech. Note 1203, 149 pages (Nov. 1984)

CODEN: NBTNAE 


\section{PREFACE}

This study was conducted at the National Bureau of Standards (NBS), by the Operations Research Division of the Center for Applied Mathematics for the Fire Safety Technology Division of the Center for Fire Research.

The purpose of the study is to develop decision models for evaluating the cost effectiveness of providing fire loss protection in houses through the use of automatic sprinkler systems. The focus is on modeling the investment decision as it affects the individual homeowner. The model of the homeowner's investment decision is illustrated in selected hypothetical cases, an appendix to the report develops parallel decision models from the standpoint of developers and local governments. The intended audiences of the report are principally managers of government agencies and private organizations concerned with the research, development, and commercialization of residential sprinkler technology. It may also be of interest to developers, city planners and managers, building owners and users, and other members of the building community who are interested in the economics of sprinklers in home fire protection. 


\section{ACKNOWLEDGMENTS}

Special appreciation is extended to members of the Center for Fire Research who provided advice on technical aspects of sprinkler systems: Jack Snell, Center Director; Andrew Fowe11, Chief of the Fire Safety Technology Division; Alan Gomberg, former Acting Leader of the Fire Hazard Analysis Group; and John Ha11 and Wayne Stiefe1, members of that group.

The authors also wish to thank Harold Marshall and Robert Chapman, both of the NBS Center for Applied Mathematics, and Joseph Greenberg of the Center for Building Technology, for their helpful reviews of the report. Special credit is due Barbara Lippiatt, of the Center for Applied Mathematics, for her excellent assistance in compiling cost data.

Finally, the authors wish to acknowledge the invaluable assistance and cooperation they received from people in private industry, nonprofit organizations, and local government in estimating the costs and benefits of sprinkler systems. 


\section{ABSTRACT}

This paper develops and applies decision models for evaluating the economic efficiency of providing fire loss mitigation in houses through the use of a new technology: fast-response sprinkler systems. A model is developed for calculating present value net benefits as they would accrue to an owneroccupant or an owner of a rental house who installs a sprinkler system. Costs and benefits of owning a system are estimated for selected hypothetical cases pertaining to a new, single-family dwelling in the United States. The estimates are then used to illustrate the model. Minimum or maximum values that key decision variables must take in order for sprinkler systems to be cost effective in the selected applications are calculated through break-even analysis. Related models are developed for evaluating the economic merits of sprinkler systems from the standpoint of developers and local governments. Implications for the research and building communities are discussed.

Keywords: Building economics; economic analysis; fire protection; life-cycle costing; net benefit analysis; residential fire safety; riskbenefit analysis; sprinkler systems. 
PREFACE.......................................

ACKNOWLEDGMENTS ................................ iv

ABSTRACT. ....................................... v

LIST OF FIGURES................................. viii

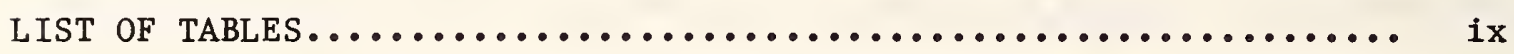

EXECUTIVE SUMMARY $\ldots \ldots \ldots \ldots \ldots \ldots \ldots \ldots \ldots \ldots \ldots \ldots \ldots \ldots \ldots \ldots \ldots \ldots \ldots$

1. INTRODUCTION.................................. 1

1.1 Background.................................. 1

1.2 Purpose, Approach, Scope and Organization............. 7

2. METHODOLOGY.................................... 10

2.1 The Decision Process........................... 10

2.2 Model of the Homeowner's Investment Decision........... 11

2.3 Evaluation Techniques Used in the Mode1.............. 24

2.4 Economic Parameters and Assumptions................. 29

3. SELECTED APPLications............................. 33

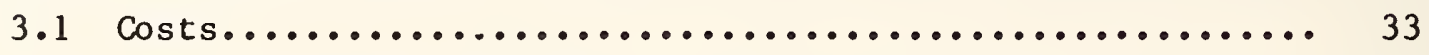

3.1.1 Purchase and Installation Cost Estimates........ 33

3.1.1.1 Component Cost Estimates............ 34

3.1.1.2 Financing and Tax Effects............ 48

3.1.1.3 Other Potential Costs of Purchase and Installation..................... 53

3.1.2 Operating, Maintenance, Repair and Replacement

Costs................................. 54

3.1.2.1 Operating Costs................... 54

3.1.2.2 Maintenance, Repair, and Replacement Costs 58 
3.1.3 Increased Property Taxes..................... 64

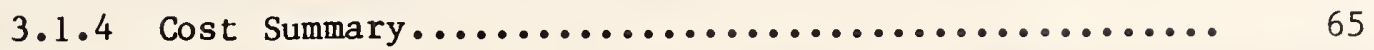

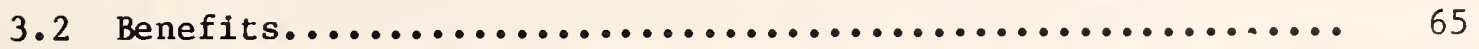

3.2.1 Reduced Risk of Death and Injury............... 67

3.2.2 Reduced Risk of Direct Loss.................. 75

3.2.3 Reduced Risk of Indirect Costs................. 78

3.2.4 Insurance Cost Savings.................... 82

3.2.5 Municipal Cost Savings in Fire Protection Services (Potential Property Tax Savings to the Homeowner)... 91

3.2.6 Governmental Incentives.................... 97

3.2.7 Other Potential Benefits.................... 99

3.2.8 Summary of Benefits Estimates................. 100

3.3 Case Study Results............................ 102

3.3.1 Base-Case Results......................... 102

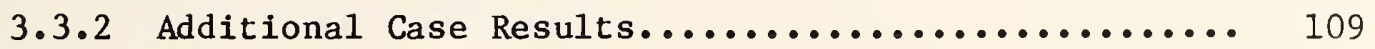

4. SUMMARY AND CONCLUSIONS............................ 115

SELECTED REFERENCES................................ 118

APPENDIX. Related Decision Models for the Builder/Developer and the Municipal Government....................... A-1 
1. Residential Sprinkler Systems......................... 3

2. System Design Used to Develop Component Cost Estimates........ 35

3. Assumed Annual Rate of Replacement of Sprinkler Heads During

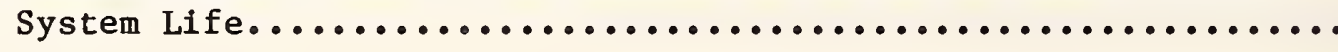

4. Determining the Area of the "New Development" for Which Fire Station Costs Will Be Avoided. 


\section{LIST OF TABLES}

1. Automatic Fire Sprinkler System with Copper Piping for a New, Two-Story, 2175 Square Foot Urban Dwelling: Cost

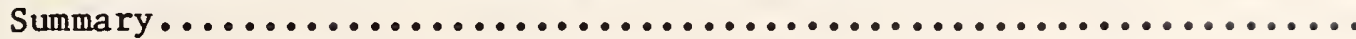

2. Automatic Fire Sprinkler System with Polybutylene Piping for a New, Two-Story, 2175 Square Foot Urban Dwelling:

Cost Summary

3. Cost Estimates for Residential Sprinkler Systems Based on System Costs as a Stated Percentage of House Construction

Costs..........................................

4. Cost Estimates for Residential Sprinkler Systems Based on Estimate Costs per Square Foot of Floor Area................

5. Summary of "Base Case" Costs for Residential Sprinkler

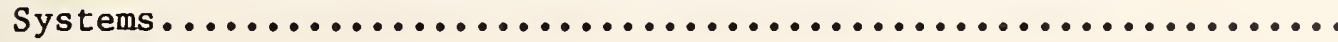

6. Estimated Impact of Sprinklers on Fire Deaths and Injuries in One- and Two-Family Houses.........................

7. Estimated Percentage Reductions in Fire Deaths and Injuries Attributable to Residential Sprinkler Systems...............

8. Estimated Impact of Sprinklers on Direct Fire Loss in Oneand Two-Family Houses.............................. 76

9. Estimated Indirect Costs of Residential Fires............... 79

10. Estimated Impact of Sprinklers on Indirect Fire Costs in

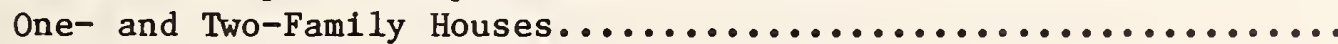

11. Estimated Property Insurance Rates in the U.S. for One- or

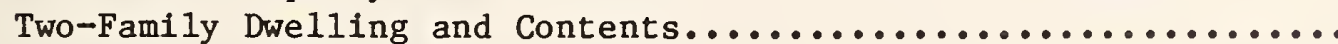

12. Summary of Benefits Estimates...................... 101

13. Summary of Data and Assumptions for Estimating Benefits for

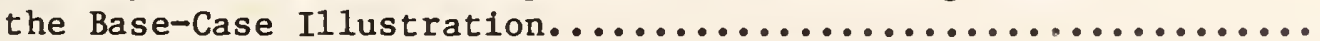

14. Summary of Data and Assumptions for Estimating Costs for the Base-Case Illustration.

15. Summary of Data and Assumptions for Other Illustrations....... 105

16. Summary of Economic Assumptions Used in Case Studies........ 106 


\section{LIST OF TABLES (CONTINUED)}

17. Base-Case: Net Benefits Calculation..................... 107

18. Base-Case: Break-Even Analysis.......................... 108

19. Summary of Net Benefits for Additional Hypothetical Case Studies... 110

20. Case II: Break-Even Values.............................. 114 


\section{EXECUTIVE SUMMARY}

Fire is the second most frequent cause of accidental death in U.S. homes. Well over a billion dollars of residential property loss results each year from residential fires. A potential for large savings exists in measures to reduce residential fire losses. In the face of budgetary pressures, a growing number of towns, cities, and individuals are seeking new approaches to fire mitigation which would offer effective protection at lower cost.

The purpose of this report is to develop and illustrate a methodology for assessing the economic feasibility of one new strategy for preventing residential fire losses: fast-response sprinkler systems. The focus is on modeling the investment decision as it affects an individual homeowner, but the interrelationship of this decision with that of builders and municipal governments is also discussed.

The report provides background on recent changes in residential sprinkler technology, the decision process by which sprinklers are installed in houses, and the role of economic analysis in addressing key issues related to diffusion of the technology. It develops a benefit-cost model for determining the expected value of net benefits as they would accrue to a homeowner who invests in a fast-response sprinkler system.

The benefit-cost model encompasses the future benefits to a homeowner of purchasing and installing a residential sprinkler system, as well as the Iife-cycle costs of owning the system over its expected life. Potential benefits consist primarily of reduced risk of death and injury from fire; 
reductions in risk of direct property losses and indirect losses such as medical and legal expenses, missed work, and cost of temporary shelter; possible savings in fire insurance costs; and possible reductions in local property taxes if the community collectively adopts sprinklers. Potential costs consist primarily of purchase and installation costs, adjusted for future resale value; operating, repair, replacement, and maintenance costs; and property taxes based on the value of the system. The model also takes into account financing costs and applicable income tax adjustments.

The model expresses the benefits of reduced fire losses in expected value dollars, reflecting the probability of fire occurring and of deaths, injuries, and direct and indirect losses resulting under alternative conditions of fire protection. Various components of system operating costs are also modeled as expected values, reflecting their functional relationship to the probability of fire occurring. All dollars of benefits and costs are taken over the entire period during which the homeowner is expected to have home sprinkler protection, and are adjusted to present value dollars so that they can be compared on a time-equivalent basis. Present value costs are subtracted from present value benefits to yield net present value benefits or losses.

The model assumes that the homeowner is risk neutral and seeks to maximize the net benefits obtainable from available funds. Hence, from an economic analysis point of view, positive net benefits from applying the model are interpreted to mean the homeowner will generally wish to purchase a system, while net losses 
indicate the contrary, apart from possible constraints such as income avallability and the size of the initial cash outlay requirements.

These assumptions constitute limitations of the model in that homeowners in actuality exhibit varying degrees of risk preference, have imperfect information, and in any case do not always behave as rational economic decisionmakers. Despite these limitations, correct application of the model can be expected to suggest tendencies of the homeowner to wish to buy or not to buy the system.

Parallel decision models for builders/developers and for local governments are also developed and presented in Appendix A of the report.

The report applies the decision model in a series of nine case illustrations, a11 of which are hypothetical in nature. The cases both demonstrate how the model is used and allow inferences to be drawn about the potential economic feasibility of sprinkler systems under the specified conditions.

A11 of the cases are based on (1) a system for a new, two-story, 2,175 square feet urban dwelling, that meets the requirements of NFPA 13D-1980 Standard; (2) an "average" probability of fire derived from aggregate U.S. fire statistics; (3) sprinkler system performance based on the results of recent laboratory and field tests of system effectiveness; (4) long-run average opportunity cost to the homeowner of 11.3 percent, including inflation and 
$6 \%$ excluding inflatiou, on alternative investments of equal risk; (5) a value per life of $\$ 0.50$ million and per injury of $\$ 0.02$ million; (6) a 40 percent marginal composite income tax bracket for the homeowner; (7) a system life of 30 years; (8) direct and indirect losses per fire corresponding to averages of sample loss data for the U.S. and (9) insurance rates and property tax rates and property tax rates corresponding to averages of sample data for the U.S.

The distinguishing features of each case and its "bottom line" estimate of net benefits or losses are sumarized briefly and may be compared in the following matrix. Break-even analysis is conducted to indicate the minimum or maximum changes in the values of key variables which would be necessary to equate benefits and costs under various conditions. For example, the results of the break-even analysis indicate that for Case I, any one of the following values would be sufficient to yield a break-even outcome, all other factors remaining the same: (1) a value of life of $\$ 2.6$ million (not discounted); (2) a probability of incurring a fire about 7 times the U.S. average rate; (3) a percentage reduction in the insurance rate about 5 times that assumed; and (4) an annual property tax reduction to the homeowner of about $\$ 100$. For Case II, examples of computed break-even values are the following: (1) a reduction in system costs of about 6 percent; (2) a probability of incurring a fire only slightly greater than that assumed; and (3) an average value of uninsured property loss per fire without sprinklers about 3 times larger than the estimated U.S. average dollar loss for houses without sprinklers. 


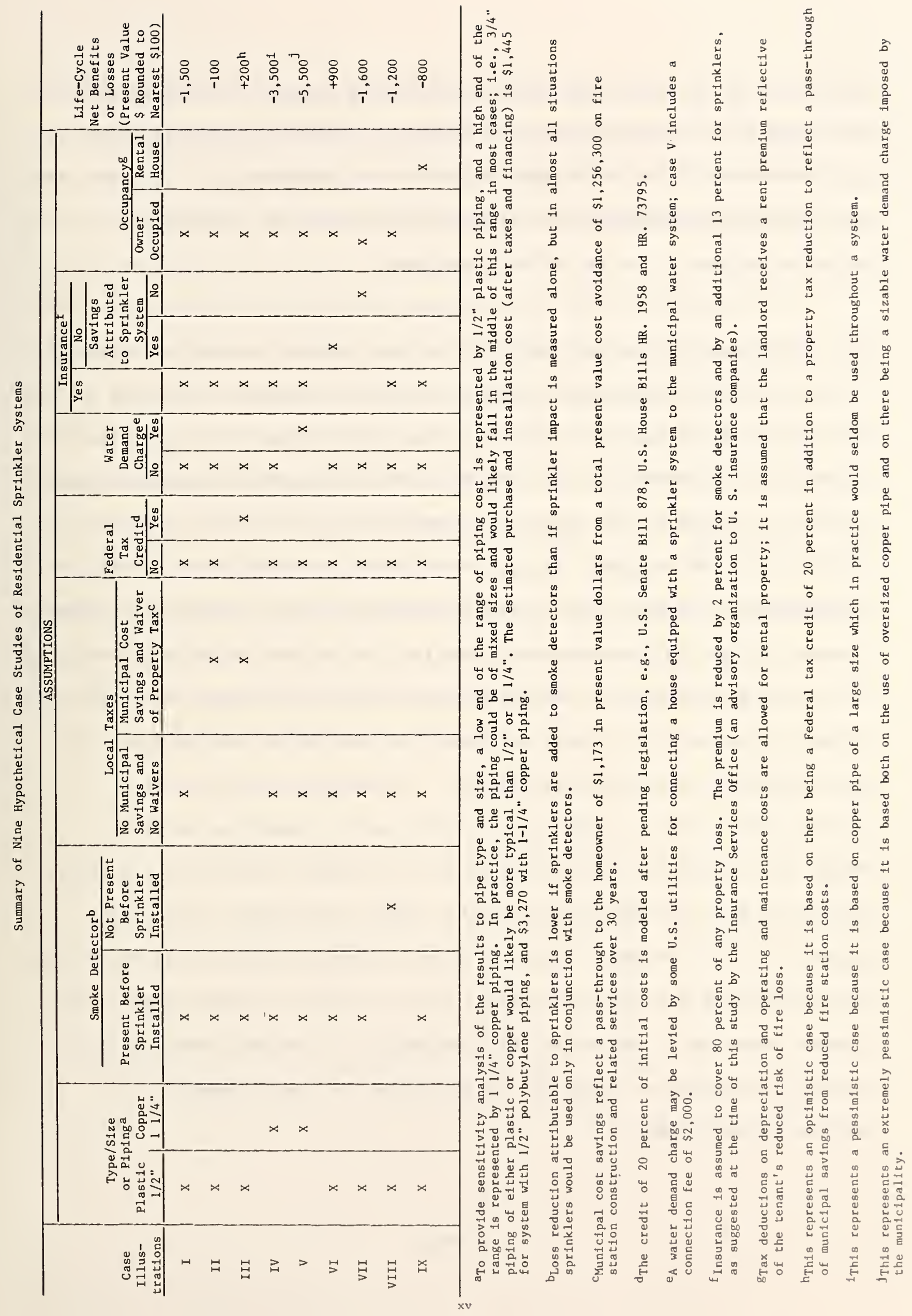


The results of the case studies are based on many assumptions, and it should be recognized that under different conditions, actual net benefits may be significantly different from those found in these illustrations. However, the cases provide some insight into the cost effectiveness of residential sprinkler systems in particular applications.

Some inferences that may be drawn from the case studies are the following: (1) The cost effectiveness of residential sprinkler systems is improved by code changes which allow the use of approved plastic pipe. (2) Sprinkler systems may be uneconomical for homeowners who independently purchase systems and who are subject to low-to-average probabilities of fire and risks of death, injury, and property loss; but they may be cost effective for homeowners subject to higher risk of fire and in greater peril of injury if fire occurs. (3) Sprinkler systems are more likely to be cost effective, other factors being the same, for homeowners who are part of a community of sprinkler users and who receive the benefit of attributed cost avoidance by local government or by the home builder. (4) Homeowners who live in localities with "water standby fees" or who use the commercial sprinkler systems are unlikely to have a cost-effective sprinkler system under average probabilities of fire and related death, injury, and property loss. Sprinkler systems are more likely to be cost effective when used in situations where additional protection is needed, such as a situation where the benefits of smoke detectors alone may not be attainable, for instance when occupants are hearing-impaired or otherwise incapacitated and cannot respond to a detector warning signal.

xvi 
The findings, though based on hypothetical cases, are helpful in identifying the following areas for further investigation: (1) the potential of municipal cost savings from sprinklered houses and the feasibility of corresponding local tax reductions, (2) the feasibility of cost/performance tradeoffs between sprinklers and housing density and between sprinklers and fireresistant construction methods and materials, (3) the availability of discounts on insurance premiums, (4) the practice of levying water demand charges on sprinklered houses, (5) approaches to lowering the costs of purchasing and installing sprinklers, (6) retrofit capability, (7) partial systems for fatality-prone areas of the house, and (8) benefits accruing to households with different behavioral and demographic characteristics and living in houses of different construction and age. The usefulness of the model as a decision tool for the homeowner can be increased by incorporating utility analysis. The models for builders/developers and for local government (Appendix) can be refined, tested, and used as aids to decision making. 



\section{INTRODUCTION}

\subsection{Background}

Residential fires cause more deaths, injuries, and property losses than any other kind of fire. Over 4,000 people were killed and another 14,000 injured in the approximately 522,000 reported fires that occurred in one- and two-family dwellings in the United States during 1981. More than 20,000 fire fighters were injured trying to extinguish these fires and rescue the occupants. Many of the injured suffered emotional damage. Over one and a half billion dollars of direct property loss resulted. I Indirect costs, such as the costs of temporary shelter, missed work, and legal, medical and funeral expenses, added nearly half a billion dollars of additional loss. 2

There is a potential for large savings through measures to reduce residential fire losses. This report is one step in the search for cost-effective solutions.

There are a number of strategles avallable for substantially reducing residential fire losses. These include enlarging the number and size of fire stations, carrying out public education programs to change human behavior in the built environment, increasing the fire resistance of building construction materials and furnishings through research and development and code and standards requirements, and installing protective systems within

1Fire in the United States, Fourth Edition, Federal Emergency Management Agency, Washington, D.C. 20472, September 1982.

2 Michael J. Munson and James C. Ohls, Indirect Costs of Residential Fires, Federal Emergency Management Agency, U.S. Fire Administration, Washington, D.C. 20421, July 1979. 
houses. However, these loss avoidance strategies can also be costly, and their costs add to the direct and indirect costs of fire losses to constitute the total cost of fires to the nation. As public resources for fire protection become increasingly limited, it becomes urgent for public officials, building designers, builders, and building owners to examine performance/cost tradeoffs among the alternative strategies for fire protection and to identify ways to minimize the overall cost of fires to individuals, communities, and to the nation.

The focus of this study is the development of a methodology appropriate for determining the potential cost effectiveness of one strategy for preventing residential fire losses: an automatic sprinkler system for installation in one- and two-family housing. An automatic sprinkler system consists of a configuration of water piping to which are connected automatic sprinkler heads, devices which open individually and automatically by operation of a heat-responsive releasing mechanism to discharge water in a specific pattern and density over a designated area. Sprinkler systems reduce losses to people and property by suppressing fire spread and either extinguishing the fire altogether or containing it to a smaller size. Thus sprinkler systems generally increase the time and available routes for occupants to escape fires, and they limit the amount of property damage.

To illustrate the sprinkler system being discussed, figure 1 shows in part A the diagram of a sample configuration of piping for a residential sprinkler system; part B illustrates a fast-response sprinkler head; and part C depicts a sample design schematic for a residential system. 


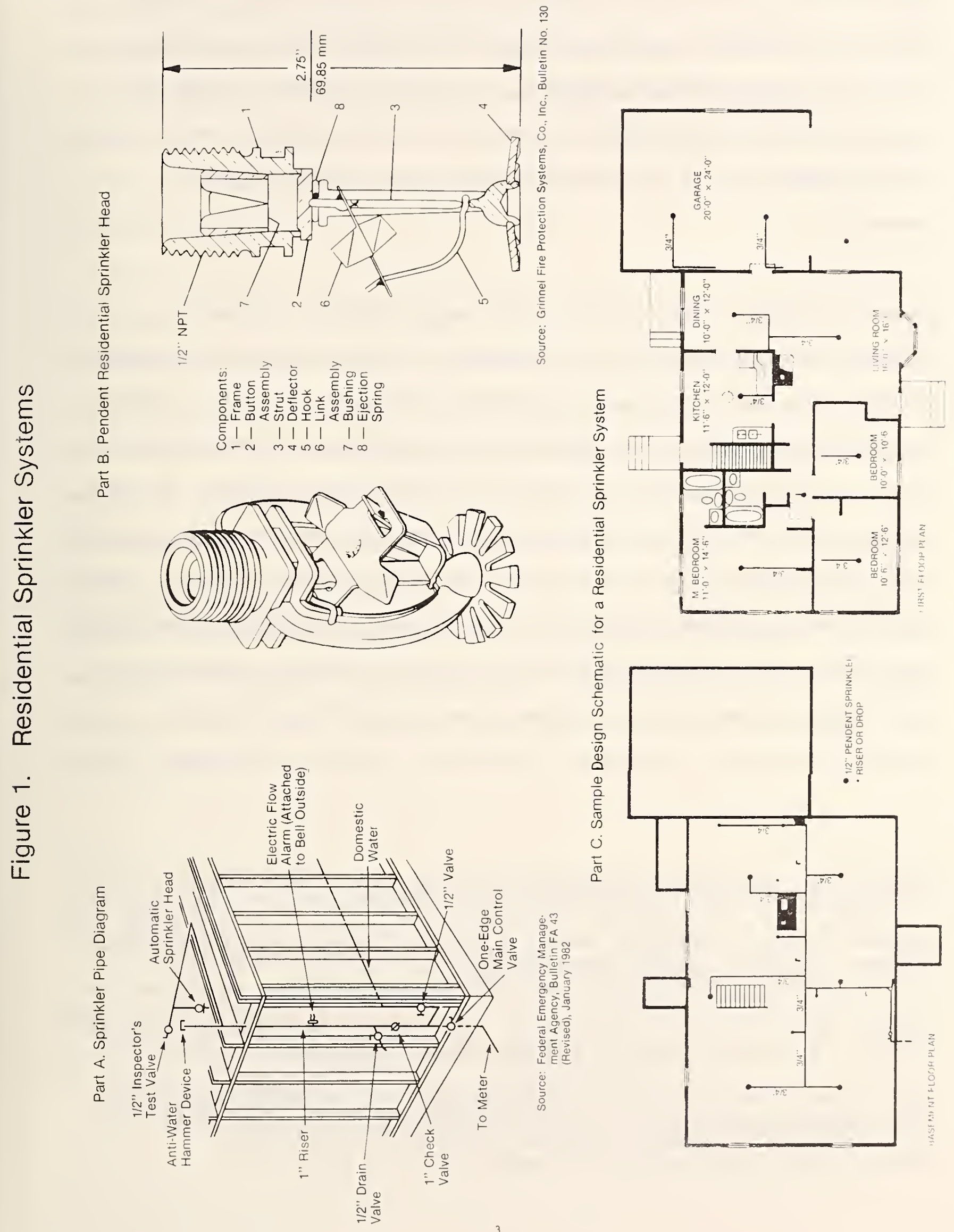


Sprinklers are a relatively new technology for residential use. A recent news report indicates that there are only about 2,000 houses in the United States which have sprinkler systems. 1 In contrast, sprinkler systems have long been widely used in commercial and institutional buildings, where their effectiveness in saving lives and protecting property has been well documented. 2

A major impediment until recently to the use of sprinkler systems in residences was the absence in the marketplace of systems specially engineered for home use. Faster sensing and activating devices are generally required for residential use than for commercial use because temperatures and gases rise to lethal levels faster in smaller rooms with lower ceilings. Moreover, differences in the typical distributions and nature of room contents cause the commercial sprinkler heads not to be well suited for residential use. Another problem has been system appearance. 3 In a survey, a significant proportion of homeowners voiced apprehension about the possible deleterious appearance in their homes of commercial-type systems. Fear of accidental discharge accounted for further reluctance of homeowners to install the systems. 4 The

1"Dousing Home Fires," The Washington Post, Saturday, July 10, 1982, p. E-1. 2 Federal Emergency Management Agency, Report to Congress on Fire Protection Systems: Detectors, Remote Alarm Systems, and Sprinklers, Washington, D.C.: U.S. Government Printing Office, June 1981).

3John J. Carlin III and Allen Stephens, "New Residential Sprinkler Standards Adopted," The International Fire Chief, February 1981, p. 23.

${ }^{4}$ Rolf Jensen \& Associates, Inc., Study to Establish the Existing Automatic Fire Suppression Technology for Use in Residential Occupancies, prepared for U.S. Department of Commerce, National Fire Prevention and Control Administration (Washington, D.C., August 1977), pp. 2-6. 
high cost of commercial-type systems, as well as the lack of an active distribution and service network for residential users, further discouraged their adoption for residential use. These impediments, together with a low level of public awareness of the fire problem--and, hence, low value assigned to fire protection systems--resulted in little activity in the residential sprinkler market.

Recent developments, however, suggest the need for a closer look at the potential for sprinkler systems in houses. Engineering developments include the production and marketing of a residential fast-response sprinkler head that activates 5 to 15 times faster than previously available commercial-type heads.1 It also has an improved water distribution pattern better suited to residential use. The likelihood of unnecessary activation of sprinkler heads beyond those in the immediate vicinity of a fire is reduced. 2 The threat of accidental discharge also has been reduced to extremely low levels: less than one-in-one million sprinkler heads per year compared to the roughly one-in-one hundred per year chance of having a home fire big enough to be reported to the fire department. 3

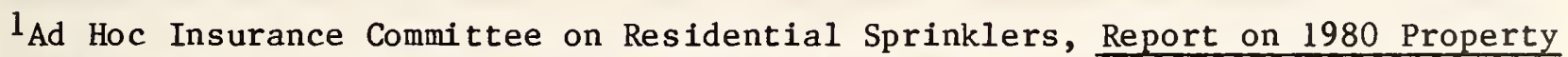
Loss Comparison Fires (Reprinted by Federal Emergency Management Agency, U.S. Fire Administration, National Fire Data Center, Washington, D.C.), November 1980 , p. 22 .

2"New Residential Sprinkler Standards Adopted," The International Fire Chief, February 1981, p. 23.

3 Federal Emergency Management Agency, Report to Congress. 
Design developments include the production of specially designed residential sprinkler systems which are less obtrusive and may meet aesthetic requirements for most houses. Design changes embodied in the revised 1980 National Fire Protection Association (NFPA) 13D Standard for residential sprinklers offer the potential of lower cost systems. The allowance of a combined piping system serving both sprinkler and domestic needs offers the potential of lower piping costs, and the allowance of a small-orifice sprinkler head reduces water flow requirements. Furthermore, although not explicitly listed as acceptable piping material, plastic piping--with its considerable potential for further cost reductions--is not precluded by the 13D Standard provided it be approved by a testing and inspection agency laboratory.1

Additional cost improvements are provided by the reductions in fire insurance that some companies are offering to homeowners with sprinklered houses. And, perhaps most importantly, communities that use residential sprinkler systems on a large scale may be able to reduce the costs of centralized fire protection.

Assessment of the technical performance and impact potential of the improved residential sprinkler system is underway, ${ }^{2}$ as are research efforts to improve

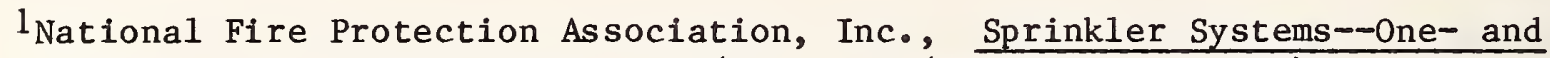
Two-Family Dwellings, 1980, ANSI/NFPA 13D (November 20, 1980).

2 Edward K. Budnick, Estimating Effectiveness of State-of-the-Art Detectors and Automatic Sprinklers on Life Safety in Residential Occupancies, National Bureau of Standards, NBSIR 84-2819, January 1984. 
further the engineering and design of the system.1 Benefit-cost studies are needed to estimate its current and potential economic feasibility.

\subsection{Purpose, Approach, Scope and Organization}

The purpose of this study is to develop a benefit-cost model for evaluating the economic efficiency of providing fire loss protection in one- and twofamily houses through the use of automatic sprinkler systems, and to demonstrate the use of the model through selected hypothetical case studies. The homeowner's perspective is taken in the model, because the homeowner is the ultimate decisionmaker and the elements of this model are fundamental to formulating other decision models. It is recognized, however, that builders/developers and municipal governments also play critical roles in the decision process; and those roles in relationship to the homeowner are discussed and requirements for additional decision models are treated.

The results of a benefit-cost study have a number of potential applications. Managers of government fire research programs, charged with reducing the total cost to the nation of residential fires, can use benefit-cost studies to identify fire research efforts with large potential payoffs, needed changes in building codes and standards, promising areas for coordinated decisionmaking, and information which can improve decisions of homeowners, developers, and communities regarding residential fire protection. City planners and managers seek information that will assist them in formulating economically efficient strategies for protecting the lives and property of citizens from destruction

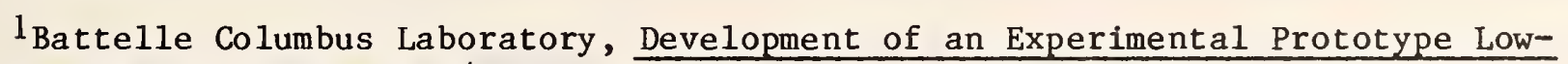
Cost Electronic Sensor/Actuator for a Residential Automatic Sprinkler Head, Report prepared for the Federal Emergency Management Agency, Undated. 
by fire. Architects, engineers, builders, and developers look for ways to deliver safe housing at affordable prices. And consumers seek information regarding the cost effectiveness and performance of new methods of fire protection.

The approach is, first, to outline the decision process, pointing out the interactions of homeowner decisions with those of builders/developers and government. Then a model of the individual homeowner's investment decision is developed. (Parallel models of builder/developer and local government decisions are also developed and presented in the appendix of the report.) Estimates of life-cycle benefits and costs to a hypothetical homeowner of installing and operating a sprinkler system are then made, based on U.S. average statistics and stated assumptions. Inferences are drawn from the results, and recommendations for further research are given.

The benefit-cost model employs conventional techniques of discounted cash flow analysis over an extended period of time, taking into account probabilistic estimates of sprinkler impact on fire losses. Break-even analysis is used to estimate maximum/minimum values of selected parameters to test conditions under which sprinkler systems are cost effective. Sensitivity analysis is performed by varying the data and assumptions in 9 case studies.

The benefit-cost model is generally applicable to the evaluation of sprinkler systems in all kinds of buildings. The illustration of the model in this study, however, is limited to new, one- and two-family dwellings. Retrofit applications to existing housing and applications to apartment buildings are not considered. The economic assessment is based on a level of sprinklers conforming to the ANSI/NFPA 13D-1980 Standard. 
The remainder of the report is organized in four major parts. In part 2, the decision process is discussed and the homeowner's decision model is developed. Part 3 contains the case studies. Part 4 contains a discussion of the findings, their implications, and suggestions for further research. An appendix concludes the report. The appendix develops models of system cost effectiveness from the prospective of the builder/developer and the municipal government, incorporating elements of the model of the homeowner's decision. 


\section{METHODOLOGY}

\subsection{The Decision Process}

The decision to include fire sprinkler systems in houses may be made by individual homeowners, by builders/developers who, responding to market demand, may offer them as a standard feature in speculative housing, or by municipal governments who may mandate their use through the code process. The investment decisions of individual homeowners and builders/developers may be influenced by costs and benefits, as well as related tax, code, and zoning provisions of 1ocal, State, and national governments. Some municipal governments may offer builders/developers and homeowners financial inducements to install sprinkler systems, predicated on a substitutability of self-protection strategies, such as sprinklers, for collectively provided fire protection strategies, such as fire stations. For instance, builders/ developers who agree to install sprinklers in speculative housing may be offered cost-reducing concessions by the local government in the form of zoning approvals for higher density housing, reduced code requirements for fire resistant construction, and lessened land set-aside requirements for fire lanes and stations. These cost reductions may increase the builder's profit, and/or lower housing costs to consumers. Hence, while public officials do not directly purchase and install residential sprinkler systems, their decisions can critically affect the investment decisions of those who do.

The ability of a community to reduce collectively provided protection services in exchange for self protection is dependent on the proportion of residents who invest in sprinklers. For example, the decision of only a few homeowners to install sprinklers affords 1ittle opportunity for changing housing densities or scaling down the size of fire stations. 


\subsection{Model of the Homeowner's Investment Decision}

For the purpose of this study, the homeowner's decision criterion for

investing in fire protection will be defined as maximizing the expected value of net benefits from the available budget. Thus, the evaluation model

captures both the expected value of benefits to be derived from a residential sprinkler system and the total life-cycle costs of owning, operating, maintaining, and repairing a system. Total present value benefits

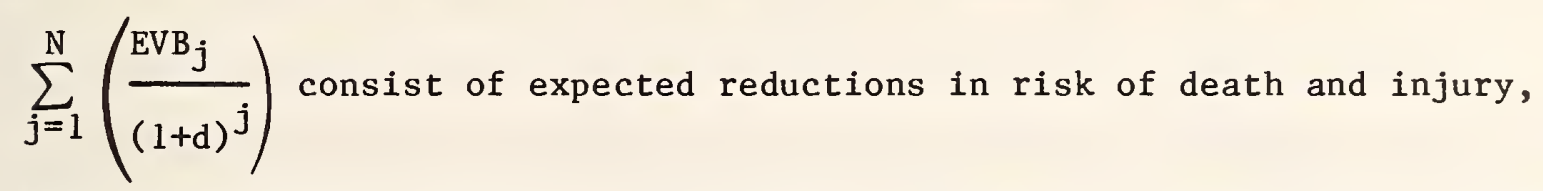
reductions in expected direct and indirect losses, and reductions in certain homeownership costs. Total present value costs $\sum_{j=1}^{N}\left(\frac{\mathrm{EVC}_{j}}{(1+d)^{j}}\right)$ are the sum of purchase and installation costs, operating, repair and maintenance costs, and other increased costs of homeownership attributable to the sprinkler system. Net present value benefits are the excess of benefits over costs, and net present value losses are the excess of costs over benefits.

The model can be represented as follows:

$$
E N B=\sum_{j=1}^{N}\left(\frac{E V B_{j}-E V C_{j}}{(1+d)^{j}}\right)
$$


where,

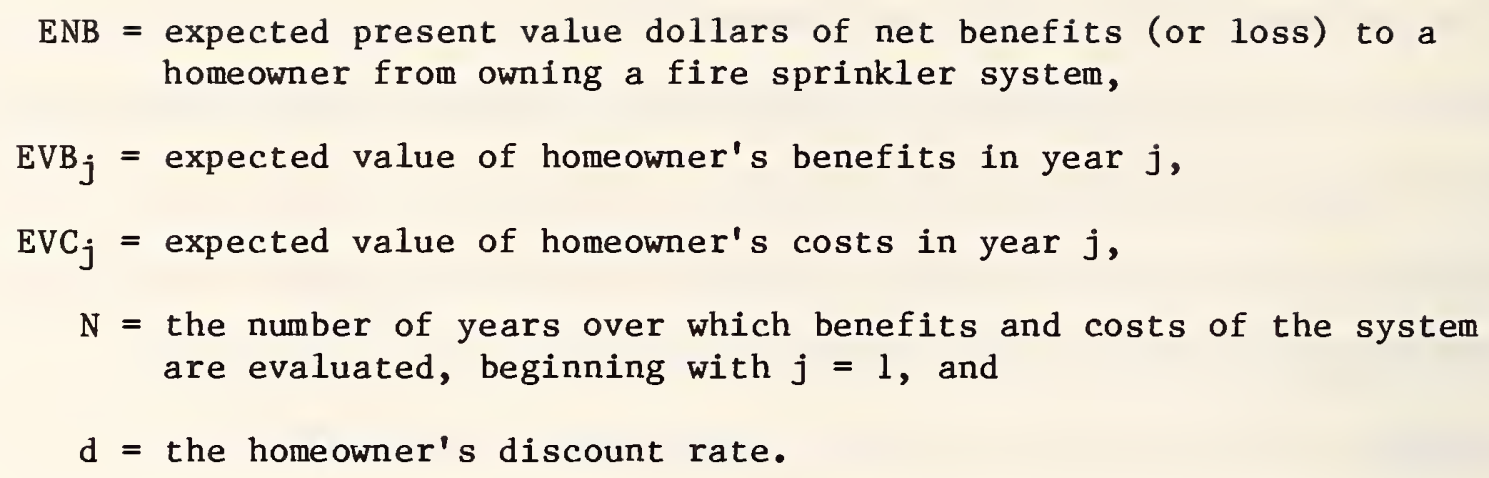

Dividing total benefits and total costs of the sprinkler system into major components, the model may be restated as follows:

$$
\begin{aligned}
& \sum_{j=1}^{N}\left(\frac{E V B_{j}}{(1+d)^{j}}\right)=\overline{D I}+\overline{P L}+\bar{C}+\overline{I N}+\overline{M T S}+\overline{O B} \\
& \sum_{j=1}^{N}\left(\frac{E V C_{j}}{(1+d)^{j}}\right)=\overline{P I}-\bar{S}+\overline{O P}+\bar{M}+\bar{P}+\overline{O C}
\end{aligned}
$$

and $\mathrm{ENB}=[\overline{\mathrm{DI}}+\overline{\mathrm{PL}}+\overline{\mathrm{C}}+\overline{\mathrm{IN}}+\overline{\mathrm{MTS}}+\overline{\mathrm{OB}}]-[\overline{\mathrm{PI}}-\overline{\mathrm{S}}+\overline{\mathrm{OP}}+\overline{\mathrm{M}}+\overline{\mathrm{P}}+\overline{\mathrm{OC}}]$ where,

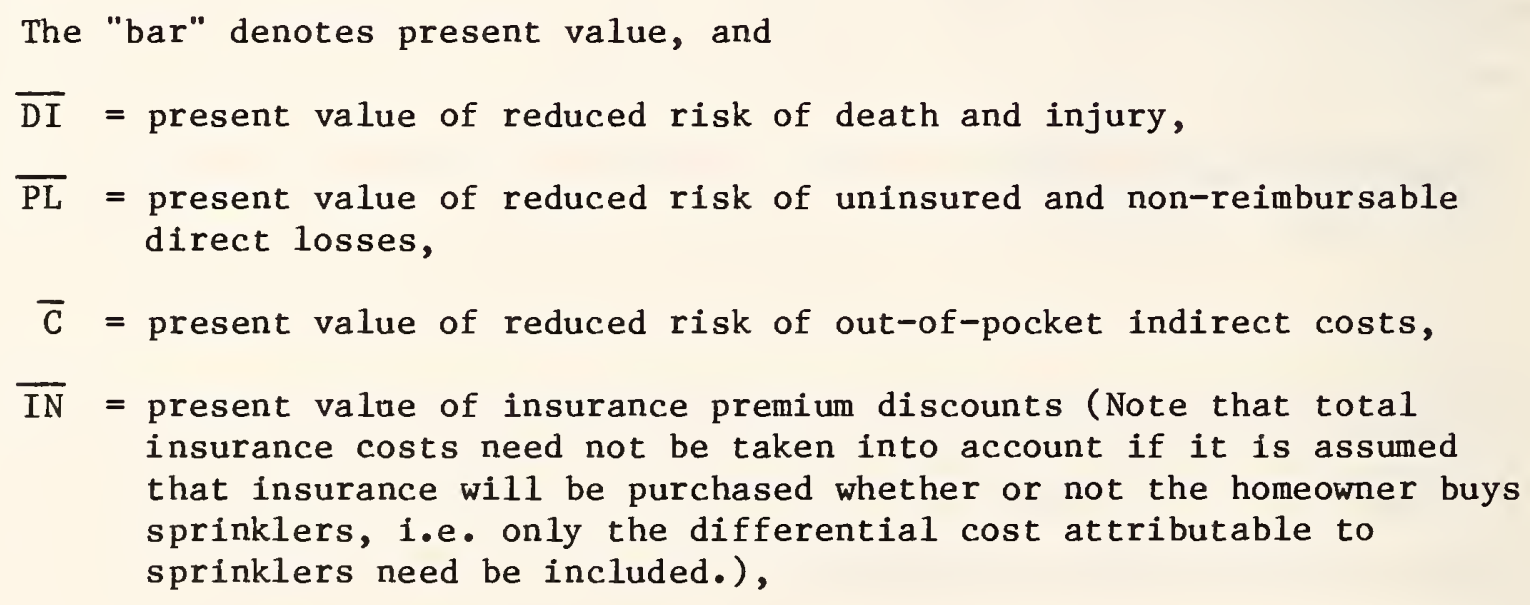
insurance costs need not be taken into account if it is assumed that insurance will be purchased whether or not the homeowner buys sprinklers, i.e. only the differential cost attributable to sprinklers need be included.), 


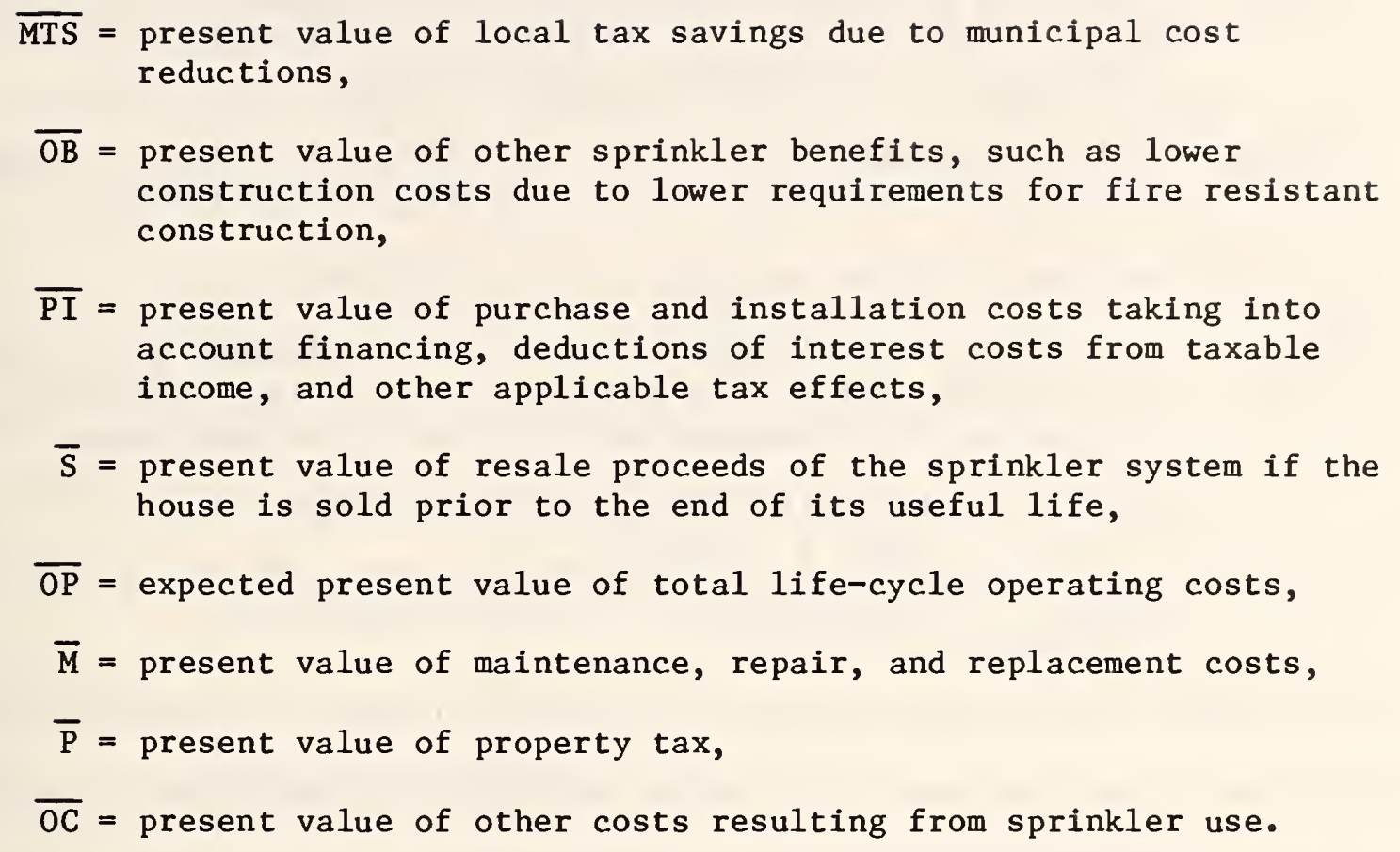

The formulas for calculating each of the above present value benefit and cost items are described below. The present value benefits of reduced risk of death and injury to the homeowner $(\overline{\mathrm{DI}})$ are modeled as follows:

$$
\overline{D I}=\left[\left(p(s, f) \cdot P(F \& D)_{p c} \cdot D V\right)+\left(i(s, f) \cdot P(F \& I)_{p c} \cdot I V\right)\right] \cdot\left(U P W_{d, n, e}^{*}\right),
$$

where,

$$
\begin{aligned}
& p(s, f)=\text { predicted fractional reduction in the probability of death } \\
& \text { given a fire, attributable to a sprinkler system, i.e., } \\
& p(s, f)=\frac{P(D \mid F)_{p c}-P(D \mid F)_{s}}{P(D \mid F)_{p c}}
\end{aligned}
$$

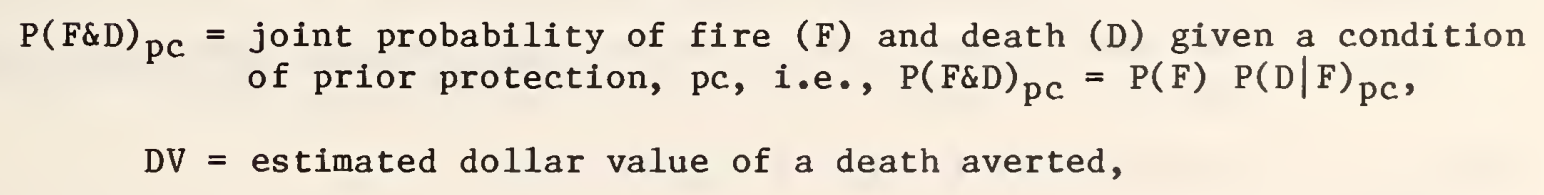




$$
\begin{aligned}
& i(s, f)=\text { predicted fractional reduction in the probability of an injury } \\
& P(F \& I)_{p c}=\text { joint probability of fire }(F) \text { and injury (I) given a condition } \\
& \text { of prior protection, } p c, i . e ., P(F \& I)_{p c}=P(F) P(I \mid F)_{p c} \text {, } \\
& \text { IV = estimated dollar value of an injury averted. } \\
& \mathrm{UPW}^{*} \quad=\text { a modified uniform present worth discount formula for finding } \\
& \mathrm{d}, \mathrm{n}, \mathrm{e} \text { the present value to the homeowner of a series of amounts } \\
& \text { escalating at a compound rate of e over } n \text { periods, where } \\
& \mathrm{UPW}_{\mathrm{d}, \mathrm{n}, \mathrm{e}}^{*}=\frac{(1+\mathrm{e})}{(\mathrm{d}-\mathrm{e})} \cdot\left[1-\left(\frac{1+\mathrm{e}}{\mathrm{I}+\mathrm{d}}\right)^{\mathrm{n}}\right] \text {, if } \mathrm{e} \neq \mathrm{d} \text {, and } \\
& \mathrm{UPW}^{*} \mathrm{~d}, \mathrm{n}, \mathrm{e}=\mathrm{n} \text {, if } \mathrm{e}=\mathrm{d} \text {. }
\end{aligned}
$$

This expression of the formula does not include the number of occupants of the house because it is developed for intended use with fire, death, and injury frequency data which implicitly reflect some average occupancy rate. To apply the model to cases with specific occupancy levels, it would be necessary to add an adjustment factor to account for occupancy levels smaller or larger than implied in national data averages.

The present value benefits of reduced risk of uninsured and non-reimbursable direct losses to the homeowner $(\overline{\mathrm{PL}})$ can be modeled as follows:

$$
\overline{\mathrm{PL}}=\ell(\mathrm{s}, \mathrm{f}) \cdot \mathrm{P}(\mathrm{F}) \cdot \mathrm{LD}_{\mathrm{pc}} \cdot \mathrm{UPW}_{\mathrm{d}, \mathrm{n}, \mathrm{e}}^{*}
$$

where,

$$
\begin{aligned}
\ell(\mathrm{s}, \mathrm{f})= & \begin{array}{l}
\text { predicted fractional reduction in direct uninsured and non- } \\
\text { reimbursable fire loss attributable to a sprinkler system, }
\end{array} \\
\mathrm{P}(\mathrm{F})= & \text { probability of fire occurring, } \\
\mathrm{LD}_{\mathrm{pc}=} & \text { estimated dollar value of direct uninsured and non-reimbursable } \\
& \text { loss per fire under prior protection state, pc, and }
\end{aligned}
$$


The present value benefits of reduced risk of out-of-pocket indirect costs $(\overline{\mathrm{C}})$, such as legal expenses, temporary shelter, and transportation, can be modeled as follows:

$$
\bar{C}=c(s, f) \cdot P(F) \cdot \mathrm{CV}_{\mathrm{pc}} \cdot \mathrm{UPW}_{\mathrm{d}, \mathrm{n}, \mathrm{e}}^{*},
$$

where,

$$
\begin{aligned}
c(s, f)= & \text { predicted fractional reduction in indirect fire costs, } \\
\mathrm{CV}_{\mathrm{pc}}= & \text { estimated average value of out-of-pocket indirect costs per } \\
& \text { fire under the prior protection state, } \mathrm{pc} \text {, and }
\end{aligned}
$$

$P(F)$ and

$\mathrm{UPW}_{\mathrm{d}, \mathrm{n}, \mathrm{e}}^{*}$ as defined previously.

The present value benefit of a discount in insurance premiums due to sprinklers $(\overline{\mathrm{IN}})$ can be modeled as follows:

$$
\overline{I N}=\operatorname{id}(i n \cdot I S) \cdot U P W_{d, n, e}^{*},
$$

where,

id = the fractional discount in premiums for homeowner's insurance for a sprinklered house,

in $=$ the insurance rate per $\$ 1,000$ of homeowner's coverage,

IS $=$ the amount of insurance coverage, in $\$ 1,000^{\prime} s$, and

$\mathrm{UPW}_{\mathrm{d}, \mathrm{n}, \mathrm{e}}^{\star}$ as defined previously.

(Equation 8 is elaborated upon in section 3.2 .4 to take into account the presence or absence of discounts related to smoke detectors and to distinguish owner-occupied and rental housing.) 
The present value benefits accruing to the homeowner from a passthrough of municipal reductions in costs of collective fire protection services $(\overline{\mathrm{MTS}})$ can be modeled as follows:

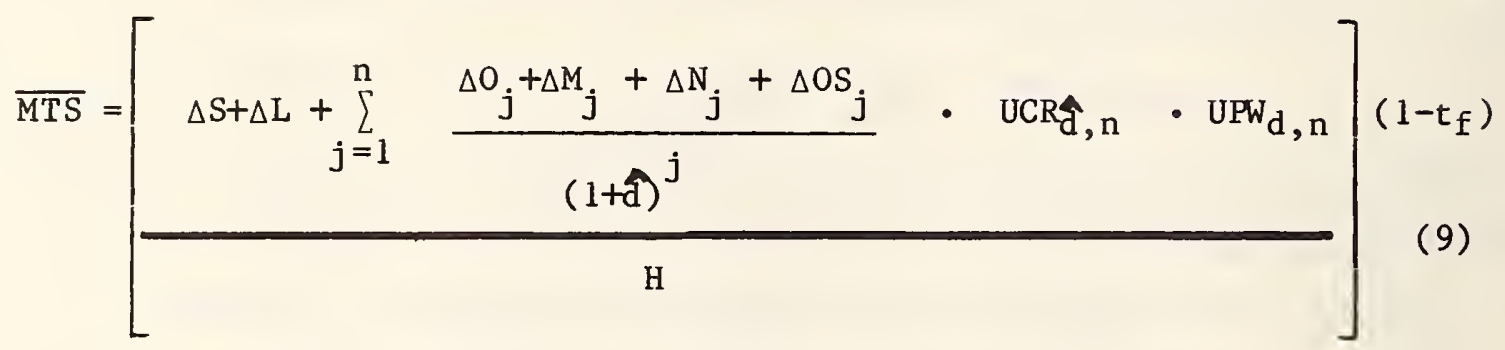

where,

$\overline{\text { MTS }}$ is modeled mainly for fire station cost reductions or cost avoidance, and

$\Delta$ denotes reduction in costs attributable to sprinklered houses,

$$
\begin{aligned}
\Delta \mathrm{S}= & \text { reduction in fire station structure costs, } \\
\Delta \mathrm{L}= & \text { reduction in fire station land costs, } \\
\mathrm{UCR}_{\mathrm{d}, \mathrm{n}=} & \text { uniform capital recovery formula for amortizing the structure } \\
& \text { land, operating, maintenance, staffing, and other costs at the } \\
& \text { estimated municipal discount rate, } \hat{d}, \text { over } n \text { years, } \\
\mathrm{UPW}_{\mathrm{d}, \mathrm{n}=} & \text { uniform present worth formula for finding the total present } \\
& \text { value over } \mathrm{n} \text { years of the amortized cost at the homeowner's } \\
& \text { discount rate, d, } \\
\mathrm{O}_{\mathrm{j}}= & \text { operating cost of the fire station in year } \mathrm{j}, \\
\mathrm{M}_{\mathrm{j}=}= & \text { maintenance cost of the fire station in year } \mathrm{j}, \\
\mathrm{N}_{\mathrm{j}}= & \text { staffing costs to provide fire protection services in year } \mathrm{j}, \\
\mathrm{OS}_{\mathrm{j}=} & \text { costs in year } \mathrm{j} \text { of other collective fire protection services, } \\
\mathrm{H}= & \text { number of households sharing the cost reductions or cost } \\
& \text { avoidances for collectively provided fire protection services } \\
& \text { and } \\
\mathrm{t}_{\mathrm{f}}= & \text { homeowner's marginal federal income tax rate. }
\end{aligned}
$$


Other present value benefits to the homeowner of having a sprinkler system $(\overline{\mathrm{OB}})$ might include lower construction and materials costs due to lessened code requirements for fire resistance, and lower land costs due to increased density allowances or smaller land set-aside requirements. These other potential benefits are neither modeled in detail nor included in the benefits estimates of this paper. As mentioned before, benefits represented by $\overline{\text { MTS }}$ and $\overline{O B}$ are likely to arise only if the individual homeowner buying a sprinkler system is part of a large, geographically significant bloc of sprinkler owners.

Purchase and installation costs can be adjusted to a present value basis ( $\overline{\mathrm{PI}})$, taking into account financing of the system as part of the house mortgage ${ }^{1}$, as we11 as related tax effects, as follows:

$$
\begin{aligned}
\overline{P I}= & (P I \cdot D P)+\left[P I \cdot(1-D P) \cdot\left(U_{C R}, \ell\right) \cdot\left(U P W_{d}, \ell / n\right)\right]-\sum_{j=1}^{n}\left[(t) \cdot\left(R P_{j}\right) \cdot(i) \cdot\left(S P W_{d}, j\right)\right]- \\
& \overline{T C}-\overline{D T S},
\end{aligned}
$$

where,

$$
\begin{aligned}
& \text { PI = contract cost of system purchase and installation, } \\
& \text { DP = fraction of PI placed as a downpayment, } \\
& \mathrm{UCR}_{\mathbf{i}, \ell}=\text { uniform capital recovery discount formula for amortizing the }
\end{aligned}
$$

The system is considered to be financed as part of the mortgage, since it is assumed to be installed in a newly constructed house. 


$$
\begin{aligned}
& t \text { = marginal composite (Federal, State, and local) income tax rate } \\
& \text { of the homeowner, } \\
& \mathrm{RP}_{\mathrm{j}}=\text { remaining principal outstanding on the loan in year } j \text {, where, } \\
& \text { for } j=1, R P_{1}=P I \cdot(1-D P) \text {, and for } j>1, R P_{j-1}-[(P I) \cdot(1-D P) \cdot \\
& \left.\left(U C R_{i, \ell}\right)-\left(R P_{j-1}\right) \cdot(i)\right] \text {, } \\
& i=\text { interest rate on the mortgage loan, } \\
& \mathrm{SPW}_{\mathrm{d}, \mathrm{j}}=\text { single present worth discount formula for finding the present } \\
& \text { value of the mortgage interest tax deduction in year } j \text {, } \\
& \overline{\mathrm{TC}}=\text { present value of any available governmental tax credits to } \\
& \text { purchasers of home sprinkler systems, } \\
& \overline{\mathrm{DTS}}=\text { present value of income tax savings due to depreciation of } \\
& \text { system acquisition costs if applicable (generally applicable } \\
& \text { only to rental housing). }
\end{aligned}
$$

The present value of resale proceeds realizable from selling the house prior to the end of the system's useful life $(\bar{S})$ are deducted from other costs, and can be modeled as follows: 1

$$
\overline{\mathrm{S}}=\mathrm{S}_{\mathrm{n}} \cdot \mathrm{SPW}_{\mathrm{d}, \mathrm{n}, \mathrm{e}}^{*},
$$

where,

$S_{n}=$ selling price of system at the end of the study period, where $S_{n}$ is adjusted for any outstanding balance on the mortgage loan, as well as applicable capital gains tax and, for a rental house, depreciation recapture tax, and

$\mathrm{SPW}^{*} \quad=$ single present worth formula, modified to include a constant $d, n, e$ rate of escalation over $n$ years, for use in finding the present value of resale at the end of year $n$.

The expected present value of life-cycle operating costs $(\overline{O P})$, consisting of water costs, water damage costs, and, for systems with pumps, electricity costs, can be modeled as follows:

$$
\overline{O P}=\overline{W C}+\overline{W D}+\bar{E} \text {, }
$$

$1_{\text {As }}$ sprinkler systems become more widely used, it may be possible to refine the estimation of resale price by incorporating a sprinkler variable into residential hedonic price indices to reflect sprinklers as one of the attributes which may influence housing prices. See, for example, Michael G. Ferri, "An Application of Hedonic Indexing Methods to Monthly Changes in Housing Prices, 1965-1975," AREUER Journal, Vol. 5, 1977, pp. 455-465. 
where,

$$
\begin{aligned}
\overline{\mathrm{WC}}= & \text { present value of water costs with the sprinkler system versus } \\
& \text { without it, } \\
\overline{\mathrm{WD}=} & \begin{array}{l}
\text { present value of water damage costs with the sprinkler system } \\
\text { versus without it, including costs from accidental discharge, }
\end{array} \\
\overline{\mathrm{E}}= & \text { present value of electricity costs, for operating the system, if } \\
& \text { applicable. }
\end{aligned}
$$

Water consumption costs and water damage costs will be incurred only if the system is activated. There are two main types of activation that may be considered: (1) intended activation induced by fire and (2) inadvertent, or accidental, activation. The latter is likely the only significant type to evaluate, because water consumption and water damage that would result from having the fire department extinguish a fire are likely to far outweigh that resulting from sprinkler activation.

The present value water consumption costs $\left(\overline{\mathrm{WC}}_{\mathrm{AD}}\right)$ for accidental discharge, though likely to be trivial in most cases, can be estimated using the following equation:

$$
\overline{\mathrm{WC}}_{\mathrm{AD}}=\mathrm{P}(\mathrm{DS} \mid \mathrm{NF}) \cdot\left(\mathrm{W} \cdot \mathrm{U}_{\mathrm{AD}}\right) \cdot \underset{\mathrm{d}, \mathrm{n}, \mathrm{e}}{\mathrm{UPW}^{*}} \cdot[1-(\mathrm{t} \cdot \mathrm{A})]
$$

where,

$$
\begin{aligned}
\overrightarrow{\mathrm{WC}}_{\mathrm{AD}}= & \begin{array}{l}
\text { present value of life-cycle water consumption cost for } \\
\text { accidental discharge, }
\end{array} \\
\mathrm{P}(\mathrm{DS} \mid \mathrm{NF})= & \text { conditional probability of discharge (DS) given no fire (NF) } \\
& \mathrm{P}(\mathrm{DS} \mid \mathrm{NF})=\frac{\mathrm{P}(\mathrm{NF} \& \mathrm{DS})}{\mathrm{P}(\mathrm{NF})},
\end{aligned}
$$




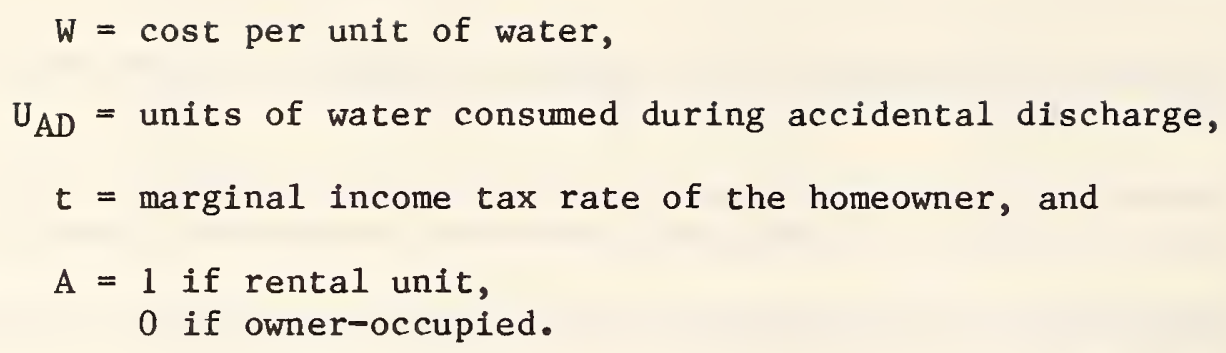

The water damage costs from accidental discharge $\left(\overline{\mathrm{WD}}_{\mathrm{AD}}\right)$ can be modeled in a comparable way as follows:

$$
\overline{\mathrm{WD}}_{\mathrm{AD}}=\mathrm{P}(\mathrm{DS} \mid \mathrm{NF}) \cdot \underset{\mathrm{d}, \mathrm{n}, \mathrm{e}}{\left(\mathrm{D}_{\mathrm{AD}}\right) \cdot \mathrm{UPW}^{*}} \cdot[1-(t \cdot \mathrm{A})]
$$

where,

$$
\begin{aligned}
\mathrm{D}_{\mathrm{AD}}= & \text { cost of repairing water damage in case of accidental discharge, } \\
& \text { and all other variables are as in equation (13). }
\end{aligned}
$$

The remaining element of operating costs is the present value of electricity costs, $\bar{E}$, for a system requiring a pump. This cost would be modeled similarly to $\overline{W C}_{\mathrm{AD}}$, except that electricity price and quantity would be substituted for the price and quantity of water, $W \cdot U$.

The present value of maintenance, repair, and replacement costs $(\bar{M})$ over the life cycle can be modeled as follows:

$\bar{M}=\left[\left(w_{m} \cdot h_{m} \cdot U P w_{d, n, e}^{*}\right)+\sum_{j=1}^{n}\left[\left(w_{r r j} \cdot h_{r r j}\right)+m_{r r j}\right] \cdot S P W_{d, j, e}^{*}\right] \cdot[1-(t \cdot A)]$, 
where,

$$
\begin{aligned}
\mathrm{w}_{\mathrm{m}}= & \text { wage rate per hour for routine maintenance, } \\
\mathrm{h}_{\mathrm{m}}= & \begin{array}{l}
\text { length of time in hours required for annual routine } \\
\text { maintenance, }
\end{array} \\
\mathrm{UPW}_{\mathrm{d}, \mathrm{n}, \mathrm{e}=} \text { uniform present worth discount formula modified to allow for } & \text { escalation of the wage rate at rate } \mathrm{e}, \\
\mathrm{w}_{\mathrm{rrj}}= & \text { wage rate per hour for repair and replacements in year } \mathrm{j}, \\
\mathrm{h}_{\mathrm{rrj}}= & \text { average length of time in hours required for repair and } \\
& \text { replacement in year } \mathrm{j}, \\
\mathrm{m}_{\mathrm{rrj}}= & \text { materials cost for repair and replacement in year } \mathrm{j}, \\
\mathrm{SPW}^{*} \mathrm{~d}, \mathrm{j}, \mathrm{e} & \text { single present worth discount formula modified to allow for } \\
& \text { escalation of prices at rate e, } \\
\mathrm{t}= & \text { marginal composite income tax rate of the homeowner, and } \\
\mathrm{A}= & 1 \text { if a rental unit, }
\end{aligned}
$$

The present value of increased property taxes $(\overline{\mathrm{P}})$ over the life cycle can be modeled as follows, based on a straight-line obsolescence rate:

$$
\bar{P}=\sum_{j=1}^{n}\left[P I \cdot(1-j / n) \cdot t_{p} \cdot S P W_{d, j, e}^{*} \cdot(1-t)\right],
$$

where,

$$
\begin{aligned}
\mathrm{PI}= & \text { contract purchase and installation cost of the sprinkler } \\
& \text { system, } \\
1-\mathrm{j} / \mathrm{n}= & \text { obsolescence factor, designed to result in a zero remaining } \\
& \text { tax base at the end of the system life, and } \\
\mathrm{t}_{\mathrm{p}=} & \text { effective property tax rate. } \\
= & \text { single present worth formula, modified to include a constant rate } \\
& \text { of escalation over } \mathrm{j} \text { years, for use in finding the present value } \\
& \text { of increased property taxes, and } \\
\mathrm{d}, \mathrm{j}, \mathrm{e} & \\
\mathrm{t}= & \text { marginal composite income tax rate of the homeowner. }
\end{aligned}
$$


The investment in the sprinkler system is estimated to be economically efficient if the present value of expected net benefits is positive, i.e. if $\mathrm{NB}>0$. The assumptions are that the investor is risk-neutral and other things remain equal. Other factors which may in fact not remain equal and which are not incorporated in the model include such things as valuation of aesthetic effects, consumer willingness to use new technologies, availability of system sales and system maintenance service in the marketplace, and local codes governing the use of sprinklers.

It should also be noted that an estimate of positive net benefits for sprinklers does not necessarily mean that homeowners will purchase them, even disregarding noneconomic considerations. Previous studies have shown, for instance, that a homeowner's decision to purchase analogous kinds of new housing technologies have depended critically on other economic factors such as the relative size of the initial cash outlay, the particular pattern of cash flows, or the perceived value of the investment as a status symbol.1

Further complicating the prediction of a homeowner's investment decision based on expected value results is variable risk preference. Homeowners may be risk-seeking, risk-indifferent, or risk-averse, as reflected in the shape of their utility functions. The criterion described above of maximizing the expected value of net benefits is relevant only if the decisionmaker's

$1_{\text {See, for example, Arthur J. Reiger, Marketplace Realities and Solar }}$ Economics. (U.S. Department of Housing and Urban Development Report, distributed by the National Solar Heating and Cooling Information Center), June 1978. 
utility function is linear, which it may or may not be. If it is not linear (i.e., the decisionmaker is not risk neutral), then preferred acts of investments can only be identified by converting expected values to expected utilities. This is possible for individuals, but there is no well-founded procedure for combining individual utility functions to obtain a group utility function, and, in fact, it may even be impossible to do so.l

A further limitation is the static nature of the model. It fails to capture fully the dynamic interactions of community, developer, and homeowner decisions. For example, community cost avoidance, which is modeled as a lower property tax to the homeowner, may simultaneously affect the conditional probabilities of fire loss and changes in insurance rates. Developer cost reductions from building more densely may alter the incidence of fire, and affect the homeowner in ways not captured by the model.

Some limitations are imposed not by the model itself but by the unavailability of data. It is difficult or impossible to obtain for all components of the model reliable and consistent data.

Despite these limitations, the above model can be helpful in predicting the market potential of residential sprinkler systems. The cost effectiveness of a new technology is an important determinant of its market rate of diffusion.

\footnotetext{
${ }^{1}$ See Arrow's impossibility theorem in K.J. Arrow, Social Choice and Individual Values, second ed., New Haven, Connecticut: Yale University Press, 1963.
} 
[Decision models for the builder/developer and of the municipal government are developed and presented in the appendix. These show how the elements of the models are interrelated.]

\subsection{Evaluation Techniques Used in the Model}

This section gives a brief reference to some of the techniques employed in the benefit-cost model for the convenience of the reader who is unfamiliar with the techniques.1 The reader who does not require this background may wish to go directly to section 3 .

Life-Cycle Approach. When first costs are relatively high and related benefits accrue over time, an economic evaluation method that employs a lifecycle approach, accounting for benefits and costs over the investor's time horizon, is generally appropriate. "Life-cycle costing" is a method for summing the stream of an investment's costs over time, where these costs are adjusted to a time-equivalent basis by a technique called discounting. ${ }^{2}$ The same type of approach can be applied to benefits, whereby the stream of benefits over time is also discounted and summed. By subtracting discounted

${ }^{1}$ For a general reference to benefit-cost analysis, see E. J. Mishan, CostBenefit Analysis, New York: Praeger, 1982 .

${ }^{2}$ For a further description of life-cycle costing, see Rosalie Ruegg and Harold Marshall, "Economics of Building Design," Solar Age, July 1981, pp. 22-27; Rosalie T. Ruegg, Stephen R. Petersen, and Harold E. Marshall, Recommended Practice for Measuring Life-Cycle Costs of Buildings and Building Systems, National Bureau of Standards, NBSIR 80-2040, June 1980; Rosalie T. Ruegg, Harold E. Marshall, and Porter Driscoll, "Life-Cycle Costing," Architectural Graphics Standards, 7th Edition, February 1981; Rosalie T. Ruegg, LifeCycle Cost Manual for the Federal Energy Management Program, National Bureau of Standards, Handbook 135 (Revised), May 1982; and Louis P. Clark, A LifeCycle Cost Analysis Methodology for Fire Protection Systems in New Health Care Facilities, National Bureau of Standards, NBSIR 82-2558, July 1982 . 
costs from discounted benefits, the net benefits (or net losses) measured in either present value or annual value dollars can be determined. By dividing discounted benefits by discounted costs, a benefit-cost ratio can be calculated. By accumulating future discounted benefits (less future discounted costs) on a year-by-year basis and comparing the result to the initial investment cost, the time to payback can be found. And, by solving for the interest rate that, when used in the appropriate discounting formulas, will equate benefits and costs, the internal rate-of-return on the investment can be determined.

Discounting 1

To an individual the value of a specific sum of money depends on precisely when it is to be received. Given the existence of interest rates and the opportunity of borrowing and lending, benefits in hand afford reinvestment opportunities, and it is generally preferable to receive benefits earlier than later. Costs deferred afford opportunities for interim uses of funds for other purposes, or the avoidance of borrowing costs; hence, it is generally preferable to defer costs. The "investment opportunity cost" can be accounted for by charging an interest rate for using resources over the relevant period of time. This procedure is usually called "discounting," and is accomplished through the use of compound interest formulas, or factors computed from the formulas, which can be used to convert differently timed cash flows to a time-equivalent basis, e.g., the present value, or annual value. The formulas and factors incorporate the investor's opportunity cost in terms of an

\footnotetext{
$1_{A}$ more detailed treatment of the discounting process may be found in Harold E. Marshall and Rosalie T. Ruegg, Simplified Energy Design Economics, National Bureau of Standards, NBS Special Publication 544, 1980, pp. 16-20.
} 
interest rate, usually referred to as the "discount rate." Discount rates may be expressed in either "nominal" or "real" terms. Nominal rates include both the opportunity cost of postponed receipts of money and the effects of inflation. Real rates reflect only the opportunity cost, not inflation.

Annual values and present values are equally valid ways of adjusting amounts to a common time basis for comparison and either can be used to compute measures of net benefits. Annual values express all costs and benefits as though they occurred in uniform yearly amounts over the study period, whereas present values express all costs and benefits as though they occurred in a lump sum at the beginning of the study period. Annual values and present values are time equivalents. This analysis expresses final dollar amounts as present values, but uses annual values in certain intermediate calculation steps.

Treatment of Inflation. A valid economic analysis requires that a common unit of measure be used for evaluating benefits and costs. This means that dollars of equal purchasing power (constant dollars) be used to indicate the various benefits and costs occurring over time, rather than dollars of changing purchasing power (current dollars). If benefits and costs are stated in current dollars, that is, in terms of the particular values of the dollar that are expected to hold in the years the benefits or costs occur, their value must be converted to constant dollars in a benefit-cost analysis. Current dollars may be converted to constant dollars prior to the discounting 
operation through the application of a price deflator index, followed by discounting with a real discount rate, that is, one that does not include purely inflationary or deflationary change. Alternatively, current dollars may be converted to constant dollars in the discounting operation through the use of a nominal discount rate, that is, one that does include a projection of the inflationary or deflationary rate of change. As a variation of the first approach, most prices and values used at the beginning of the study period may be assumed to remain the same over the study period when measured in constant dollars, and only those prices estimated to change at a rate faster or slower than the rate of general price inflation need be adjusted through the use of differential price escalation rates. Since benefits and costs are already in constant dollars when this approach is used, a real discount rate should be used.

The discounting factors used in the models are the Single Present Worth Factor (SPW), the Uniform Present Worth Factor (UPW), the Uniform Capital Recovery Factor (UCR); the Uniform Present Worth Factor modified to incorporate a constant rate of escalation (UPW*), and the Single Present Worth Factor also modified to incorporate a constant rate of escalation (SPW*). The SPW and $\mathrm{SPW}^{*}$ factors are used to convert a single future amount to an equivalent present value. The UPW and UPW* factors are used to convert amounts recurring over some specific number of periods to present values. The UCR factor is used to convert a present value to a series of uniformly recurring amounts. 
The incorporation of SPW* and UPW* factors in the model developed in section 2.2 allows for differential price escalation rates if the analyst chooses. However, in the case illustrations in this report all values are assumed to escalate at the general rate of inflation, i.e., a zero differential rate is used.

Expected Value Analysis. Even though the occurrence of future fires is not known with certainty, there is a known probability distribution based on fire statistics which can be used to calculate expected values of related benefits and costs.

In this study, sprinkler benefits in terms of reduced property losses, indirect costs, and fewer deaths and injuries are calculated as expected values by multiplying percentage loss reductions (based on sprinkler effectiveness test data) by estimated values of loss associated with a fire in the absence of sprinklers, and multiplying the result by the probability of fire occurrence. The expected value of benefits in future years can be discounted to a present value equivalent by multiplying each year's expected value by the appropriate single-amount discount factor and summing across years or, if annual benefits are uniform or change at a constant rate, simply by multiplying the initial year's expected value by the appropriate UPW or UPW* factor. 
Sensitivity Analysis. By testing the responsiveness of benefit-cost results to variations in values assigned to different parameters, sensitivity analysis allows the identification of those parameters that are most important to the economic success of residential sprinklers. Additionally, sensitivity analysis is useful in assessing the consequences of uncertainty in data and in assumptions. It does not tell the decision maker the values that should be used, but it shows the impact of using different values.

Break-Even Analysis. Another approach that can provide useful information to decisionmakers in the face of uncertainty is break-even analysis. By setting benefits equal to costs, and leaving the value of one of the parameters unspecified, it is possible to solve for the minimum or maximum value which it must take in order for the system to be minimally cost effective.

\subsection{Economic Parameters and As sumptions}

This section discusses establishing values for the discount rate, inflation rate, real price changes, system life, study period, and tax rates.

The discount rate, a compound rate of interest used to convert benefits and costs occurring at different times to a common time, should reflect the investor's opportunity cost of capital. The higher the rate, the lower will be the present value of future costs and benefits. 
There is no single rate that is appropriate for all investors, but in a "generic type" of study such as this, it is desirable to choose a rate that will be representative "on the average" for the subject group of investors. There is a wide disparity among homeowners as to their discount rate, since at any given time some will be in net debt positions at interest rates ranging from low to high, and some will be in credit positions at yields also ranging from low (in some cases yields may be negative after taxes and inflation) to high.

As background to selecting a discount rate for the case studies, the average of real, after-tax rates of return to investors in all grades of nonfinancial common stock and long-term corporate bonds over the 1947-1975 period was examined, and was found to be 7 percent.1 Additionally, discount rates by income class, as derived by Hausman for individuals purchasing energy-using durable goods, were considered. In the late 1970's, the implicit discount rates for homeowners with incomes between $\$ 35,000$ and $\$ 50,000$ ranged from 5.1 percent to 8.9 percent. 2 With this general guidance, a rate of 6 percent was selected for use in the case studies. The 6 percent rate is defined as a real rate, after taxes.

${ }^{1}$ See description of approach and data analysis in Rosalle T. Ruegg, et. al., Economic Evaluation of Solar Energy Systems in Commercial Buildings; Methodology and Case Studies, National Bureau of Standards NBSIR 82-2540, pp. 87-89, as based on historical trends in rates of return to investors published by Daniel M. Holland and Steward C. Meyers, Trends in Corporate Profitability and Capital Costs, WP 937-77, Alfred P. Sloan School of Management (Cambridge, Mass: Massachusetts Institute of Technology), 1977.

2 Jerry A. Hausman, "Individual Discount Rates and the Purchase and Utilization of Energy-Using Durables," Be11 Journal of Economics, Vol. 10, No. 1, 1979. 
Because there is little basis for projecting differential rates of inflation for most of the categories of costs and benefits of sprinkler systems, most of them are assumed to inflate at the rate of general price inflation. The rate of general price inflation is set at 5 percent per annum. In the case of interest expense and depreciation expense--both items which are based on historical costs and are not variable with inflation (variable rate mortgages are not treated)--it is necessary to convert the costs to their constant dollar equivalents. This is done by discounting the nominal cash flows with a nominal discount rate which is adjusted to reflect the assumed 5 percent inflation rate. The inflation-adjusted, market rate is 11.3 percent; i.e., $0.06+0.05+(.06)(.05)=0.113$ or 11.3 percent. 1

The study period is the length of time over which costs and benefits from the sprinkler system are calculated. The length of the study period need not coincide with the length of the system life. The model allows for system replacements and resale or disposal values to reconcile the two. However, for the purpose of the case studies, the study period is selected to coincide with the assumed system life.

There is no empirically validated life for fast-response residential sprinkler systems. However, system components are similar to components for which there is some experience with durability. Plumbing systems in houses generally have long lives; sprinkler apparatus in commercial buildings appear to have relatively long lives. A study period and system life of 30 years are assumed.

lThe market rate is equal to the real rate plus the inflation rate plus the product of the two rates. 
Marginal Federal income tax rates range among homeowners from a low of about 10 percent to a high of about 50 percent. To the Federal income tax rate can be added any applicable State and local income tax rates, taking into account the deductibility of one from the other. For the case studies, a composite marginal income tax rate of 40 percent is used to evaluate tax effects.

Effective property tax rates in the U.S. range from about 0.82 percent to 7.46 percent. 1 The national average effective rate in U.S. cities of 2.15 percent is used in the case studies to evaluate property tax effects.

${ }^{1}$ U.S. Bureau of the Census, Statistical Abstract of the United States 1980, Washington, D.C. 


\section{SELECTED APPLICATIONS}

The purpose of this section is to demonstrate the use of the model in selected applications. The model serves as a framework for data collection and estimation. The data are then applied to a series of hypothetical case studies pertaining to new single-family houses in the U.S. under specified conditions of fire risk, property values, loss rates and construction and system costs.

\subsection{Costs}

This section discusses approaches for estimating values of the various cost components, develops sample costs for the selected applications, and shows the conversion of estimates to present value dollars. Emphasis is placed on estimating purchase and installation costs, and three approaches are taken to developing those estimates. (Research and code enforcement costs are not considered.)

\subsubsection{Purchase and Installation Cost Estimates}

The principal approach taken to estimating purchase and installation costs is the component method of construction cost estimating, whereby itemized estimates are developed for the costs of piping, valves, fittings, sprinkler heads, and other elements of sprinkler systems for new one- and two-family houses.

The results are compared with estimates derived by expert opinion, application of "rule-of-thumb" guidelines, and by update of a previous cost study. 


\subsubsection{Component Cost Estimates}

To employ the component cost estimating method, which is in effect a "custom" approach, it is necessary to have a description of the main physical characteristics of the system. Figure 2 illustrates the physical basis used to develop the component cost estimates. The figure shows the floor plan and schematic of a sprinkler system for a two-story, colonial-style house with basement. The house has a total floor area of 2,175 square feet, with 1,975 square feet of the area protected by sprinklers. The level of protection corresponds to the minimum requirements of the NFPA 13D-1980 Standard. Exceptions to required coverage allowed by the Standard are employed. These exceptions include: bathrooms not exceeding 55 square feet with noncombustible plumbing fixtures; small closets of which the least dimension does not exceed 3 feet, the area does not exceed 24 square feet, and the walls and ceilings are surfaced with noncombustible materials; open attached porches; and entrance foyers which are not the only means of egress. As required by the Standard, maximum coverage for the individual sprinkler heads is 144 square feet, the sprinklers are no more than 6 feet distant from walls and partitions and no more than 12 feet distant between one another on or between pipe lines; and the distance between sprinklers within a compartment is not less than 8 feet. The sprinkler system is assumed to be a wet system and areas with piping are assumed to be not subject to freezing.

Houses vary considerably in size and layout; water pressure conditions vary; local building code requirements differ; and the NFPA 13D-1980 Standard allows leeway in pipe configuration and materials. Therefore, it is 


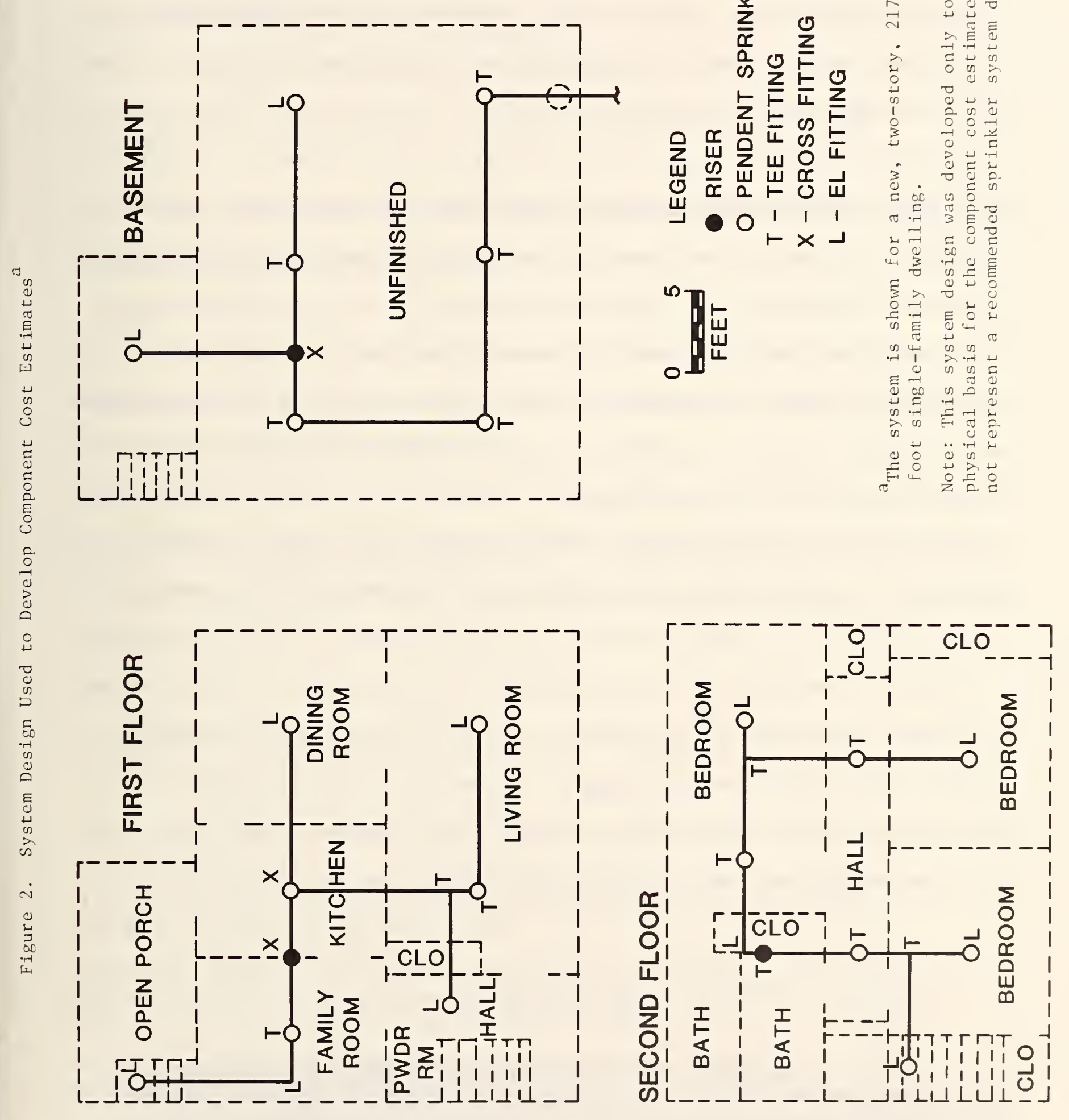


impossible to specify in detail a "universal" residential sprinkler system. The system depicted in figure 2 is intended only as a basis for developing approximate reference costs. It is in no way offered as a recommended design. It should be noted that costs of actual systems may differ substantially from those developed here, reflecting not only differences in system size and design but also in regional costs.

Reflecting the potential variation in requirements for pipe size, low- and high-cost estimates are developed for the sample system depicted in figure 2 , based on the smallest ( $1 / 2$ inch) and the largest ( $11 / 2$ inch) diameter pipe which would ever likely be used in a system ( $1 / 2$ inch would generally be used only for supply pipe diameters). In practice, a combination of pipe sizes might be used, the choice depending on design configuration, local water pressure factors and code requirements. Pipe $3 / 4^{\prime \prime}$ or 1 inch in diameter would be more typical than the boundary estimates used in the study. Estimates based on $11 / 4$ inch pipe are also included for comparison with a previous study. 1

The sample cost estimates are developed for both copper $M$ and polybutylene piping. The copper provides a high end estimate and the polybutylene, the low end of the range for piping costs. Copper pipe is currently most widely used for plumbing systems, but polybutylene pipe offers the potential of

\footnotetext{
$1_{A}$ comparison is made with cost estimates (updated by this Study) developed by Rolf Jensen and Associates, Inc., Study to Establish the Existing Automatic Fire Suppression Technology for Use in Residential Occupancies, A Summary Report, August 1977.
} 
substantial cost reductions and is currently being used in residential sprinkler systems. 1 Comparative tests for plumbing systems found total installed labor and materials costs to be about 44 percent less for polybutylene than for copper pipe. 2

Estimated costs for a two-family dwelling are developed by applying a multiplier to the single-family estimates. The procedure treats a duplex as two end-unit town houses and uses an adjustment multiplier from the MEANS Building Construction Cost Guide 1982.

Costs reflect assumptions of average construction quality, and are based on average materials prices and labor rates for 30 major U.S. cities. The labor rates include overhead and profit. 3

Table 1 gives component cost estimates based on copper piping. The estimated total system cost for a single-family dwelling ranges from a low of $\$ 2,466$ for a system with $1 / 2$ inch diameter pipe to a high of $\$ 3,935$ for $11 / 2$ inch diameter pipe. The total cost of a system using $11 / 4$ inch pipe is estimated at $\$ 3,724$.

Interview with Kathy Vernot, Director, Life-Safety Division, Central Sprinkler Corporation, November 1981.

2 Results of a study performed by the National Association of Home Builders, as cited in Shell Chemical Company Performance Report, SC:550-81, September 1981 .

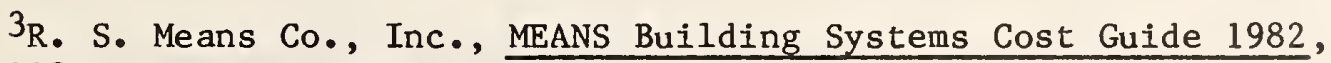

118 Construction Plaza, Duxburg, MA. 


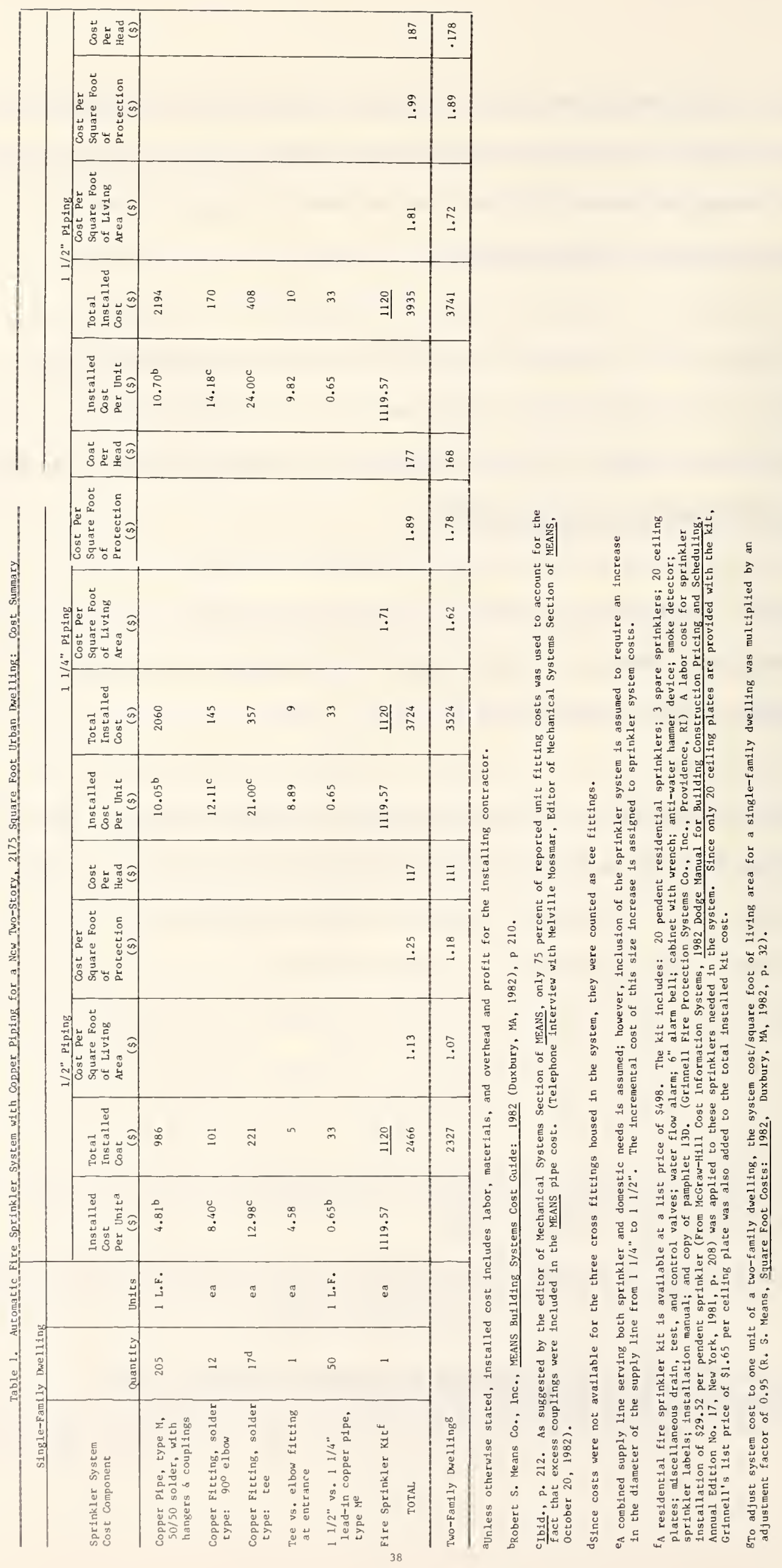


Expressed as cost per square foot of living area, the low end of the range is $\$ 1.13$ and the high $\$ 1.81$. Expressed as cost per square foot of protected area, the low end is $\$ 1.25$ and the high $\$ 1.99$. The estimated average cost per sprinkler head ranges between $\$ 117$ and $\$ 187$. The fire sprinkler kit comprises from 28 to 45 percent of estimated total system cost, depending on pipe diameter.

For one unit of a two-family dwelling, where each unit is equal in size to the single-family dwelling the estimated total cost of a copper-pipe system ranges from $\$ 2,327$ to $\$ 3,741$.

The top part of table 2 gives component cost estimates based on the use of polybutylene pipe. The lower part of the table gives estimates based on polybutylene pipe derived by applying a fixed 44 percentage cost reduction to the estimates for copper piping.

The total cost of a single-dwelling sprinkler system using plastic pipe is estimated to range from a low of $\$ 1,718$ (installed cost based on individual components computation) for $1 / 2$ inch pipe to a high of $\$ 2,697$ (installed cost based on percentage computation) for $11 / 2$ inch pipe. The estimated cost per unit of living area for the single-family dwelling ranges from a low of $\$ 0.79 / \mathrm{sq} . \mathrm{ft}$. for $1 / 2$ inch pipe to a high of $\$ 1.25 / \mathrm{sq}$.ft. for $11 / 2$ inch pipe. The unit cost of protected area ranges from a low of $\$ 0.87 /$ sq.ft. for $1 / 2$ inch pipe to a high of $\$ 1.37 / \mathrm{sq} . \mathrm{ft}$. for $11 / 2$ inch pipe. The cost per sprinkler head for the single-family dwelling ranges from $\$ 82$ to $\$ 129$. Cost of the system for one unit of a two-family dwelling equal in size to the single-family dwelling is estimated to be 5 percent less. 


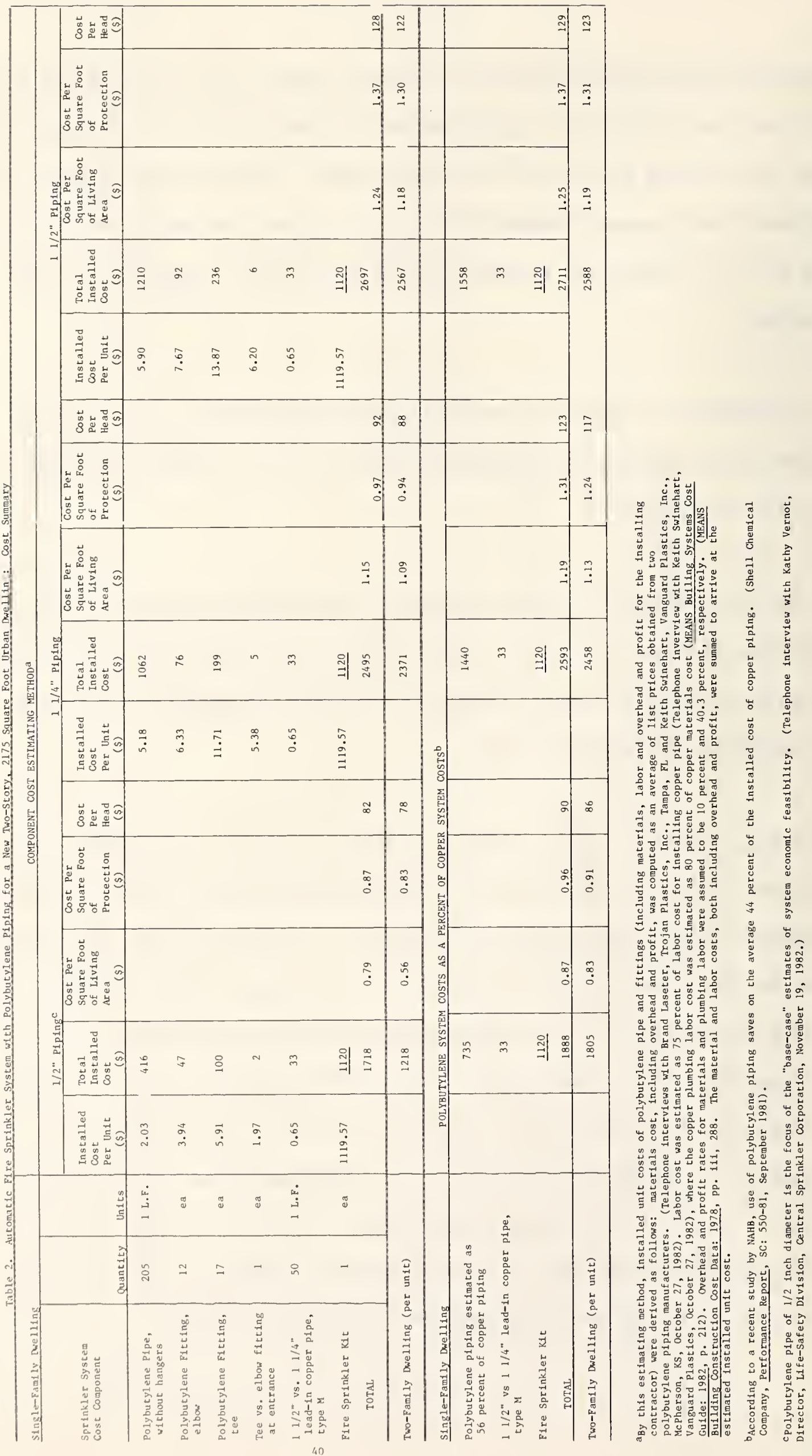


It should be noted that the cost differential between copper and plastic pipe is sensitive to the cost of copper. Prior to 1981-1982, plastic pipe would have offered a larger margin of savings over the cost of copper pipe than at the time of this study.

Let us now compare the above component cost estimates with estimates developed by the two other approaches, beginning with cost estimates suggested by people knowledgeable in the field. Fire protection consultants interviewed for a recent newspaper article suggested a cost range of $\$ 1,700$ to $\$ 2,000$ for a sprinkler system for a "typical" 2,000 square-foot dwelling.l This estimate brackets the component cost estimate of table 2 based on $1 / 2$ " polybutylene piping.

In 1979, the president of the National Automatic Sprinkler and Fire Control Association estimated that a sprinkler system could be installed in a one-or two-family dwelling unit of between two-to-three thousand square feet for less than $\$ 1,200$, of which about $\$ 500$ would be for materials and about $\$ 600$ for labor. He further estimated that about $\$ 100$ of the total materials cost would be for sprinkler heads and related components supplied by sprinkler manufacturers. 2 Updated to 1982 dollars, these figures become $\$ 1,500$ for the

1"Dousing Home Fires," The Washington Post, July 10, 1982, p. E-1.

2Edward J. Reilly, "Residential Sprinkler Systems--Where Do We Go From Here?" (Paper presented at the Fourth Annual Conference on Low Cost Residential Sprinkler Systems, sponsored by the U.S. Fire Administration, September 25-26, 1979), p. 3. 
total system cost, and $\$ 600$ and $\$ 700$ for materials and labor, respectively. 1 This estimate is about $\$ 200$ less than the component cost estimate for $1 / 2$ " polybutylene piping developed here.

Estimates as to how much it should cost to purchase and install a sprinkler system, expressed as a percentage of the construction cost of the house in which it is installed, range from about 1 percent to 2 percent of the cost of the house. 2 For "typical" commercial, industrial, storage, and institutional buildings, sprinkler system costs have been reported to represent about 1.5 percent of total construction costs. 3

Table 3 shows cost estimates for residential sprinkler systems based on sprinkler costs as $1.0,1.5$, and 2.0 percentages, respectively, of estimated house construction costs. The cost estimates are derived by applying the stated percentages to 1980 and 1981 sales prices of new, private, one-family houses, multiplied by a factor of 0.8 to adjust for estimated average land cost. The first two columns of the top portion of the table give the 1980 and 1981 median and mean sales prices. The last three columns of the table give the estimated costs.

$1_{1979}$ cost data are updated to 1982 prices by multiplying them by a factor of 1.228 developed from the Department of Commerce Composite Construction Cost Indexes for 1979 and April 1982, as reported in U.S. Department of Commerce, Bureau of Industrial Economics, Construction Review, Vol. 28, No. 3, May/June 1982.

${ }^{2}$ See, for example, "Dousing Home Fires," The Washington Post, and John J. Carlin, III and Allen Stephens, "New Residential Sprinkler Standards Adopted," The International Fire Chief, February 1981, p. 23.

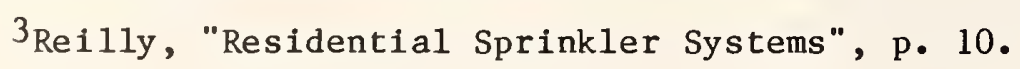




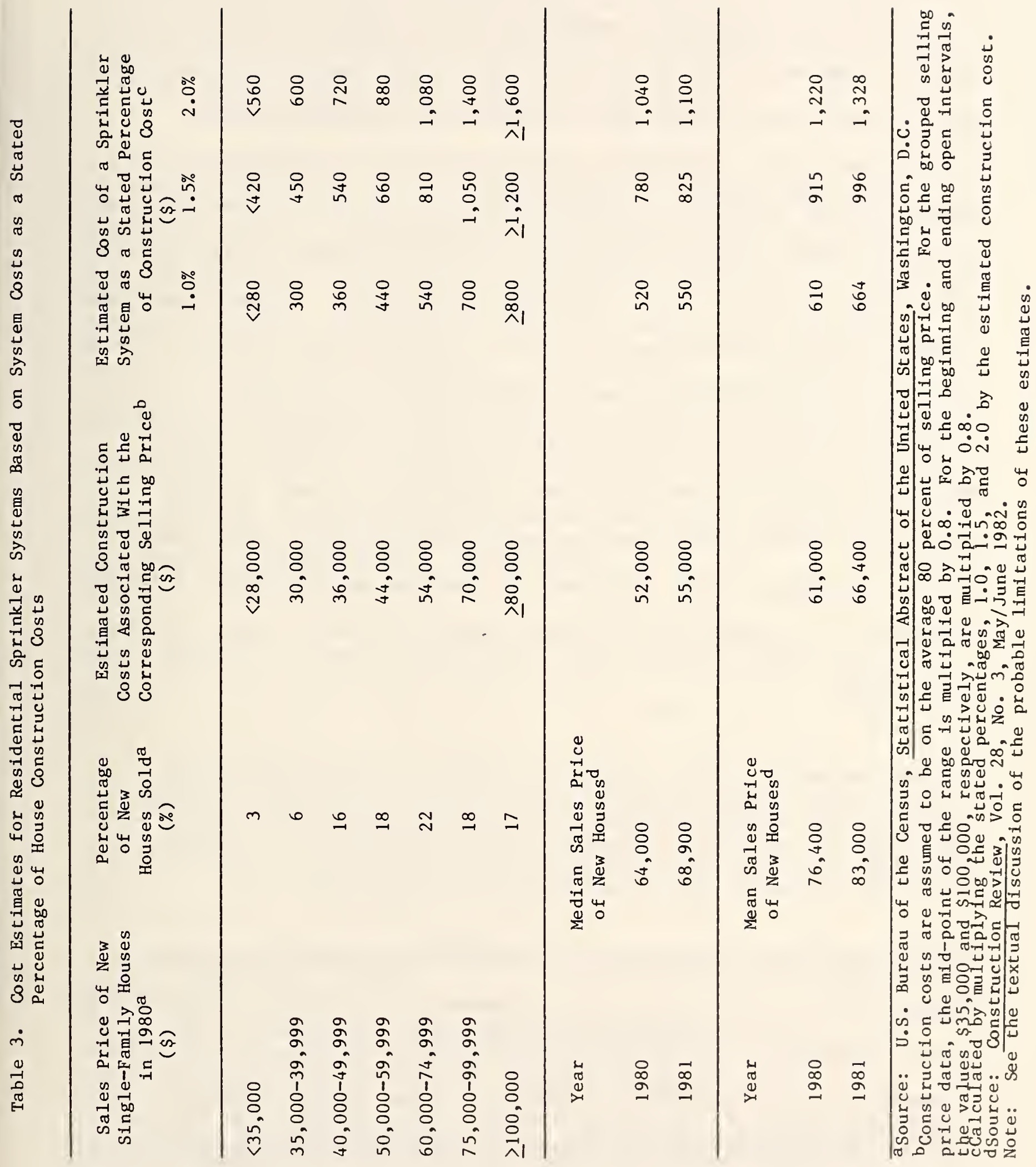


Inspection of these sprinkler system cost estimates, derived as specified percentages of house construction costs, reveals the obvious limitation of this estimation method: it fails to account for a fixed element of system costs and for variations in system costs not adequately predicted by house construction costs. For example, a house that sells for $\$ 35,000$ can have a number of rooms comparable to an $\$ 80,000$ house, although the rooms will 1ikely be smaller and/or less well constructed. A similar number of sprinkler heads may be required in both cases to meet code requirements. Although the linear footage of piping required may be less for the less expensive house, it is not likely to be proportionately less in relation to construction cost differences, other things being equal. In short, the cost of a sprinkler system will likely be lower, the lower the cost of the house, but the relationship between system cost and house cost is unlikely to be linear. Hence, estimating sprinkler costs as 1 to 2 percent of construction costs is likely to hold reasonably well only when applied to houses within a limited price range.

The cost estimate in table 3 closest in amount to that produced by the component cost estimate of table 2 for $1 / 2 "$ polybutylene piping is provided by taking 2.0 percent of a house sales price of $\$ 100,000$.

Cost estimates for sprinkler systems are also often quoted in terms of an average cost per square foot of total housing floor area or of protected floor area. For example, the cost of systems installed in compliance with the San Clemente, California, residential sprinkler system ordinance was reported in 1981 to average about $\$ 0.50$ per square foot, unspecified as to total area or 
protected area.1 A 1977 study estimated costs at $\$ 0.65$ per square foot of protected area for new houses in urban areas and $\$ 0.85$ per square foot of protected area for new houses in rural areas. ${ }^{2}$ This translates into $\$ 0.80$ and $\$ 1.04$, respectively, in 1982 dollars.

For commercial buildings, a typical industrial-type sprinkler system was estimated in 1979 to cost approximately $\$ 0.80$ per square foot of building space, ${ }^{3}$ which equals about $\$ 0.98$ per square foot in 1982 dollars. A study of alternative methods of achieving fire safety in health care facilities, a specialized application of sprinklers, estimated the cost of installing sprinklers in nonhazardous areas at $\$ 2.00$ per square foot of protected area in 1978 dollars. 4 This cost, which could be expected to be higher than that for either commercial or residential applications, translates into $\$ 2.80$ per square foot of protected area in 1982 dollars.

Table 4 shows the results of applying the above estimated sample costs per square foot of house area to the range of house sizes reported in 1980.

This estimation approach has limitations akin to the preceding approach, due to the assumption of a linear relationship between sprinkler system costs and house size. The cost per square foot estimates of $\$ 0.50$ and $\$ 0.80$ result in

1"San Clemente Protects New Residences With Automatic Sprinklers," Fire Chief Magazine, August 1981, p. 100.

2 Rolf Jensen and Associates, Fire Suppression Technology, p. 11.

3 Federal Emergency Management Agency, Report to Congress, p. 52.

${ }^{4}$ Robert E. Chapman, Phillip T. Chen and William G. Hall, Economic Aspects of Fire Safety in Health Care Facilities: Guidelines for Cost-Effective Retrofits, National Bureau of Standards Interagency Report 79-1902, November 1979. 


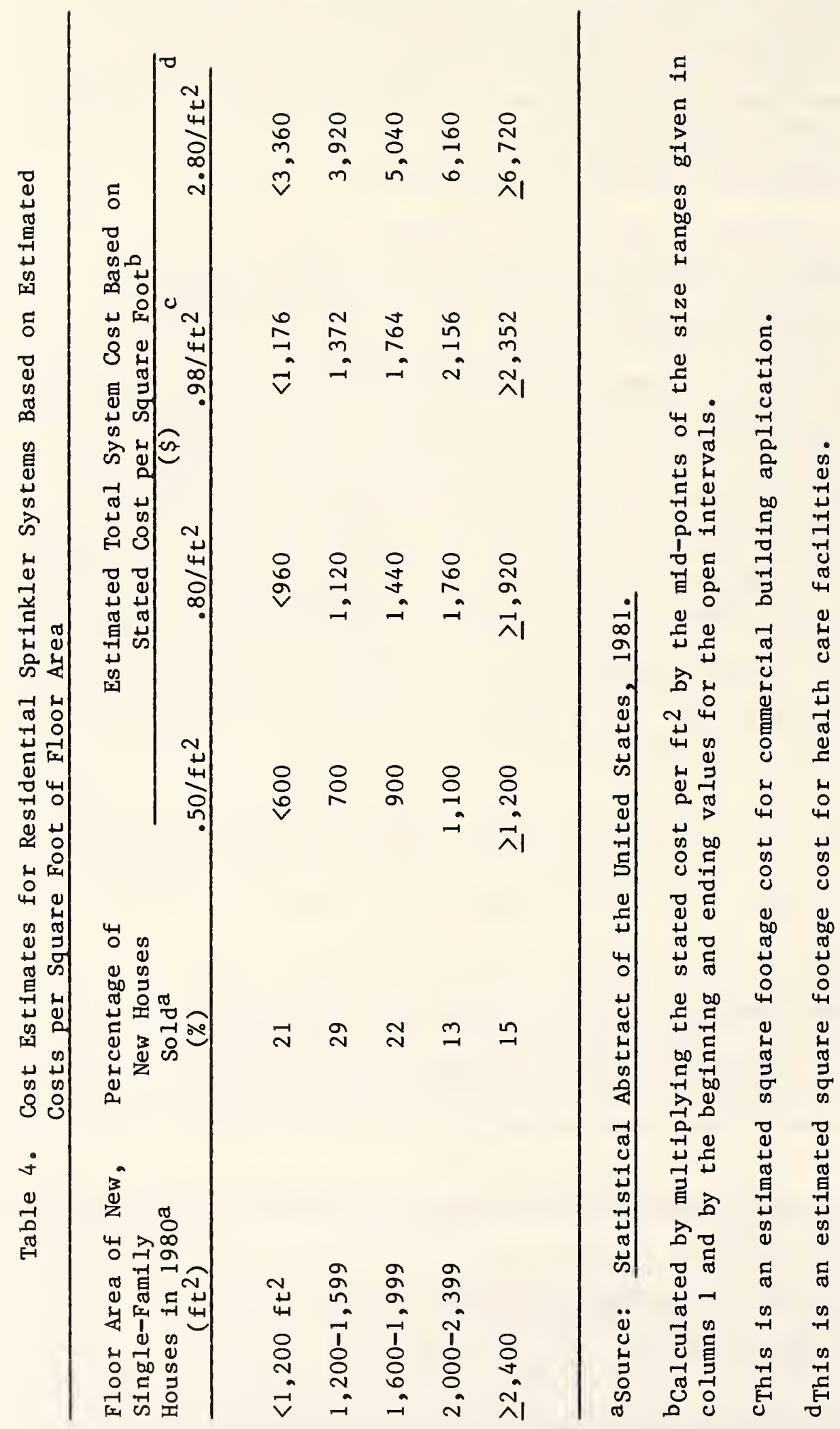


total cost estimates similar to those produced in table 3 by the 1.5 and 2.0 percentage figures. The total cost estimates resulting from the use of $\$ 0.98$ per square foot for houses in the 1,600-2,399 size range are closely in line with the estimates of $\$ 1,700$ to $\$ 2,000$ for a 2,000 square foot house suggested recently by fire protection consultants, and also bracket the component cost estimate for $1 / 2$ " polybutylene piping. The use of the health care cost per square foot produces total cost estimates substantially higher than any suggested by experts for residential systems.

A comparison of the component cost estimates of table 1 for a $11 / 4^{\prime \prime}$ copper pipe system with updated estimates of an earlier study (Rolf Jensen and Associates, Inc., 1977) based on $11 / 4^{\prime \prime}$ copper pipe, showed the component cost estimates to be somewhat higher: $\$ 1.89 / \mathrm{ft}^{2}$ of protected area versus $\$ 1.00 / \mathrm{ft}^{2}$ for the updated Jensen Study; and $\$ 1.77$ per sprinkler head versus $\$ 141$ for the updated Jensen Study.

To provide for sensitivity testing of the outcome to piping material and size, cases are included in section 3.3 based on $1 / 2$ inch polybutylene pipe and on 1 $1 / 4$ inch copper pipe, the former representing the low end of the pipe cost range and the latter the high end. The cost of a system using $1 / 2$ inch polybutylene pipe as estimated by the component cost method of table 2 is the cost estimate selected for performing the selected base-case example in section 3.3.1 (after adjustments for financing and tax effects). The estimated cost of a system using $11 / 4$ inch copper pipe is used in the sensitivity analysis of section 3.3 .2 . 


\subsubsection{Financing and Tax Effects}

The preceding cost estimates reflect neither the effects of financing nor related taxes. This section evaluates financing and tax effects and incorporates them into the analysis.

Financing. If a purchase is financed at the same rate as the purchaser's opportunity cost, i.e., the purchaser's borrowing rate equals the discount rate, financing a purchase has no effect on its present value acquisition cost before taxes. But if the borrowing rate is lower than the purchaser's discount rate, present value acquisition costs will be reduced by financing the purchase, and it will be economically advantageous for the purchaser to finance the purchase rather than to pay cash.

Based on a fixed-rate/uniform payment loan, the present value purchase and installation cost of a sprinkler system is calculated by amortizing the loan over the life of the loan at the specified borrowing rate, bringing the stream of loan payments back to present value at the specified discount rate, and adding the result to any downpayment amount. Although the sprinkler system costs will probably be included as part of the total house price and financed with the rest of the house, it is possible to treat it separately for the purpose of analysis.

Mortgage Interest Tax Deductions. For both an owner/occupant and an owner of a rental unit, the interest payments on a loan to finance the purchase of the system are deductible from taxable income, effectively reducing the acquisition cost of the system. With a fixed rate/uniform payment loan, the interest and principal components of each loan payment change over time. 
Because only the interest component is tax deductible, it must be separately estimated. This can be done period-by-period by calculating interest on the remaining principal balance, subtracting the interest from the payment amount--therein determining the contribution of that payment to reducing the principal--and then reapplying the interest rate to the new loan balance. The resulting cash flow is then multiplied by the marginal income tax rate, each value is discounted to present value, and the results summed to find the present value savings of interest expense deductions.

Combined Financing and Interest Tax Deductions. The present value of purchase and installation costs with financing and after interest deductions from taxable income can be calculated by equation 10 of section 2.2, omitting the last two terms for tax credit $(\overline{\mathrm{TC}})$ and depreciation ( $\overline{\mathrm{DTS}})$.

Using the component cost estimates for purchasing and installing polybutylene piping of $1 / 2$ inch diameter and assuming financing of the entire amount over 30 years at a market rate of interest of 15.5 percent compounded annually, an inflation-adjusted, after-tax discount rate of 11.30 percent, 1 and a marginal income tax rate of 40 percent, the present value of purchase and installation to either an owner/occupant or an owner of a rental unit is $\$ 1,445$, comprised of total present value payments of $\$ 2,292$ and an income tax savings of $\$ 847$, and calculated by equation 10 as follows:

$1_{\text {As }}$ was noted previously, purely inflationary effects must be removed from the analysis. Since the market rate of interest of 15.5 includes inflation, it is not appropriate to use the 6 percent real discount rate without adjusting it to include inflation. Applying the assumed inflation rate of 5 percent to the assumed after-tax real discount rate of 6 percent, yields 11.3 percent (i.e., .06 +.05+(.06) $(.05)=.113)$. 


$$
\begin{aligned}
P I & =\left[(\$ 1,718)(0)+[(\$ 1,718)(1-0)(0.157)(8.5)]-\sum_{j=1}^{30}\left[(0.4)\left(R P_{j}\right)(0.155)(S P W .113, j)\right]\right. \\
& =\$ 1,444.66
\end{aligned}
$$

This is the amount of purchase and installation cost used for the base-case analysis in section 3.3 .1 .1

Depreciation and Other Tax Effects. Several other tax effects may alter the effective ownership cost of a system to the owner of a rental house. The most important of these is depreciation of system acquisition costs, which reduces the after-tax costs of owning a system. Less important in most cases are capital gains tax and the depreciation recapture tax which are imposed upon sale. For residential real property, the gain from the resale of the property is taxed as ordinary income to the extent that accelerated cost recovery deductions exceed the depreciation that would have been allowed if the straight-line method had been used over a 15-year period. If the straight-1ine method is elected, all gain is taxed as capital gain. (Code Sec. 1250, Economic Recovery Tax Act of 1981.)

The impact of depreciation depends on the depreciation method and period, as well as the owner's tax rate. For new rental houses, a sprinkler system would usually be depreciated according to the same method and period used for the house. Residential property is currently depreciated according to either the accelerated cost recovery system or the straight-line method, usually over 15 years.

\footnotetext{
${ }^{1}$ The calculation was performed by use of a computer program.
} 
Based on the accelerated cost recovery system and a depreciation period of 15 years, the present value of income tax savings is modeled as follows:

$$
\overline{\operatorname{DTS}}_{A C R}=\sum_{j=1}^{15} U_{j} \cdot A_{j} A_{j} \cdot t \cdot S P W_{d, j}
$$

where,

$$
\begin{aligned}
\overline{\mathrm{DTS}}_{\mathrm{ACR}}= & \text { present value of income tax savings due to deductions from } \\
& \text { taxable income of depreciation expense based on the } \\
& \text { accelerated cost recovery system method, } \\
\mathrm{UDB}_{\mathrm{j}}= & \text { undepreciated balance of the depreciation cost basis remaining } \\
& \text { in year } \mathrm{j}, \text { normally equal initially to the full cost of system } \\
& \text { purchase and installation, and thereafter to the undepreciated } \\
& \text { balance at the beginning of the prior year less depreciation } \\
& \text { taken that year, } \\
\mathrm{ACRF}_{\mathrm{j}}= & \text { accelerated cost recovery factor which may be calculated as } \\
& \text { (100/15) (1.75), } \\
\mathrm{t}= & \text { homeowner's marginal income tax rate, and } \\
\mathrm{SPW}_{\mathrm{d}, \mathrm{j}=} & \text { single present worth discount factor. } \\
& {[\text { Note that depreciation is based on historical costs }} \\
& \text { and its nominal amount does not change in response to } \\
& \text { inflation or deflation; therefore, its value falls in terms } \\
& \text { of constant dollars if there is inflation. This can be taken } \\
& \text { into account by discounting the yearly nominal depreciation } \\
& \text { amount, UDB } j \text { ACRF } j \text {, with a discount rate which includes the } \\
& \text { inflation rate or by adjusting the yearly depreciation amount } \\
& \text { to constant dollars prior to the discounting operation.] }
\end{aligned}
$$

Based on the straight-line depreciation method, the present value of income tax savings is modeled as follows:

$$
\operatorname{DTS}_{S L}=\sum_{j=1}^{\mathrm{De}}(\mathrm{PI} / \mathrm{De}) \cdot t \cdot \mathrm{SPW}_{\mathrm{d}, j}
$$


where,

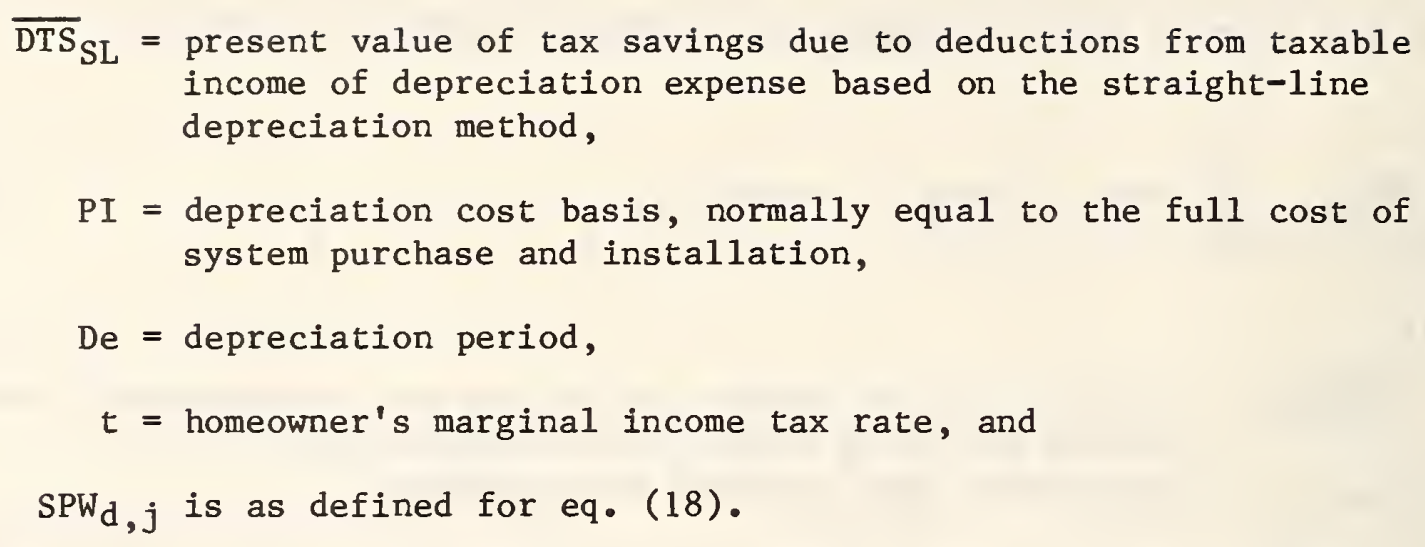

Using the straight-line method over 15 years, a marginal composite income tax rate of 40 percent, and an inflation-inclusive discount rate of 11.3 percent, the present value of the depreciation tax savings to the owner of a rental house is $\$ 358$; i.e.,

$$
\overline{\operatorname{DTS}}_{\mathrm{SL}}=\sum_{j=1}^{15} \frac{1718}{15}(0.4)\left(\mathrm{SPW}_{\mathbf{j}}, .113\right)=\$ 357.74
$$

This is the depreciation value used in the feasibility analysis for a rental house in section 3.3.2. Since the resale value of the system at the end of the thirty-year study period is assumed to be zero, there are no capital gains and no depreciation recapture tax to consider.

At the present there are no tax credits available to homeowners who purchase and install sprinkler systems. If available, tax credits provide a powerful stimulus to demand, because they reduce ownership cost by nearly a dollarfor-dollar of credit. The present value of cost reductions due to tax credits can be calculated as follows: 


$$
\overline{\mathrm{TC}}=\mathrm{tc} \cdot \mathrm{PI} \cdot\left(\mathrm{SPW_{1 } , \mathrm { d }}\right)
$$

where,

$$
\begin{aligned}
& \overline{\mathrm{TC}}=\text { present value of tax credit cost reductions, } \\
& \text { tc }=\text { percentage tax credit, } \\
& \mathrm{PI}=\text { purchase and installation cost of the system, and } \\
& \mathrm{SPW}_{1, \mathrm{~d}}=\text { single present worth factor for year } 1 \text {, assuming a one time }
\end{aligned}
$$

( $T$ ax credits are discussed further in section 3.2 .6$. )

\subsubsection{Other Potential Costs of Purchase and Installation}

Some localities have requirements, restrictions, and/or charges which raise the cost of purchasing and installing a residential sprinkler system. There may be, for example, special requirements for meters or backflow prevention valves, which are not technically necessary in most cases.1 Localities may also impose large monthly "water standby charges" or considerable permit fees in conjunction with a requirement that larger pipe size be used if sprinklers are installed. For instance, this study identified a policy of one public works commission of levying a $\$ 1,400$ permit fee for a 1 inch lead-in pipe and a $\$ 3,400$ permit fee for a $11 / 2$ inch lead-in, and of requiring a $11 / 2$ inch lead-in when a sprinkler system is used. This extra permit charge is in addition to the differential labor and materials cost of laying the larger pipe. Such a permit fee would add $\$ 2,000$ to the cost of a sprinkler system, raising the estimated total contract cost of a sprinkler system to between $\$ 3,718$ and $\$ 5,935$ (tables 1 and 2) depending on the choice of plastic or copper and the size of the pipe.

\footnotetext{
lFederal Emergency Management Agency, Report to Congress, p. 53.
} 
The rationality of this type of water demand charge is questionable because community water usage will likely be lowered, not raised, by sprinklers, since less water is required to control small fires than to fight large fires.l This type of charge, where it is imposed, constitutes a significant cost impediment to sprinkler use, and its validity and impact appear to warrant further exploration.

This potential cost is omitted from the base-case analysis, but is taken into account in the sensitivity analysis.

\subsubsection{Operating, Maintenance, Repair and Replacement Costs}

\subsubsection{Operating Costs}

The expected value of life-cycle operating costs to the owner/occupant $(\overline{\mathrm{OP}})$ is found as the present value sum of water costs $(\overline{\mathrm{WC}})$, water damage costs $(\overline{\mathrm{WD}})$, and, for systems with pumps, electricity costs $(\bar{E})$. Although the expected value of $\overline{\mathrm{OP}}$ is estimated to be a trivial amount that can be omitted from the analysis, each of the cost components is treated in turn below to demonstrate why the amount is estimated to be trivial.

Water costs would be incurred only if a system were activated. If the water line to the sprinkler system were metered, the homeowner or occupant would incur the cost; if the line were unmetered, the community would bear the cost. The fast-response time and the limit of activation to sprinklers in the immediate vicinity of a fire could be expected in most cases to limit the

I Ibid, p. 53. 
quantity of water released to a small fraction of the quantity of water that would be required if the local fire department combated the fire after an elapsed response time.

At a flow rate of 9 gallons per minute (the design flow rate of a recent test sprinkler system), an activated sprinkler head would release 270 gallons of water over a period of 30 minutes. This is about the same as a typical day's domestic water consumption for a household of four, and the marginal cost would generally be only a few cents. 1

The costs of water consumption and water damage can be evaluated as expected values, taking into account the probability of system activation in case of fire or accidentally.

The probability of fire occurring during a year in a one- or two-family dwelling is slightly less than 1 in 100 (it is 0.00856 based on 1981 data).2

The probability that a system is properly maintained and will operate effectively in response to a fire is estimated at 92 percent. ${ }^{3}$

IThe mean value for water consumption in the U.S. is 6,552 gallons per month for a household of 4 and the corresponding mean marginal price for water is $\$ .78 / 1,000 \mathrm{gal}$, as developed in S. F. Weber, B. E. Thompson and B. C. Lippiatt in Economic Framework for Cost-Effective Residential Water Conservation Decisions, NBSIR 81-2304, prepared by the National Bureau of Standards for the U.S, Department of Housing and Urban Development, Washington, D.C., August 1981 .

${ }^{2}$ Gomberg et al., A Decision Model for Evaluating Residential Fire-Risk Reduction Alternatives, NBSIR, in preparation 1984. See also section 3.2.1 for further explanation.

${ }^{3}$ Gomberg, et al., Evaluating Alternative Strategies For Reducing Residential Fire Loss, NBSIR 82-2551, August 1982, p. 15. 
Using the above estimated probability of a properly functioning system (.92), the probability of fire $(.00856)$, a water charge of $\$ .00078 / \mathrm{gal}$, the assumption that at most three sprinkler heads will be activated for no more than 30 minutes if a fire occurs--probably more heads activated and for a longer time than would generally occur--a real discount rate of 6 percent, a study period of 30 years, and level constant dollar prices (i.e., real price escalation rate $e=0$ ), one calculates the following life-cycle water consumption cost to the owner/occupant for activation induced by fire:

$$
\begin{aligned}
\overline{\mathrm{WC}}_{\mathrm{F}} & =(0.92)(.00856)(\$ .00078)(810 \mathrm{gal})(13.765) \\
& =\$ 0.068 .
\end{aligned}
$$

As expected, this cost is found to be trivial and can be omitted from the analysis.

The other water-related costs of a fire-induced sprinkler activation are the life-cycle costs of any water damage. It seems reasonable to assume that in absence of the sprinklers a much larger water damage would result from conventional fire fighting approaches. Because of the difficulty of estimating comparative costs, the differential value of water damage incurred by the homeowner is set equal to zero in the case studies, i.e. $\overline{\mathrm{WD}}_{\mathrm{F}}=0$.

Now consider water consumption costs and water damage costs associated with accidental activation, i.e. discharge of water when there is no fire. Although we do not know what the frequency of this type of failure for residential systems will be, we know that it is very rare in commercial and industrial applications.1 According to one study, "the leakage rate of

\footnotetext{
IFederal Emergency Management Agency, Report to Congress.
} 
sprinklers has been approximately one per year for each 3,000,000 sprinklers," and when leakage occurs it is generally limited to a single sprinkler head.1

The present value of the water consumption cost in case of fire-induced activation was shown to be trivial, and since the probability of accidental discharge for a residential application is low and uncertain, a specific calculation of this cost is not included in these examples.

The water damage costs from accidental discharge would be specific to the circumstances. For a library of rare books or a gallery of paintings, the water damage of actually incurred accidential discharge might be incalculable.

But under more typical conditions, the damage would likely be confined to a single room or portion of a conventially furnished room and the discharge, if prolonged, might entail costs of suctioning water from carpets, carpet cleaning and other floor refurbishing, possibly dry wall repair, repainting, and furniture cleaning and repair. A part of these costs might be covered by insurance.

Again, because there are no statistics on the frequency of accidental discharge for residential applications but there is reason to believe that it will be quite small, water damage costs are not included in the sample calculations. In the model of section 2.3 provisions are, however, made for calculating water consumption costs and water damage from accidental discharge.

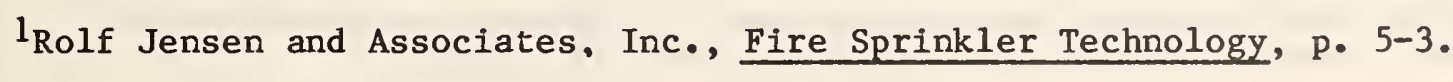


The other element of operating costs included in the initial listing is electricity cost, $\bar{E}$, for a system requiring a pump. Since these costs can be anticipated to be very small, and, in any case, apply only to a special application of sprinkler systems not treated here, they are assumed equal to zero in the cost analysis.

Hence, the expected value of life-cycle operating costs to the owner/occupant $(\overline{\mathrm{OP}})$ based on the above assumptions are estimated to be a trivial amount that can be omitted from the sample calculations.

\subsubsection{Maintenance, Repair, and Replacement Costs}

There is little experience upon which to base estimates of maintenance, repair, and replacement costs. In lieu of empirical data, the approach taken is to base the estimate on the assumption that an annual preventive maintenance and replacement program precludes the need for other repair costs. It is assumed that the annual preventive maintenance program consists of an inspection of one hour's duration performed by a sprinkler or plumbing contractor. The inspection is assumed to entail flow-tests of sprinkler heads, test of the alarm system; check of pumps and tanks if used; inspection of all valves; replacement of parts as needed; and a general check of all parts of the system.1

$1_{\text {NFPA } 13 D-1980}$ recommends a minimum monthly maintenance program. It does not specify who should perform the maintenance, but given the frequency of recommended inspection, if done, it is likely to be done by the owner. Hence, an alternative approach to estimating the cost of maintenance would be to estimate the opportunity cost of the owner's time. Costs were instead based on an annual inspection by a plumber or sprinkler contractor for two reasons: (1) a representative of a major sprinkler company advised that an annual inspection be performed by a professional in the field; and (2) wage rates of plumbing and sprinkler contractors are more definitive and generalizable than homeowner opportunity cost. (Telephone interview with Kathy Vernot, Central Sprinkler Corporation, Nov. 19, 1982.) 
The most frequent type of parts replacement is assumed to be of sprinkler heads, because they can be damaged by painting, dust, and water corrosion over time. NFPA 13D-1980 states that "at least 3 spare sprinklers of each type, temperature rating, and orifice size used in the system should be kept on the premises." However, there is no empirical data as to the actual frequency of the replacement. The approach chosen to estimate this component of cost is to assume that about half the sprinkler heads need to be replaced during a 30 year period, with the frequency of replacement lower during the earlier years and higher in the later years. Figure 3 shows the specific replacement pattern of sprinkler heads assumed for this calculation. It it assumed that the replacements are performed as a part of the preventive maintenance program; costs for parts but not for additional labor are estimated. Other components of the system are assumed to last 30 years without replacement.

Equation (15) of section 2.2 is used to estimate the present value of maintenance, repair and replacement costs, i.e.

$$
\begin{aligned}
& \bar{M}=\left[\left(w_{m} \cdot h_{m} \cdot U P W^{*} d, n, e\right)+\sum_{j=1}^{h}\left[\left(w_{r r j} \cdot h_{r r j}\right)+m_{r r j}\right] \cdot S P W^{*} d, j, e\right] \\
& {[1-(t \cdot A)] .}
\end{aligned}
$$

The portion of equation (15) that pertains to maintenance costs can be separately identified as follows:

$$
\overline{\mathrm{ME}}=\left(w_{\mathrm{m}} \cdot \mathrm{h}_{\mathrm{m}} \cdot \mathrm{UPW}^{*} \mathrm{~d}, \mathrm{n}, \mathrm{e}\right) \cdot[1-(t \cdot \mathrm{A})],
$$




\section{Figure 3. Assumed Annual Rate of Replacement of Sprinkler Heads During System Lifea}

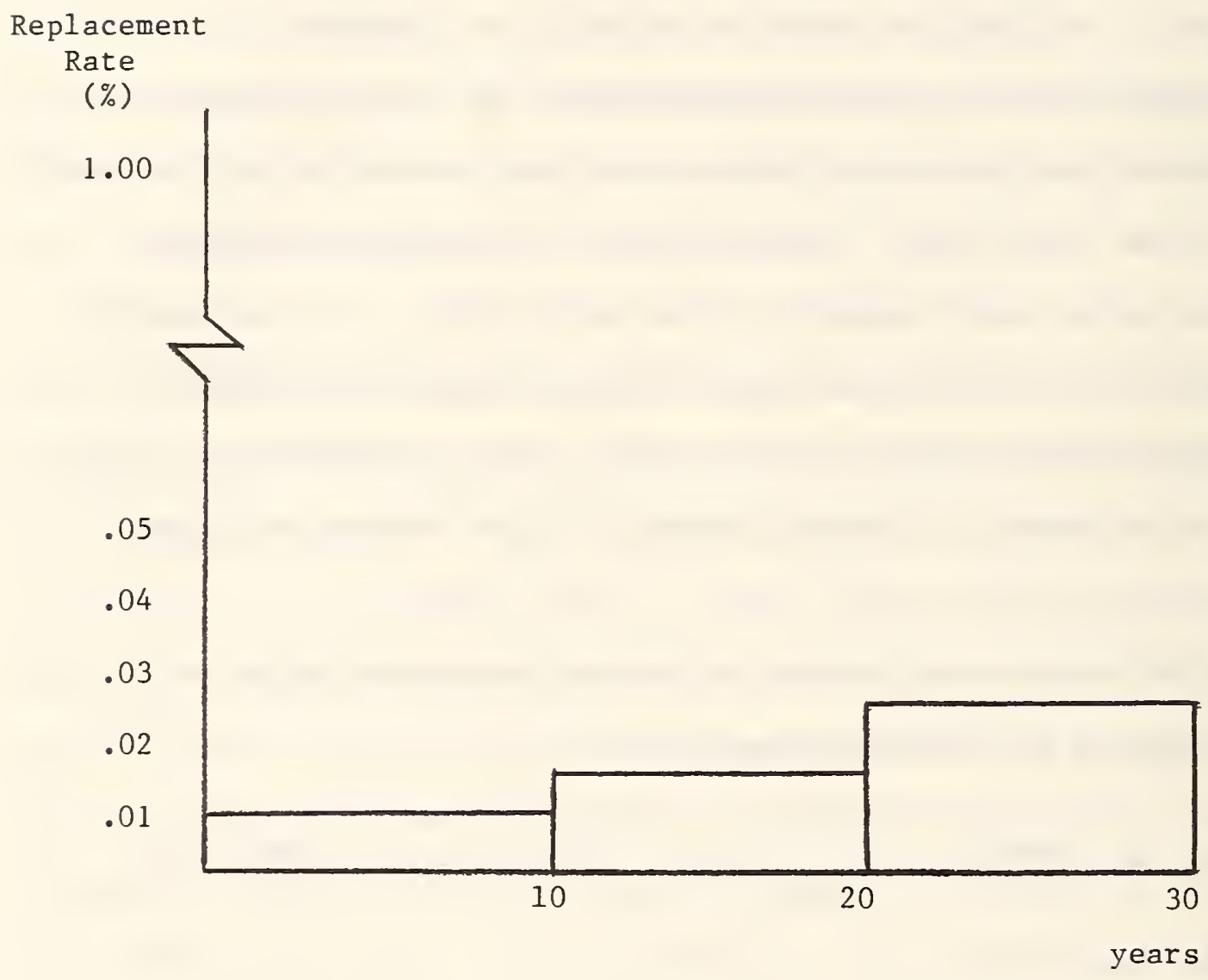

aThis replacement schedule allows for replacement of one-half of the 21 heads over the life of the system: an average of 2.1 during the first 10 years, 3.15 during the next 10 years, and 5.25 during the last 10 years. 
where,

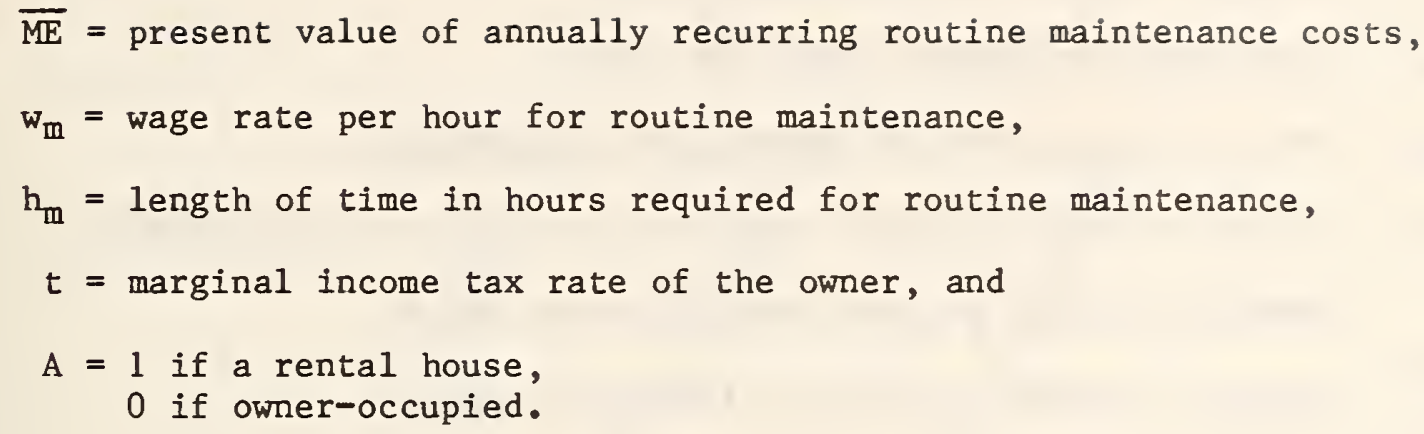

Based on a constant dollar hourly wage rate of $\$ 27.65^{1}$, and one hour for the annual inspection, the present value cost to the owner-occupant over 30 years is $\$ 380$; i.e.,

$$
\overline{\mathrm{ME}}=(\$ 27.65)(1)(13.76)=\$ 380.46
$$

To the owner of a rental unit in a 40 percent tax bracket, the present value cost is $\$ 228 ;$ i.e.,

$$
\overline{\mathrm{ME}}=\$ 380.46(1-.4)=\$ 228.28
$$

The portion of equation (15) that pertains to replacement and repair costs can be separately identified as follows:

$$
\bar{R}=\sum_{j=1}^{n}\left[\left(w_{r r j} \cdot h_{r r j}\right)+m_{r r j}\right] \cdot s P w^{\star} \underset{d, j, e}{ } \cdot[1-(t \cdot A)]
$$

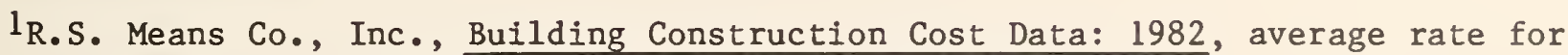
plumbers in U.S. cities, including overhead and profit. 
where,

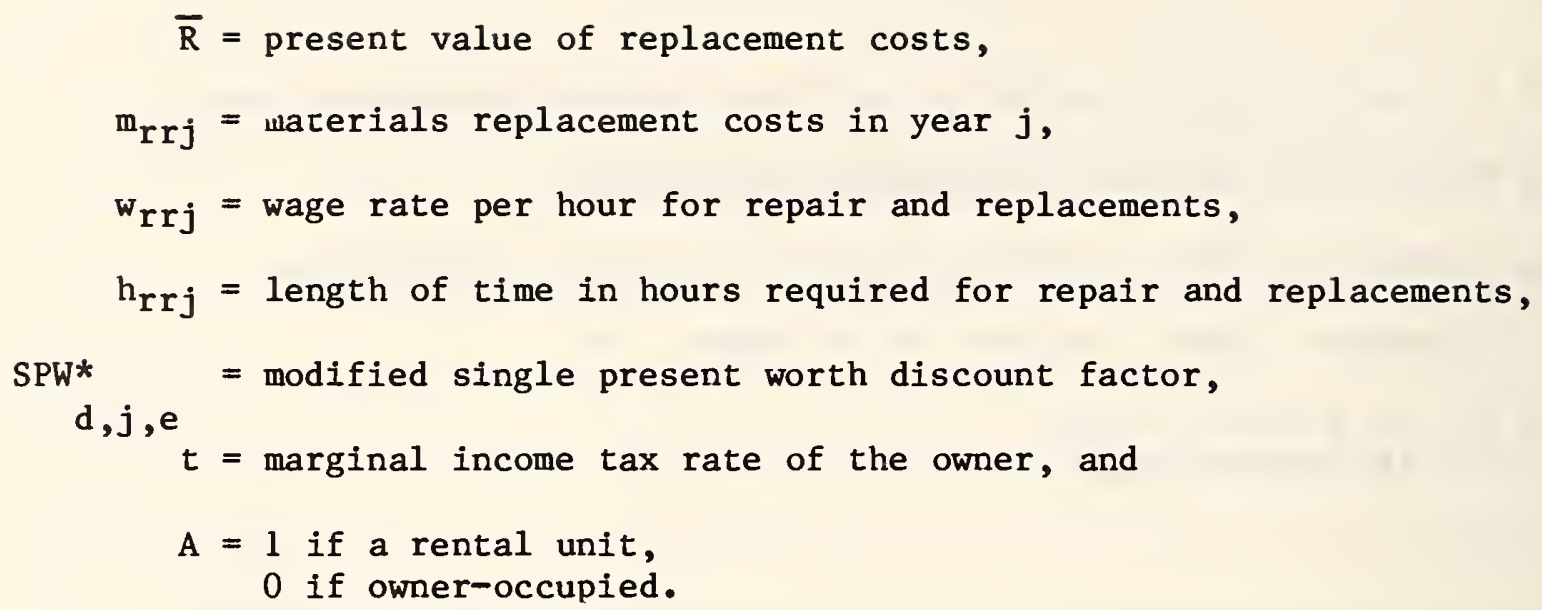

Since it is assumed that the labor cost for replacements is included in the preceding calculation of $\bar{M}$ and that maintenance prevents unscheduled repairs, $\left(w_{r r j} \cdot h_{r r j}\right.$ ) is given a zero value and $m_{r r j}$ is given the materials replacement cost of $\$ 10$ per head.

If costs recur over intervals of time shorter in length than $n, U^{*} W^{*}, d, e$ factors for each time interval can be used in conjunction with $S P^{*}{ }_{j}, d, e$ factors for the beginning of each time interval to calculate present value costs. For example based on a constant dollar replacement cost per sprinkler head of $\$ 10.00,21$ sprinkler heads of which half are replaced during the system life, and the replacement schedule given by figure 3 , the present value cost to the owner/occupant over 30 years is $\$ 40$; i.e., 


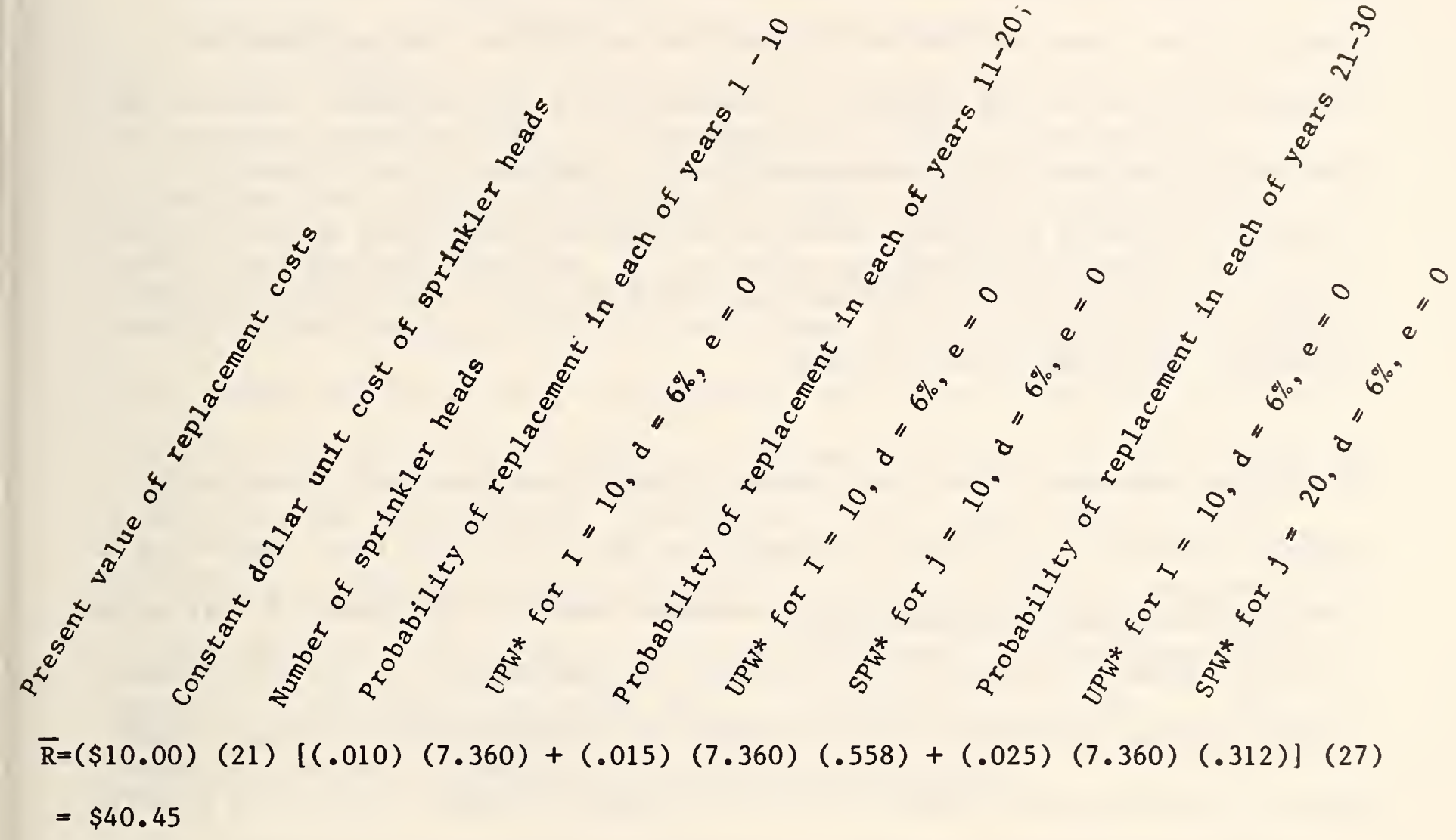

For the owner of a rental unit in a 40 percent tax bracket, the present value of replacement is $\$ 24 ; 1 . e$. ,

$$
R=(40.45)(1-.4)=\$ 24.27
$$




\subsubsection{Increased Property Taxes}

Because automatic sprinkler systems are capital intensive, they will tend to increase the value of a house, and, hence, raise its property tax assessment basis, unless a specific waiver or exemption is granted. The purchase and installation cost of the system is a reasonable, though imprecise, indicator of the initial increase in the assessment basis. Thereafter, the differential value in the yearly assessment basis may be modeled taking into account the net effect of deterioration or obsolescence, which may lessen the value, and price increases, which may raise the value.

Percentage assessment levels and nominal property tax rates vary dramatically among localities, but effective property tax rates vary much less. According to the U.S. Statistical Abstract 1980, assessment levels in 30 large U.S. cities in 1978, for example, ranged from 98.1 percent in Washington, D.C. to 10.0 percent in New Orleans, and nominal rates per $\$ 100$ for the same group of cities ranged from 1.25 percent in Los Angeles to 25.29 percent in Boston. Effective property tax rates ranged from 0.82 percent in Honolulu to 7.46 percent in Boston, and averaged 2.15 percent across the 30 cities.

Assuming a straight-line obsolescence rate, the present value increase in property tax may be calculated by equation (16). Basing the purchase and installation cost on $1 / 2$ inch polybutylene pipe for a single-family residence, using an effective tax rate of 2.15 percent (constant over the 30 years), and, assuming no real price changes over a 30-year study period and a 6 percent discount rate, the present value of property tax is $\$ 190$; i.e., 


$$
\begin{aligned}
\bar{P} & =\sum_{j=1}^{30}(\$ 1,718)(1-j / 30)(.0215)\left(S P W^{*}, d=6 \%, e=0\right)(1-0.4) \\
& =\$ 189.72 .
\end{aligned}
$$

\section{1 .4 Cost Summary}

The previous three sections, 3.1.1 through 3.1.3, have established and illustrated cost estimating procedures for three main cost categories for residential sprinkler systems: (1) purchase and installation costs, (2) operating, maintenance, repair, and replacement costs, and (3) property taxes. The purchase and installation costs were given in terms of ranges due to the variability in these costs depending, for example, on type and size of pipe, and system size and configuration. Because there is no "track record" of the reliability, durability, and maintainability of these systems, it was necessary to base operating, maintenance, repair and replacement cost estimates on a number of assumptions about which there is considerable uncertainty. Table 5 summarizes the costs selected for the base-case analysis.

\subsection{Benefits}

This section focuses on the value of benefits to the homeowner of acquiring a sprinkler system. These benefits are primarily the value of reduced risk of death, injury, property loss, and related indirect costs; lower insurance costs; and, depending on community actions, lower property taxes and reduced housing costs. 
Table 5. Summary of "Base Case" Costs for Residential Sprinkler Systems

\begin{tabular}{|c|c|c|}
\hline \multirow[b]{2}{*}{ Type of Cost } & \multicolumn{2}{|c|}{ Homeowner Costs } \\
\hline & $\begin{array}{c}\text { Owner/Occupant } \\
(1982 \$) \\
\end{array}$ & $\begin{array}{c}\text { Owner of a } \\
\text { Rental House } \\
(1982 \$)\end{array}$ \\
\hline $\begin{array}{l}\text { Purchase and Installation Cos } \\
\text { after taxes and financing }\end{array}$ & & \\
\hline $\begin{array}{l}\text { ( } 1 / 2 " \text { Polybutylene Pipe -- } \\
\text { Component Method Estimate) }\end{array}$ & 1,445 & 1,445 \\
\hline Depreciation Tax Savings & & $(358)$ \\
\hline $\begin{array}{l}\text { Operating, Maintenance, } \\
\text { Replacement and Repair Costs }\end{array}$ & & \\
\hline Operating Costs & 0 & 0 \\
\hline Maintenance Costs & 380 & 228 \\
\hline Replacement Costs & 40 & 24 \\
\hline Property Taxes & 190 & 190 \\
\hline Total & 2,055 & 1,529 \\
\hline
\end{tabular}




\subsubsection{Reduced Risk of Death and Injury}

The assignment of a dollar value to deaths and injuries averted is frequently done--either implicitly or explicitly--but not without controversy and inconsistency. Stating all costs and benefits in dollars is desirable because it facilitates comparisons using a variety of economic measures of performance. Placing a dollar value on human life, pain, and suffering, however, raises difficult philosophical, ethical, and theoretical issues. For example, basing the value of a life on the present value of earnings potential --one of the measurement approaches that is sometimes used--tends to result in comparatively low values for the young and the old and, in our present economy, for women and non-Caucasians. Using court-assigned values for death, pain, and injury inflicted--another approach that is sometimes used--results in widely variable amounts. The values of saving lives and reducing pain and injury implicitly assigned by other government programs concerned with safety also vary widely among programs and projects. 1

The approach considered most consistent with economic theory is based on the willingness-to-pay concept. The willingness-to-pay value is computed according to how much a decision maker will invest to reduce his risk of death by a certain fraction. In a parallel fashion the concept can be applied to the risk of suffering injuries. While the approach and the methods are still under debate, it is interesting to note that surveys of expressed willingness to pay for small reductions in the risk of death have yielded

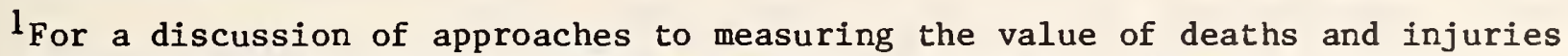
averted, and deficiencies of these approaches, see E.J. Mishan, "Evaluation of Life and Limb: A Theoretical Approach," Journal of Political Economy, JulyAugust 1971, pp. 687-705; or M.W. Jones-Lee, The Value of Life: An Economic Analysis, Chicago, IL: University of Chicago Press, 1976. 
values of life from $\$ 50$ thousand to $\$ 8$ million, with most values concentrated between $\$ 250$ thousand and $\$ 1$ million. 1

Rather than attempting to develop new measures of the value of averting death, pain and suffering, this study uses the following two approaches:

(1) In the first approach, values within the range of $\$ 250$ thousand to $\$ 1$ million are adopted from the NBS/SRI Fire Loss Mode1 to convert the reduction in lives lost and injuries to economic terms. The assumed dollar value per life saved in the base-case example is $\$ 500,000$. The assumed value per injury averted is $\$ 20,000$.

The cash flows resulting from these estimates are discounted to present value to put them on a common time basis with the costs, and the present value of net benefits is calculated.

(2) In the second approach, total benefits, not including the benefits of reduced risk of death and injury, are subtracted from total costs to derive a partial net dollar cost. The estimated number of injuries averted is divided by the estimated number of deaths averted to obtain the number of injuries averted for each life saved. The net dollar cost is then divided by the expected total number of deaths averted over the study period to obtain a present value cost per life saved and so many injuries averted. 2 This quotient represents the minimum value that a decision maker could ascribe to a sprinkler system's benefit of reduced risk of death and injury and find the system cost effective. Hence, the method solves for a value of life and TJ. D. Graham and J. W. Vaupe1, "Value of a Life: What Difference Does It Make?", Risk Analysis, Vol. 1, No. 1, March 1981, p. 89.

2 This approach is discussed by John S. McConnaughey, Jr. in An Economic Analysis of Building Code Impacts: A Suggested Approach, NBSIR 78-1528, October 1978, pp. 30-31. 
injury against which the decision maker must compare his or her own value. If, using this approach, the number of deaths averted are simply summed over the study period, the value of all deaths and injuries, present and future, will be weighted equally.1 In contrast, discounting the estimated dollar value of deaths and injuries averted means that future deaths and injuries are valued less than those current.

A further difficulty in evaluating the benefits of reduced risk of death and injury, as well as of property loss, is that the risk reduction depends on sprinkler system performance. This study uses the rates of deaths, injuries, and property loss reductions developed by the NBS/SRI Fire Loss Model, based on expert judgment and extrapolations applied to the results of laboratory and field tests. 2

Two conditions of sprinkler performance are considered: (1) the sprinkler is to be used without a functional smoke detector in the residence (i.e., the detector is either nonfunctional or not present), and (2) the sprinkler system is to be used in combination with a functional smoke detector. The second condition is much more realistic in that it is highly unlikely that a home protection system would ever include sprinklers and not detectors. The first condition of sprinklers used alone is included, however, to suggest the added benefits that may accrue to a sprinkler system in the circumstance where the benefits of smoke detectors may not be attainable.

For a discussion of discounting the value of lives saved, a controversial issue, see Richard Zeckhauser, "Procedures for Valuing Lives," Public Policy, Vo1. No. 4, Fall 1975, pp. 419-464.

2A. Gomberg, et al., A Decision Model for Evaluating Residential Fire-Risk Reduction Alternatives, NBSIR, in preparation 1984. 
The impact of the sprinkler system on risk of death, injury, and other losses will differ depending on which of these two conditions exists. The first condition -the sprinkler system used alone -results in the greatest loss reduction attributable to sprinklers. However, since smoke detectors are very inexpensive, provide early fire warning, are now required by many localities, and in fact, are included as a component of the fire sprinkler kit currently marketed, the second condition appears much more reasonable, as was noted above. With the second case, it is necessary to separate the loss reduction effects of the sprinkler from those of the detector. The results will depend on whether the sprinkler is treated as an addition to the detector or vice versa. In this analysis, the sprinkler is assumed to be an addition to the detector because of the detector's lower cost and earlier adoption in the marketplace.

Impact data based on the results of laboratory and field tests, shown in table 6, are used to estimate the effectiveness of sprinklers in reducing the risk of death and injury from fires under the stated conditions. The estimates reflect the assumption of a malfunction rate of 8 percent, corresponding to the assumption made in section 3.1 .2 for estimating operation, maintenance, repair, and replacement costs.

From the predicted impact data, estimated percentage reductions in fire deaths and injuries attributable to residential sprinkler systems can be derived. These percentage reductions are shown in table 7 .

The probability of fire occurring in a one- or two-family house within a given year, $P(F)$, is found as the number of reported fires in one- and two-family 


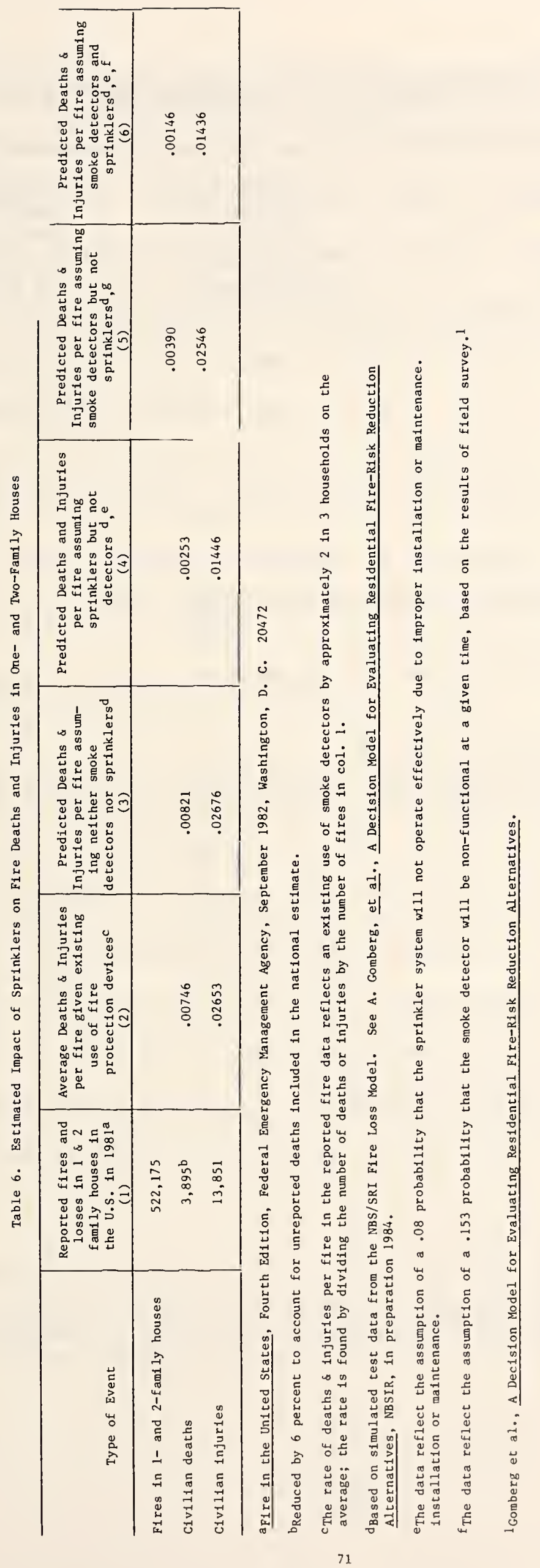


Table 7. Estimated Percentage Reductions in Fire Deaths and Injuries Attributable to Residential Sprinkler Systemsa

$$
\begin{aligned}
& \text { Condition } 1 \\
& \text { Sprinkler } \\
& \text { But No } \\
& \text { Detector } \\
& \text { (\% Decrease) }
\end{aligned}
$$

Condition 2 Detector Present When Sprinkler is Added

(\% Decrease)

Deaths

69

63

Civilian Injuries

46

44

aperived as follows from the estimated impact data of table 6:

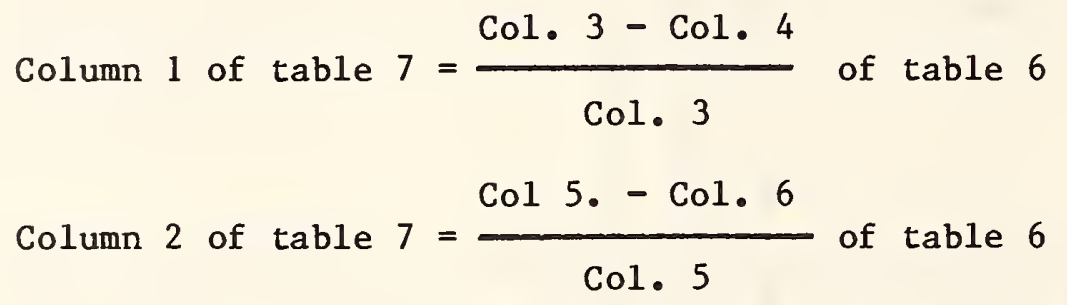


houses during that year, expressed as a percentage of the total number of oneand two-family houses in the housing stock at that time, i.e., $P(F)=$ $N(F) / N(H)$, where $N(F)=$ number of fires and $N(H)=$ number of houses in the housing stock. Using the number of reported fires in one- and two-family houses during 1981, and the size of the stock of one- and two-family houses in 1981 , the probability of fire occuring during the year is .00856; i.e., $522,175 \div 61,000,000=.00856 .1$

The conditional probability of death given that a fire occurs, $P(D \mid F)$, is equal to the joint frequency of fire and death divided by the marginal frequency of fires, i.e., $\frac{N(F \& D)}{N(F)}$. The joint probability of a fire occurring and death resulting, $P(F \& D)$, is $P(F) P(D \mid F)$.

$P(F \& D)$ can be subscripted "pc" to denote the risk "condition" just prior to the introduction of the sprinkler, and "s" to denote the risk condition after sprinkler installation. Applying the estimated percentage reduction in $P(D \mid F)$ attributable to the sprinkler, abbreviated $p(s, f)$, to the joint probability of death and fire under the prior protection state, $P(F \& D)_{p c}$, results in the estimated reduction in risk of death attributed to the sprinkler system. Multiplying the change in risk by the estimated average value of a life lost, and the resulting product by the uniform present worth factor to discount the

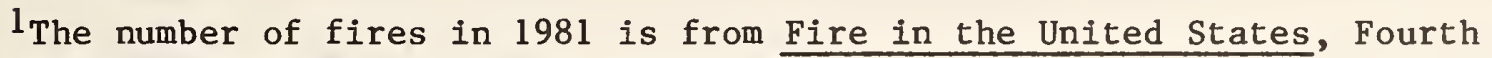
Edition; the number of one- and two-family houses in the housing stock is based on the latest available Census data. 
30-year stream of annual savings to present value, yields an estimate of present value benefits of reduced risk of death. The benefit of reduced risk of injury can be similarly calculated.

The combined present value benefits of reduced risk of death and injury to the homeowner can be calculated by equation (5). No difference in benefits is estimated for the owner/occupant and the owner of a rental unit, although the situations differ. It is assumed that the owner/occupant will receive the benefits of reduced personal risk directly, while the owner of the rental unit will receive the benefits through a rent premium that reflects the tenants' receipt of the reduced risk benefits.

Values per death (DV) of $\$ 500,000$ and per injury (IV) of $\$ 20,000$ are used. The values are assumed to remain level in constant dollars over a 30 year period. Appropriate values for $P(F \& D)_{p c}$ and for $P(F \& I)_{p c}$ are taken from table 6. Appropriate values for $p(s, f)$ and for $i(s, f)$ are taken from table 7 . The present value benefit to the homeowner (owner/occupant or owner of a rental unit) is estimated to be $\$ 362$ in the absence of smoke detectors, and $\$ 171$ when sprinklers are added to smoke detectors, i.e., Condition 1: No Detector/Sprinkler System $\overline{\mathrm{DI}}=[(0.69)(0.00856)(0.00821)(\$ 500,000)+(0.46)(0.00856)(0.02676)(\$ 20,000)]$

$$
(13.765)=\$ 362.85
$$

Condition 2: Detector/Sprinkler System

$$
\begin{aligned}
\overline{\mathrm{DI}}= & {[(0.63)(0.00856)(0.00390)(\$ 500,000)+(0.44)(0.00856)(0.02546)(\$ 20,000)] } \\
& (13.765)=\$ 171.23 .
\end{aligned}
$$

(Note that the specific number of occupants of the house at the time of a fire is not specified, but is implicitly assumed to be equal to the average 
occupany rate of houses in which there were reported fires and deaths and injuries in 1981, the year for which the data were reported. Also note that for the entire community, benefits include an additional element, firefighters' deaths and injuries averted by sprinkler systems, which are not included in the homeowner's risk assessment.)

\subsubsection{Reduced Risk of Direct Loss}

The benefits from reduced risk of direct loss, that is, property loss, are presented separately from the benefits associated with deaths and injuries because there is less uncertainty in ascribing dollar values to property losses than to death and injury. The evaluation procedure is, however, similar to the foregoing, with the following difference: Unlike deaths and injuries, property losses are reported empirically in dollars, and the predicted impact of sprinklers on property losses is stated in terms of change in dollar loss per fire rather than change in the frequency of loss occurrence.

To calculate benefits of reduced direct loss, the predicted percentage reduction in direct loss per fire is multiplied by the average direct dollar loss per fire for the condition existing just prior to sprinkler installation, and the result is multiplied by the marginal probability of fire and by the discount factor to convert the yearly savings to a present value over 30 years, as provided for by equation (6). The estimated average dollar value of direct dollar loss per fire under alternative conditions of fire protection are shown in table 8 , as are the derived percentage decreases in direct losses attributed to sprinklers. 
Table 8. Estimated Impact of Sprinklers on Direct Fire Loss in One- and Two-Family Houses

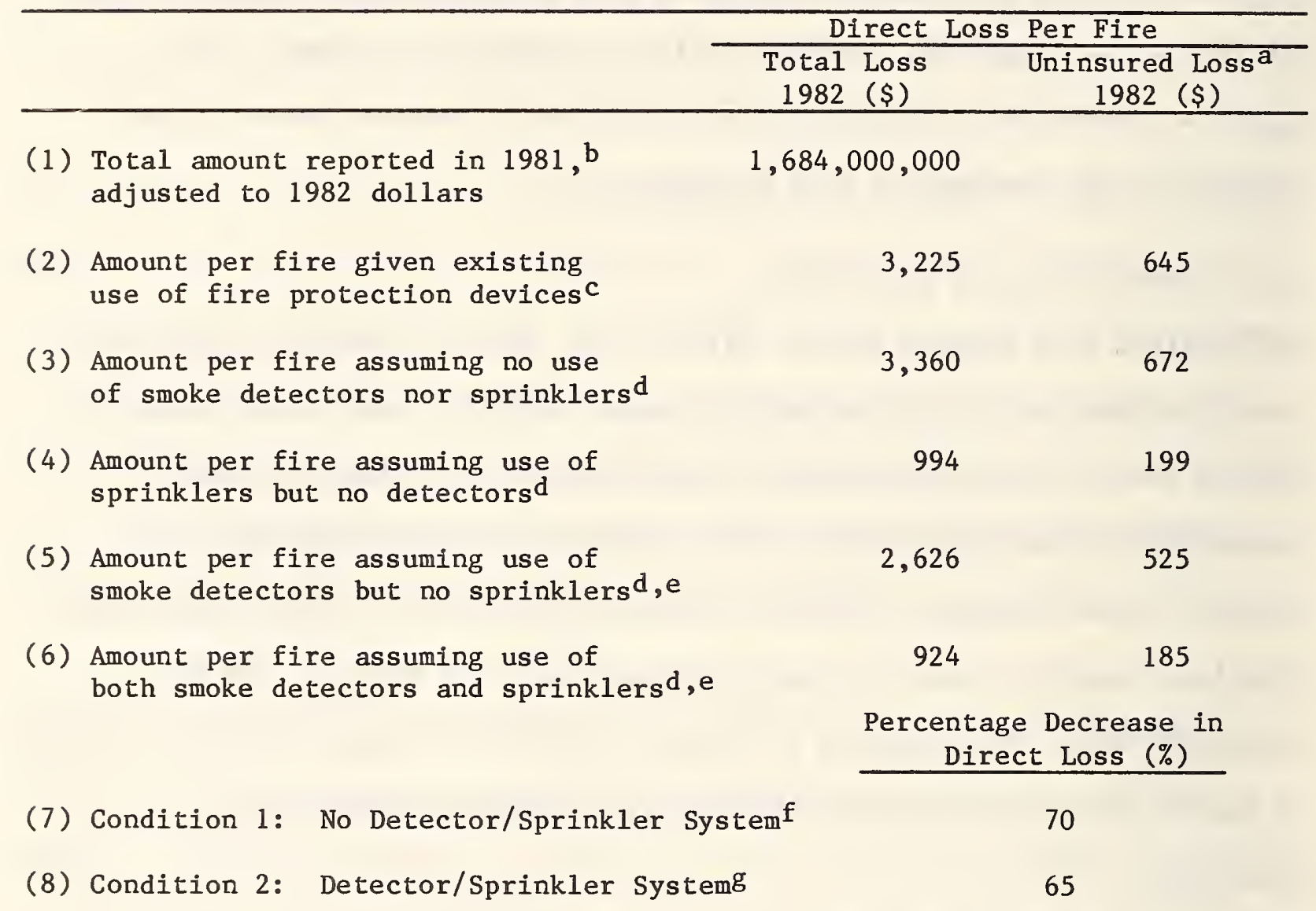

ansurance of property by the homeowner is assumed to cover 80 percent of any property loss.

bFire in the United States, Fourth Edition, Federal Emergency Management Agency, September 1982, Washington, D. C. The 1981 estimate was adjusted to 1982 dollars by applying the Consumer Price Indices for October 1981 of 279.9 and for October 1982 of 294.1.

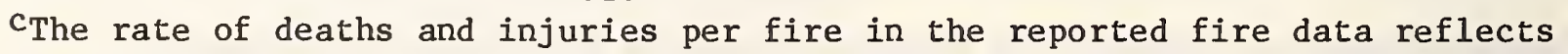
an existing use of smoke detectors by approximately 2 in 3 households on the average.

dBased on simulated test data from the NBS/SRI Fire Loss Model in Alan Gomberg et al., A Decision Model for Evaluating Residential Fire-Risk Reduction Alternatives, NBSIR, in preparation 1984.

e The data reflect the assumption of a 16 percent probability that the smoke detector will be nonfunctional at a given time, based on the results of field survey.

$\mathrm{f}_{\text {Row }} 7$ is derived as $\frac{\text { Row } 3-\text { Row } 4}{\text { Row } 3}$

gRow 8 is derived as $\frac{\text { Row } 5-\text { Row } 6 .}{\text { Row } 5}$ 
The value of reducing the risk of direct losses is assumed to be equal for the owner/occupant and the owner of a rental house, although its components differ. The owner of a rental house is assumed to benefit directly from reductions in uninsured losses to the structure, and to benefit indirectly through rent premiums from reductions in uninsured and non-reimbursable losses to tenants. Insurance is assumed to cover 80 percent of any property loss. Using the estimates of table 8, the present value benefits to the homeowner (owner/occupant or owner of a rental unit) of uninsured property losses are estimated to be $\$ 55$ under Condition 1 and $\$ 40$ under Condition 2; i.e.,

\section{Condition 1: No Detector/Sprinkler System}

$\overline{\mathrm{PL}}=(.70)(.00856)(672)(13.765)=\$ 55.43$

Condition 2: Detector/Sprinkler System

$\overline{\mathrm{PL}}=(.65)(.00856)(525)(13.765)=\$ 40.21$

The present value benefits of reducing total property losses (insured and uninsured) are estimated to be $\$ 277$ under Condition 1 and $\$ 201$ under Condition 2; i.e.,

Condition 1: No Detector/Sprinkler System

$\overline{\mathrm{PL}}=(.70)(.00856)(3360) 13.765)=\$ 277.13$

Condition 2: Detector/Sprinkler System

$\overline{\mathrm{PL}}=(.65)(.00856)(2626)(13.765)=\$ 201.12$ 


\subsubsection{Reduced Risk of Indirect Costs}

The indirect cost data in table 9 are stated as average amounts per fire. Table 10 gives the derived estimates of indirect costs under various conditions of sprinkler and smoke detector use. Indirect costs are assumed to change under the various conditions proportionately to the change in direct costs. 1

As in the cases for death, injury, and property losses, no difference in benefits is estimated for the owner/occupant and the owner of a rental unit. This is because it is assumed that the owner of a rental unit will receive benefits equivalent in amount to those of the owner/occupant through a rent premium that reflects the tenant's benefit of reduced risk of indirect costs. Like property losses, indirect costs are assumed to be partially insured; therefore, there is a divergence between homeowner costs and social costs.

Using the estimates of tables 9 and 10, together with previously established parametric values, the present value benefits to the homeowner (owner/occupant or owner of a rental unit) of reducing out-of-pocket indirect costs are estimated by equation (7) to be $\$ 18$ under Condition 1 , and $\$ 13$ under Condition 2 ; i.e.,

Condition 1: No Detector/Sprinkler System $\bar{C}=(.70)(.00856)(\$ 218)(13.765)=\$ 17.98$

Condition 2: Detector/Sprinkler System $\bar{C}=(.65)(.00856)(\$ 171)(13.765)=\$ 13.10$

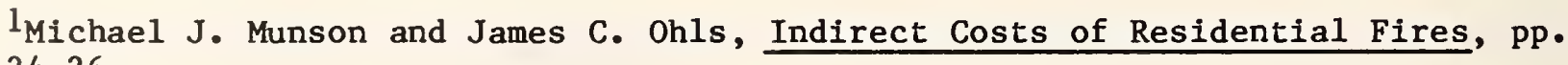
24-26. 
Table 9. Estimated Indirect Costs of Residential Firesa

\begin{tabular}{|c|c|c|c|}
\hline $\begin{array}{l}\text { Type of } \\
\text { Indirect } \\
\text { Fire Costs }\end{array}$ & $\begin{array}{l}\text { Percentage of } \\
\text { ires Involving } \\
\text { the Various } \\
\text { Types of } \\
\text { Indirect Costs } \\
(\%)\end{array}$ & $\begin{array}{c}\text { Average Total Indirect } \\
\text { Cost per Residential } \\
\text { Fire Given Existing Use } \\
\text { of Fire Protection } \\
\text { Devicesc } \\
(1982 \$)\end{array}$ & $\begin{array}{l}\text { Average "Out-of- } \\
\text { Pocket" Cost per } \\
\text { Fire Given Exist- } \\
\text { ing Use of Fire } \\
\text { Protection } \\
\text { Devicesc } \\
(1982 \$)\end{array}$ \\
\hline Temporary Shelter & 24.1 & 330 & 75 \\
\hline Missed Work & 13.1 & 87 & 59 \\
\hline Extra Food Costs & 11.4 & 33 & 22 \\
\hline Demolition & 0.9 & 13 & 8 \\
\hline Legal Expenses & 1.3 & 10 & 7 \\
\hline Transportation & 3.6 & 6 & 5 \\
\hline Emotional Counseling & 11.2 & 15 & 3 \\
\hline Child Care & 1.7 & 2 & 2 \\
\hline Other & 4.4 & 33 & 29 \\
\hline A11 Types $d$ & 29.4 & 529 & 210 \\
\hline
\end{tabular}

aThe original estimates stated in early 1977 dollars, were developed by Princeton University and Mathematica Policy Research, Inc. for the Federal Emergency Management Agency, as reported by Michael J. Munson and James $\mathrm{C}$. Ohls in Indirect Costs of Residential Fires, Federal Emergency Management Agency, FA-6, April 1980 (U.S. Government Printing office: 1980), pp. 24-26. The estimates were adjusted to 1982 dollars by application of the Consumer Price Indices for January 1977 of 175.3 and for October 1982 of 294.1 (U.S. Department of Labor CPI Information Service, November 1982).

bExpenses for medical care and funerals have been omitted here. They are assumed to be accounted for in the amounts quoted in section 3.2 .1 for the respective values of deaths and injuries averted.

CWeighted average over all fires, including those not involving indirect losses.

d29.4 percent of all residential fires had at least one of these components. 
Table 10. Estimated Impact of Sprinklers on Indirect Fire Costs in One- and Two-Family Houses

Average Indirect Costs Per Fire Total Cost Out-of-Pocket

(1982 \$) (1982\$)

(1) Amount Estimated Under Existing

529

210

Use of Fire Protection Devices ${ }^{a}$

551

218

(2) Amount Assuming No Use of Smoke Detectors nor Sprinklers ${ }^{b}$

163

65

(3) Amount Assuming Use of Sprinklers but No Detectors ${ }^{b}$

431

171

Detectors but No Sprinklers b

151

60

Detectors and Sprinklers $b$

Percentage Decrease in

Indirect Costs (\%)

(6) Condition 1: No Detector/Sprinkler

70 System

(7) Condition 2: Detector/Sprinkler System

65

\footnotetext{
aTaken from table 9.

bEstimated trom tables 8 and 9.
} 
The present value benefits of reducing total indirect costs are estimated to be $\$ 45$ under Condition 1 , and $\$ 33$ under Condition 2; i.e.,

Condition 1: No Detector/Sprinkler System

$\bar{C}=(.70)(.00856)(\$ 551)(13.765)=\$ 45.45$.

Condition 2: Detector/Sprink1er System

$\bar{C}=(.65)(.00856)(\$ 431)(13.765)=\$ 33.02$ 


\subsubsection{Insurance Cost Savings}

A part of the cost of fire insurance premiums constitutes in effect a prepayment of the fire losses which insured parties will on the average incur. That is, part of the insurance costs will be returned to the insured in the event of a loss. The effective cost of fire to the homeowner is the cost of the insurance plus the cost of uninsured losses. In the long-run, this amount can be expected to exceed on the average the cost of insured plus uninsured losses by the cost of underwriting and related transaction costs. The loss portion of the insurance rate is that part based on the degree of risk. Homeowners tend to insure even when the loss portion of the rate is quite small in order to protect themselves from two types of risk: having fire costs above the average, and having them sooner than the average.1

Insurance companies typically offer reductions in homeowner's insurance premiums of about two percent for houses with smoke detectors to reflect a lower risk of loss. The Insurance Services office (ISO), an advisory organization to insurance companies, has developed a rule that calls for an additional reduction of up to 8 percent in homeowner's insurance premiums for a sprinkler system providing partial coverage, and up to 13 percent for one providing full coverage, depending on underwriter judgment regarding the

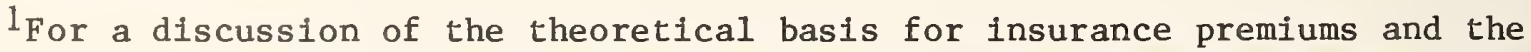
strategy of private risk pooling, see Douglas C. Dacy and Howard Kunreuther, The Economics of Natural Disasters (New York: The Free Press, 1969); and Guido Calabresi, The Costs of Accidents; A Legal and Economic Analysis (New Haven: Yale University Press, 1970).
} 
reliability, maintainability, and performance of the system. The ISO Rule calls for reductions in premiums on dwelling fire policies of up to 10 percent for partial coverage, and up to 20 percent for full coverage, again depending on underwriter judgment. For a tenant's policy on contents, the 8 percent and 13 percent recommended maximum reductions apply. At the time of this study, the rule had been approved in 37 States. 1

The ISO recommendation reflects the results of a report by the Ad Hoc Insurance Committee on Residential Sprinklers, which found in a controlled experiment a 77 percent reduction in the damage losses subject to insurance claims for a sprinklered house as compared to a counterpart nonsprinklered house. 2

At the time of the study, however, the response of insurance companies in adopting this recommendation appeared limited. Discussions with local Maryland representatives of several large insurance companies revealed no available discounts for residential sprinklers. Furthermore, it was suggested that there might be a requirement for special coverage of the sprinkler system for the risk of accidental discharge, offsetting to some extent any future premium reduction. However, the ISO recommendation does not include a penalty

${ }^{1}$ Telephone interview with Dom Yezzi, Insurance Services Office, 160 Water Street, New York, New York, December 20, 1982.

${ }^{2}$ Ad Hoc Insurance Committee on Residential Sprinklers, Report on 1980 Property Loss Comparison Fires, reprinted by the Federal Emergency Management Agency, November 1980, p. 12; and Ralph J. Jackson, "Insurance Incentives for Residential Sprinklers," International Fire Chief, Vol. 47, No. 7, July 1981, p. 11 . 
for sprinkler leakage. It appears that there is a discrepancy between the public's perception of the significance of sprinkler system leakage and the empirical evidence of leakage in commercial and industrial applications. One of the studies undertaken shows, for instance, that over a six-year period sprinkler-related incidents were responsible for only about 12 percent of the total water damage associated with the buildings studied.l

In short, the estimate of sprinkler benefits from reduced fire insurance premiums appears at this time to be tentative, at least in some regions of the country. Realization of this type of benefit by the homeowner who installs a system today is dependent on the responsiveness of the State and insurance companies to the recommendations of the ISO and to test results. A substantial period of time may be required for insurance actuaries to accumulate sufficient empirical data from real world experience to calculate appropriate discounts for sprinklers. And, according to one source, there is a large degree of "arbitrariness and subjectivity" in insurance rate-making, such that changes in risk data do not necessarily lead to corresponding rate changes. $^{2}$ If this is the case, field validation of the very favorable test

\footnotetext{
${ }^{1}$ Walter W. Maybee, "A Brief History of Fire Protection in the U.S. Atomic Energy Commission 1947-1975," A paper presented at the National Fire Protection Association Fall Conference, 1978.

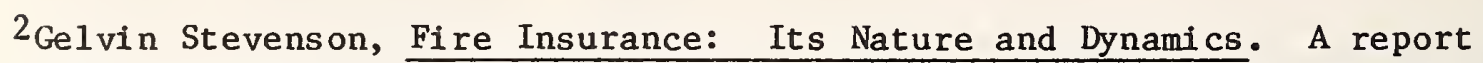
prepared at Princeton University for the U.S. Department of Commerce, National Fire Prevention and Control Administration, October 1978, pp. 75-77.
} 
results for sprinkler performance may not be sufficient to induce significant discounts in fire insurance premiums. 1

With the foregoing caveats and cautions, the base-case analysis assumes a 13 percent reduction in homeowner's insurance premiums, a 20 percent reduction in premiums for dwelling fire policies, and a 13 percent reduction in the premiums for tenant's contents insurance. Break-even analysis solves for the percentage discount in premiums needed to equate benefits and costs, other factors held constant.

A premium cost basis is needed in order to calculate the value of the assumed discount. Fire insurance premiums for homeowner policies depend on the construction of the dwelling, the type of occupancy, the type of structure, and the fire protection class. The fire protection class rating is based on the level of public protection, which is measured according to indices of municipal fire prevention capabilities. From the indices, an overall public protection rating is assigned to a region or municipality. ${ }^{2}$ There are 10 protection classes (1-10), plus categories for "Rural Protected" and "Unprotected." A "Class 1" rating usually designates a city with a we11-equipped fire department, staffed by full-time, paid, professional fire

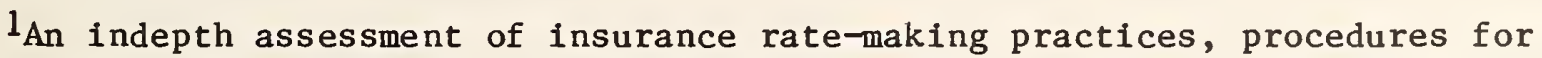
incorporating new technological information into the rate structure, and the degree of adoption by companies of the ISO recommendation for discounts for sprinkler was beyond the scope of this study. An additional insurance issue not addressed here is the possible need for indemnification of sprinkler companies against liability for losses suffered in sprinklered houses (Society of Fire Protection Engineers, SFPE Bulletin, December 1980)

${ }^{2}$ Gelvin Stevenson, Fire Insurance: Its Nature and Dynamics, pp. 15 and 64.
} 
fighters. Insurance companies refer to tables of regional and municipal fire protection classes in establishing the premium for a given house. According to an agent for a major insurance company, the assignment of a fire protection class rating to a municipality or region, once established, is relatively insensitive to changes in the number of households served by a fire department within that municipality or region. (This information is employed as an assumption in section 3.2 .5 in connection with estimating potential municipal cost savings from tradeoffs between community fire protection services and residential sprinklers.)

In light of the factors that influence insurance rates, it is not surprising to find substantial variation in them. A 1976 compilation, by State and type of protection, of average property insurance costs for $\$ 20,000$ of coverage for one- or two-family dwellings of masonry or masonry veneer construction inside the city limits of a municipality with a Class 3 fire protection rating, was used to derive the high, low, and mean insurance rates in 1982 dollars shown in table 11 .

To develop estimates of the annual insurance premium, the estimated mean rates in table 11 are applied to an assumed structure value of $\$ 71,300^{l}$ and to a contents value of $\$ 50,000$. (The mean rate for the homeowner's policy is assumed to cover structure and contents combined and is applied only to structure value to develop an estimate of annual premium.)

\footnotetext{
$1_{\text {The }} 1982$ average sales price for new houses sold in the U.S. was $\$ 83,900$ (from U.S. Department of Commerce, Construction Review, May-June 1983). This price is reduced by 15 percent to adjust for land costs.
} 
Table 11. Estimated Property Insurance Rates in the U.S. for One -or

Two-Family Dwelling and Contentsa

(Inside City Limits, Class 3 Fire Protection Rating, Masonry Veneer Construction)

\begin{tabular}{ccc} 
Cost Per Thousand Dollars of Coverage & M \\
$(1982)$ & High & Mean \\
\hline Low & 7.23 & 2.96 \\
1.02 & 9.69 & 3.47 \\
1.11 & & \\
0.85 & 4.87 & 2.38
\end{tabular}

aDerived from 1976 data for 40 States giving the average cost of policies in each state for $\$ 20,000$ of coverage, as reported by Gelvin Stevenson, Fire Insurance: Its Nature and Dynamics. The costs were converted to costs per thousand dollars of coverage and adjusted from 1976 dollars to 1982 dollars by applying the consumer price indices for property insurance for January 1977 of 238.6 and for October 1982 of 405.8 (U.S. Department of Labor). The adjusted lowest and highest values among the forty provided are shown to indicate the large degree of variation. The adjusted mean value is used in the sensitivity analysis. The data base from which these estimates were developed reflected substantial deviation in type and condition of coverage and the data are not entirely comparable. For example, the high end of the range for homeowner's and residential commercial insurance are derived from rates in states that did not have separate rates for masonry and frame construction.

${ }^{b}$ It should be recognized that the cost per $\$ 1,000$ of coverage tends not to be a linear function of the total amount of coverage, as is implicitly assumed in applying the above rates to larger amounts of property value. However, the adjusted average rates shown above correspond quite closely to actual quotations obtained by the study for homeowner's and residential commercial policies for $\$ 85,000$ of coverage in suburban Maryland. 
For the homeowner/occupant, the present value benefit of a discount in insurance premiums due to sprinklers is calculated as follows:

Condition 1: No Detector/Sprinkler System

$$
\overline{I N}=i d_{h}\left(i n_{h} \cdot I S\right) \quad U P W_{d, n, e}^{*}
$$

Condition 2: Detector/Sprinkler System

$$
\overline{\mathrm{IN}}=i d_{\mathrm{h}}\left(1-i d_{d}\right)\left(i n_{\mathrm{h}} \cdot \mathrm{IS}\right) \quad \mathrm{UPW}_{\mathrm{d}, \mathrm{n}, \mathrm{e}}^{*}
$$

(Definitions follow equation 43.)

For the owner of a rental house, the procedure for estimating the present value benefit of discounts in insurance premiums due to sprinklers is as follows:

Condition 1: No Detector/Sprinkler System

$$
\overline{I N}=\left[i d_{s}\left(i n_{s} \cdot I S\right)+i d_{c}\left(i n_{c} \cdot I C\right)\right] U P W_{d, n, e}^{*}(1-t)
$$

Condition 2: Detector/Sprinkler System

$$
\begin{aligned}
\overline{I N}= & {\left[i d_{s}\left(1-i d_{d}\right)\left(i n_{s} \cdot I S\right)+i d_{c}\left(1-i d_{d}\right)\left(i n_{c} \cdot I C\right)\right] U P W_{d, n, e}^{*} } \\
& (1-t),
\end{aligned}
$$

where,

$$
\begin{aligned}
& \overline{\mathrm{IN}}=\text { present value to the homeowner (owner/occupant or owner of a rental } \\
& i d_{h}=\text { the fractional discount in premiums for homeowner's insurance for a } \\
& i d_{s}=\text { the fractional discount in premiums for dwelling fire insurance } \\
& \text { for a sprinklered house, } \\
& \text { id } d_{d}=\text { the fractional discount in premiums for homeowner's insurance for } \\
& \text { a house equipped with a smoke detector, } \\
& i_{h}=\text { the insurance rate per } \$ 1,000 \text { of homeowner's coverage, } \\
& \text { in }_{s}=\text { the insurance rate per } \$ 1,000 \text { of fire coverage on the structure, }
\end{aligned}
$$


IS = the amount of insurance coverage on the structure,

id $_{c}=$ the fractional discount in premiums for tenant's insurance in a sprinklered house,

in $n_{c}=$ the insurance rate per $\$ 1,000$ of coverage on the contents,

IC = the amount of insurance coverage on contents, and

$t=$ the marginal income tax rate of the owner of a rental house.

For an owner/occupant purchasing a homeowner's policy which includes coverage of both structure and contents, inc and IC need not be separately assessed. For an owner of a rental house, any discount on the tenant's contents insurance is included as a benefit to the owner of the house, reflecting the assumption of an equivalent higher rent to the owner for benefits to the tenant.

Using the above assumptions and the upper end of the range of recommended discounts, the present value benefits to an owner/occupant of reduced insurance premiums over 30 years, under Condition 1 , are $\$ 378$; i.e., Condition 1: No Detector/Sprinkler System

$$
\overline{\mathrm{IN}}=(.13)(2.96)(\underset{1,000}{\stackrel{71,300}{\longrightarrow}}(13.765)=\$ 377.66
$$

\section{Condition 2: Detector/Sprinkler System}

Under Condition 2, where there is an initial 2 percent reduction in premiums to reflect smoke detectors, present value benefits of the additional reductions to reflect sprinklers are $\$ 370$. 
To the owner of a rental house, present value benefits, under Condition 1 , are $\$ 536$

Condition 1: No Detector/Sprinkler System

$$
\overline{\mathrm{IN}}=(.20)(3.47)\left(\frac{71,300}{1,000}\right)+(.13)(2.38)\left(\frac{50,000}{1,000}\right)(13.765)(1-.4)=\$ 536.42
$$

Condition 2: Detector/Sprinkler System

Under Condition 2, where reductions due to smoke detectors are first taken into account, present value benefits due to the addition of sprinklers are $\$ 526$.

(The difference between estimated savings for the owner/occupant and the owner of a rental house reflects the difference in applicable insurance rates and the fact that rental income is taxable to the owner, while insurance costs are a tax deductible expense for the owner.)

By their payment of insurance premiums, individual property owners exchange relatively small certain costs for protection against uncertain losses. To avoid double counting of homeowner benefits, it is necessary to coordinate the assumptions regarding direct (property) losses (section 3.2.2) and insurance cost reductions. That is, the inclusion of insurance cost savings means that the loss reductions should be lessened to reflect the assumption of fire insurance. This was done in sections 3.2 .2 and 3.2.3. For the base-case analysis, it is assumed that all but 20 percent of property losses are covered by insurance, as well as a substantial share of indirect costs. Fire insurance also often includes death and injury benefits in variable amounts, but the value for life and injury are assumed to be over and above any insurance reimbursements, and no additional adjustment is made. 


\subsubsection{Municipal Cost Savings in Fire Protection Services (Potential Property Tax Savings to the Homeowner)}

In 1982 the more than 18.8 thousand municipalities in the U.S. are estimated to have spent about $\$ 5.7$ billion on fire protection. This was an average expenditure of about $\$ 300$ thousand per municipality.1 With increasing budgetary pressures, many municipalities are seeking ways to cut costs without unacceptable cuts in service. Some are looking to residential sprinkler systems as one possible way to reduce, stabilize, or control the growth in municipal fire protection costs. For example, equipping the houses of a new development with sprinklers might reduce or eliminate the need for increased municipal fire protection capacity. The resulting savings might be passed back to homeowners in the form of lower property taxes or used by the municipality for other purposes. ${ }^{2}$

The tradeoff between residential sprinklers and municipal fire protection services is highly dependent on local conditions, and the estimate of an "average" value of potential municipal cost savings from sprinklers is uncertain and very rough at best. The approach used here is (a) to estimate the cost of providing fire protection to a new residential development by building, equipping, and staffing a fire station (or adding to an existing

$1_{\text {The }} 1982$ dollar expenditure is estimated by adjusting the 1978 expenditure as reported in the 1980 Statistical Abstract to 1982 dollars. The number of municipalities is as reported for 1977 .

${ }^{2}$ An issue which may arise in this context but which is not addressed in this study is the question of equity in matching of incidences of tax changes with incidences of homeowner costs. 
fire station), and (b) to assume that the new station (or addition) need not be built, equipped, and staffed if all houses in the development are equipped with sprinklers. It is assumed that the existing level of fire protection services will continue to be adequate if the new houses are equipped with sprinklers because the necessary response time to these houses will be reduced for most fires. 1 The fire department cost savings are interpreted as community benefits. The cost savings divided by the number of houses in the new development are interpreted as potential homeowner benefits--"potential" because they are dependent on the action taken by the municipal government. The costs of the fire department are based on the following highly simplified assumptions regarding the area and houses served:

(1) The size of the "New Development" corresponds to the size of the area to be served by a new fire station, and comprises 5.85 square miles. This area was derived according to a theoretical approach depicted in Figure 4.2

\footnotetext{
lit should be recognized, however, that if the assumed change were to alter the community's fire protection class rating, the reduction in community fire protection costs could be more than offset by higher insurance rates to homeowners. An example of the effect of fire protection services on insurance rates was given in a recent article: "... in an area with no fire protection, which insurance people in New England call 10-F, the annual insurance premium for an average $\$ 20,000$ home would be $\$ 96.60$. The annual premium for the same house in an area rated $5-C$ would be $\$ 41.80$, or an annual (difference) of $\$ 54.80$. (Chief Edmund Stone, "How to Estimate Value of Department Rating on Insurance Savings," Fire Engineering, March 1978). However, as was noted in section 3.2.4, there may be substantial leeway in changing the ratio of fire protection services to households, without affecting the fire protection call rating of the community.

${ }^{2}$ The Rand Corporation, Fire Department Deployment Analysis: A Public Policy Analysis Case Study, Ed. W. E. Walker, J. M. Chaiken, and E. J. Ignall (New York: North Holland, 1979).
} 
Figure 4. Determining the Area of the "New Development" for Which Fire Station Costs Will be Avoideda

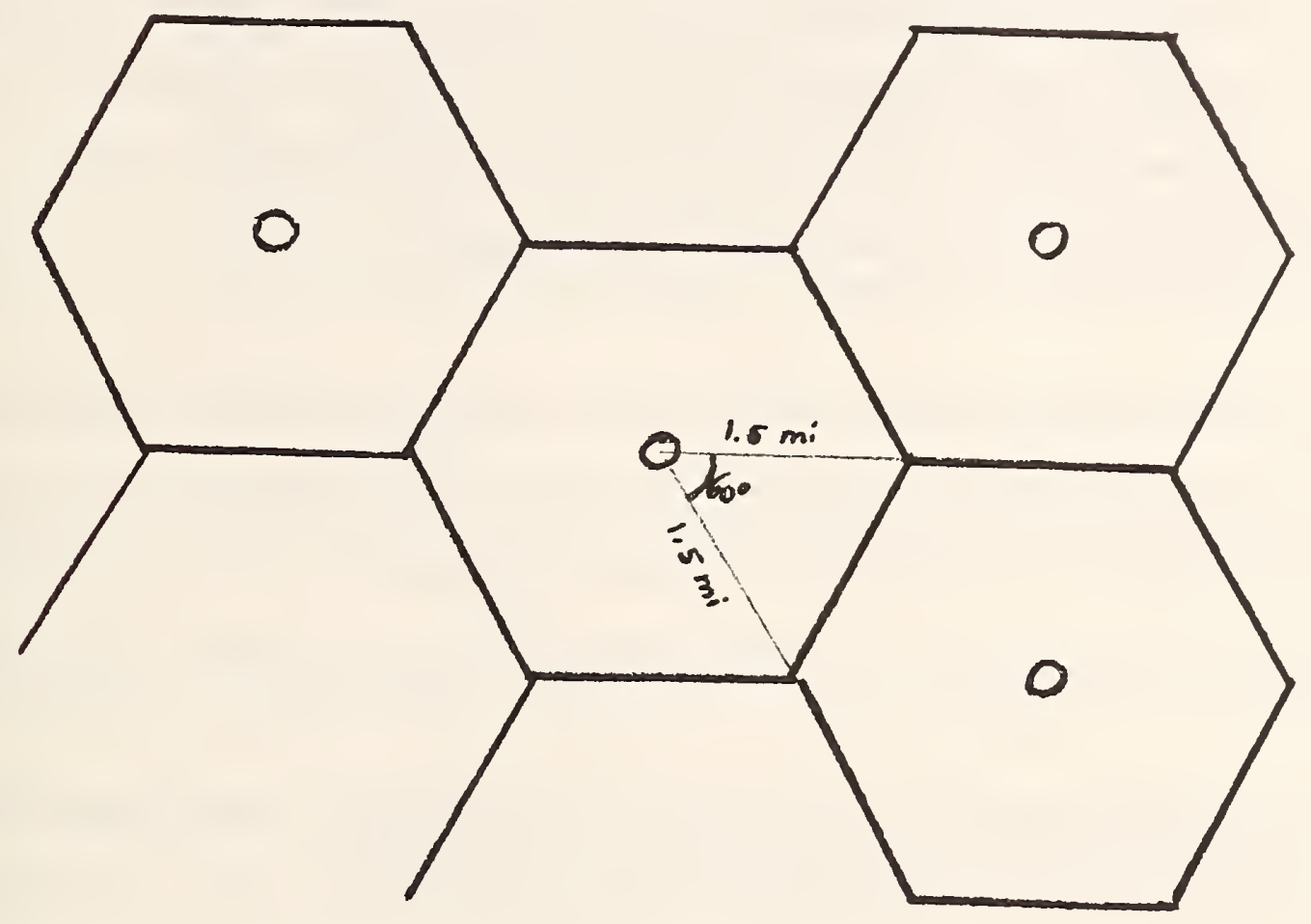

according to a theoretical approach to fire company location (as described by the Rand Corporation in Fire Department Deployment Analysis: A Public Policy Analysis Case Study), a hexagon shape was assumed for the area--the optimal shape for efficiently utilizing a fire station. And, a maximum distance of a house from the station of $11 / 2$ miles was assumed based on a required flow rate. The area of the hexagon was then determined.

o = Engine Company 
(2) The area is assumed to contain 2,106 people and 642 houses. The population density was established according to the average density of people per square mile inside Standard Metropolitan Statistical Areas (SMSA's) in 1970, the latest year for which these data were found.1 Using the average SMSA density of 360 people/sq. mile and multiplying by the number of miles results in an estimate of 2,106 people in the New Development (i.e., 360 people/sq.mile $5.85 \mathrm{sq} \cdot$ mile $=2,106$ people.

The number of households was derived by relating the number of people per household to the number of people. The 1980 average number of people per family was reported as 3.28 .2 Assuming single-family houses, the number of houses is found as 642 (i.e., 2,106 people/3.28 people/family = 642 families).

The cost of the fire station structure (including site preparation, architects and engineers fees, supervision and administrative overhead, and materials and labor, but excluding land costs) was developed by the General Estimate Method of construction cost estimating, according to the following building specifications: ${ }^{3}$

11981 Statistical Abstract, p. 15.

${ }^{2}$ Ibid., p. 42.

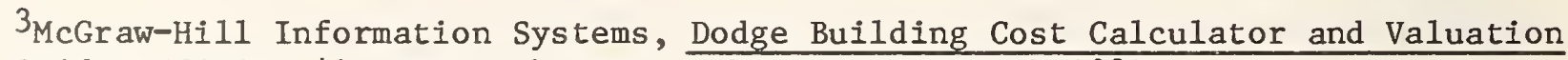
Guide, Edition 41, New York, New York, January-March 1981. 
Construction: Masonry Wall

Quality: Good

Structure: Reinforced concrete foundation, footings, walls and slabs. Exterior walls: face brick and block with stone trim and finish. Good quality wood or metal sash. Interior masonry bearing walls with plaster finish. Structural steel floor and roof decking with concrete fill. Built-up roof and insulation. Resilient flooring and ceramic or quarry tile. Suspended acoustical tile ceiling in office area. Remaining areas dry-wall or plaster.

Plumbing: Locker and shower rooms. Water coolers. Utility and service sinks.

Heating and Ventilation: Boiler - oil or gas fired low pressure steam or hot water heat. Suspended heaters in truck area.

Electrical: Special wiring and circuitry for alarm systems, extensions, outlets, clock, trouble and reading lights.

Functional Areas: Apparatus and truck parking areas, hose drying, storage, mechanical work area, watch room, office and living area, lounge, dormitory, and kitchen.

Size: 4,000 square feet.

The basic cost data in the Dodge Building Cost Calculator are at a 1970 level, and must be adjusted by cost multipliers for the desired location. For use in this study, the average of the local cost multipliers for $183 \mathrm{U} . \mathrm{S}$. Metropolitan Areas was computed. This figure was 2.3, and its use resulted in costs stated in 1981 dollars. To adjust the cost to 1982 dollars, the price indices for State and local government purchases of structures for 1981 (230.3) and the 2nd quarter of 1982 (seasonally adjusted) (235.2) were used, i.e., $(\$ 111,520)(2.3)\left(\frac{235.2}{230.3}\right)=\$ 261,953$. The resulting estimate, in 1982 dollars and rounded to the nearest hundred, is $\$ 262,000$. 
Land costs, estimated as 20 percent of total cost (building and land), are $\$ 65,500$ in 1982 dollars, rounded to the nearest hundred (i.e., $\$ 261,953+$ $.2 \mathrm{TC}=\mathrm{TC}$ and $.2 \mathrm{TC}=\$ 65,488)$.

Structure and land costs combined are estimated to be $\$ 327,500$, i.e., $\$ 262,000$ $+\$ 65,500=\$ 327,500$. The cost of operating the station to supply fire services (including costs of equipment and manpower, but not the building) is developed from the per capita supply costs reported for five western cities (and, hence, may not be typical for the U.S. as a whole). The reported costs, in adjusted 1982 dollars, ranged from a low of $\$ 19.59 /$ person/year to $\$ 41.27 /$ person/year, and averaged $\$ 32.04 /$ person/year.1

Using constant dollar costs and a assumed 6 percent municipal discount rate, the present value costs of supplying fire services to the new development over 30 years is estimated to be $\$ 928,800$ in 1982 dollars, rounded to the nearest hundred (i.e., $(\$ 32.04)(13.765)(2,106)=\$ 928,810.44)$.

Summing the supply costs and the building costs yields an estimated total present value cost of providing fire services to the new community by conventional means of $\$ 1,256,300$ in 1982 dollars, (i.e., $\$ 327,500+\$ 928,800=$ $\$ 1,256,300)$. This is the estimated benefit to the municipality of not

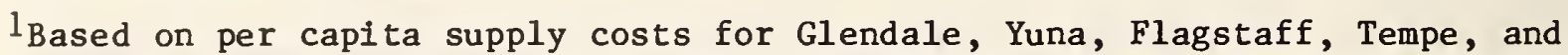
Phoenix as reported by Roger Aklbrandt in "Efficient Output of a Quasi-Public Good-Fire Services" (Ph.D. Dissertation, Department of Economics, University of Washington, 1972, table A.). The supply costs, stated in 1971 dollars, were adjusted to 1982 dollars by application of the price indices for State and local government purchases of goods and services.
} 
building, equipping, and staffing a fire station to serve the new development.

The owners of the sprinklered houses would derive a corresponding benefit only if the municipality shared this savings through, for example, lowered local taxes. Assuming an annual pass-through of the present value savings amortized over 30 years at a real discount rate of 6 percent from the municipality to the homeowners who install sprinklers, the annual tax rebate, or tax reduction, would be $\$ 143$ per household (i.e., $(\$ 1,256,000)(0.073) \div 642$ $=\$ 142.82)$. For both an owner/occupant and an owner of a rental house, the estimated after-tax present value benefit $(\overline{\text { MTS }})$ is $\$ 1,179$ (i.e., $\overline{\text { MTS }=}$ $(\$ 142.82)(13.765)(1-0.4)=\$ 1,179.49)$. This takes into account the fact that local taxes are a tax deductible expense in computing Federal income taxes for owner-occupied and rental houses.

\subsubsection{Governmental Incentives}

To encourage a type of action or behavior deemed in the public interest, local, State, and Federal Governments sometimes provide subsidies to lower the effective cost of the desired action to the individual and, thereby increase its likelihood of occurrence. For example, governmental incentives have been made available in recent years to promote homeowner investment in energy conservation and alternative energy sources. 1

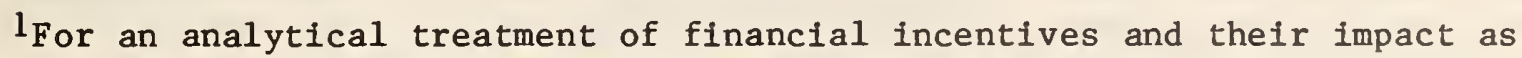
applied to solar energy investments, see Rosalie T. Ruegg, Evaluating Incentives for Solar Heating, National Bureau of Standards, NBSIR 76-1127, September 1976. 
Financial incentives may take the form of income tax credits, increased allowable income tax deductions, direct cash subsidies in the form of grants and cost-sharing arrangements, special low interest loans and loan guarantees, and waivers or reductions in property taxes that would otherwise accrue.

Although there are currently no incentives offered by the Federal Government to homeowners who purchase sprinkler systems, there is a possibility that such incentives may become available in the future, and, hence, the potential impact of incentives is of interest to the study. As of the time of this study, pending incentive legislation is limited to tax credit provisions for profit-making establishments which install sprinklers. For example, Senate Bill 878, introduced by Senator Howard Cannon ( $D-N V$ ) would have allowed a 20 percent tax credit for sprinklers installed in properties eligible for the regular investment tax credit. 1

At least one state, Alaska, has enacted a law which exempts from taxation $2 \%$ of the assessed value of any structure that is protected with a "fire protection system." 2

For the purpose of the base-case analysis, no governmental incentive is included. However, the value of a tax credit necessary to cause a break-even investment outcome for the homeowner is calculated for several different

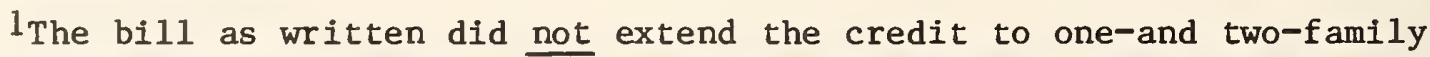
residences, a point that has been inaccurately reported in the press (see, for example, "Dousing Home Fires," The Washington Post, July 10, 1982). [Telephone interview with staff assistant to Senator Howard Cannon, Dec. 10, 1982.] Several House Bills (HR.1958 and HR.73795) contained similar provisions. [U.S. Legislative Status Office, U.S. Capitol].

${ }^{2}$ Reported by John A. Viniello, "An 0ld Idea With a New Technology," Grinnel Fire Protection Systems Company, Inc. (Undated). 
conditions in section 3.3. Also, the sensitivity analysis includes the case of a 20 percent Federal income tax credit, plus the local incentive of eliminating the estimated value of the higher property taxes that are included in the base-case analysis. The value of the tax incentive is based on the assumption that the total cost of purchasing and installing the system is eligible for the credit. Using the $\$ 1,718$ estimated cost of a system with $1 / 2$ inch diameter polybutylene piping (table 5) and assuming receipt by the homeowner of the credit at the end of the year in which it is installed results in an estimated present value benefit of $\$ 324$; i.e.,

$$
\overline{\mathrm{GI}}=(\$ 1,718)(.2)(.943)=\$ 324.01,
$$

where $\overline{\mathrm{GI}}=$ present value of a governmental incentive.

Note that the value of this benefit is equivalent for the owner/occupant, the owner of a rental unit, as well as for the builder/developer, because it constitutes a direct reduction in the investor's tax liability by the designated amount.

\subsubsection{0ther Potential Benefits}

A different type of incentive that may be offered in some localities to builders/developers who install sprinkler systems is a relaxation in local codes to allow increased building density and less fire-resistant construction. By reducing land and construction costs, these allowances constitute benefits to the builder/developer who installs sprinkler systems. To the extent that the resulting cost reductions are passed through to purchasers of the houses, they are also benefits to the homeowner. However, the increased housing density that may result could give rise to "disbenefits" 
that are partially offsetting of the cost reduction benefits. The changes in construction requirements may also have other effects which affect homeowner satisfaction with the house. Because of the large degree of uncertainty about the impact of these types of code changes on the homeowner, they are not included in this estimation of homeowner benefits and costs.

Another potential benefit to the homeowner that is sometimes cited is a higher resale value of the sprinkler-equipped house. That benefit is treated implicitly in this study in conjunction with the assumed life of the system. In the base-case analysis, it is assumed that the system gives service for 30 years and that ownership is maintained over that 30 year period.

\subsubsection{Summary of Benefits Estimates}

The preceding seven sections, 3.2.1 through 3.2.7, have discussed benefit estimation for reduced risk of death and injury and direct and indirect costs, insurance cost savings, reduced costs of municipal fire protection services, governmental incentives, and other potential benefits. Benefit estimates have been developed for the owner/occupant of a house and the owner of a rental house. Table 12 summarizes the estimates of current and potential benefits. 
Table 12. Summary of Benefits Estimates ${ }^{a}$

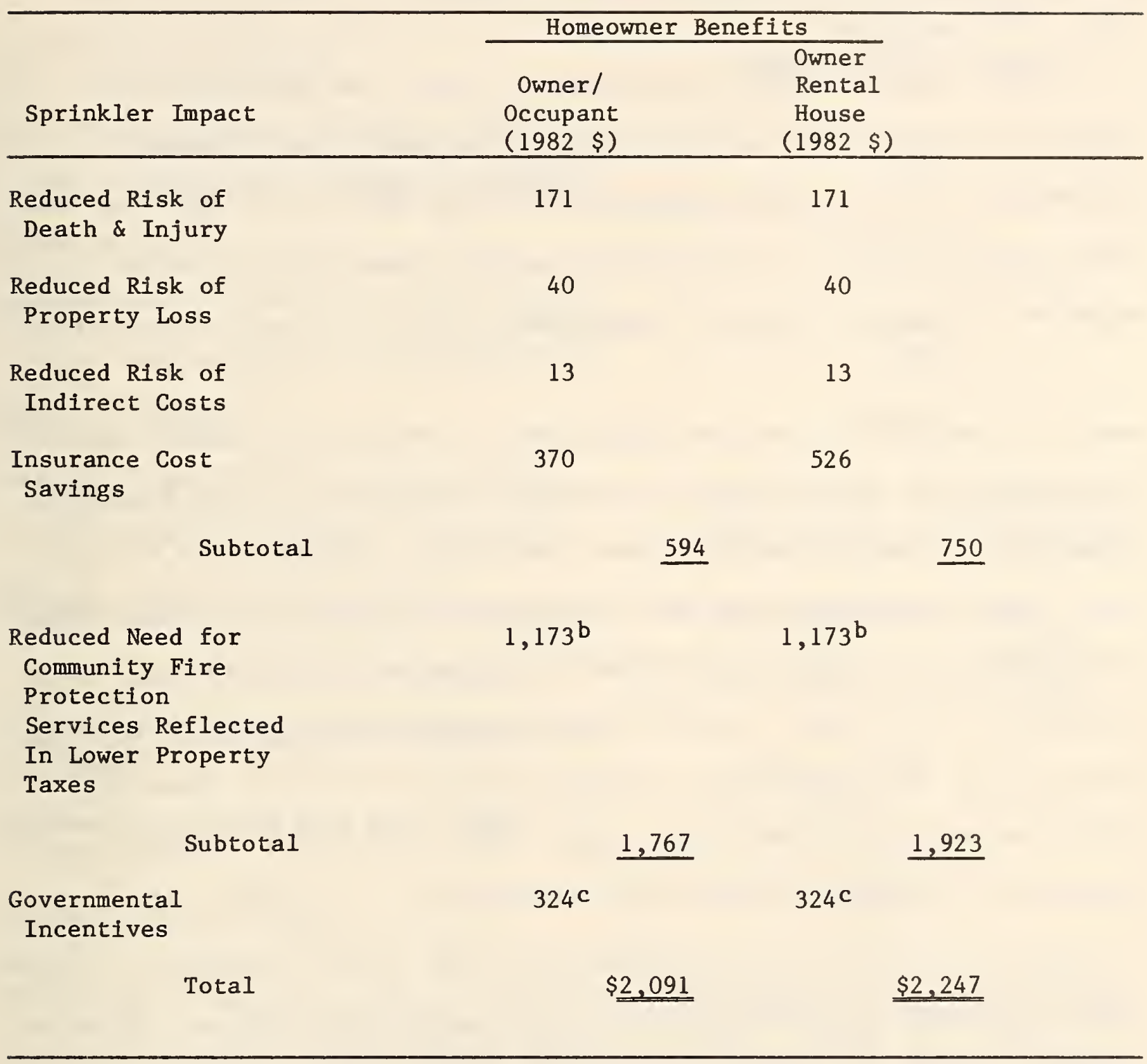

asumarized from sections 3.2.1 through 3.2.7.

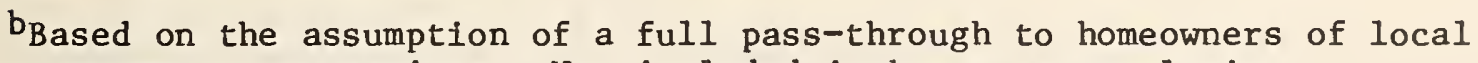
government cost savings. Not included in base-case analysis.

$\mathrm{c}_{\text {Based on }} 20$ percent tax credit not currently available. Not included in base-case analysis. 


\subsection{Case Study Results}

\subsubsection{Base-Case Results}

This section brings together the estimates of costs from section 3.1 and benefits from section 3.2 and enters them in the benefit-cost framework. Nine benefit-cost case studies demonstrate how the model can be used, and the results provide insight to the potential economic feasibility of residential sprinkler systems under specified conditions.

Table 13 summarizes the data and assumptions for benefits developed in section 3.2, and table 14 those for costs developed in section 3.1. These data and assumptions are used in the first case illustration, referred to as the base case. Table 15 summarizes the data and assumptions used in the other selected case illustrations, which are presented in the context of sensitivity analysis of the base case. Table 16 lists the values of economic parameters used in all of the illustrations. (Notes to each of the tables summarize briefly the basis for selecting the values shown. For a more in-depth explanation, the reader can refer back to sections $2.3,3.1$ and 3.2. )

Table 17 gives the net benefits results for the base-case study. It may be seen that in this illustration the sprinkler system is not a cost-effective investment. Costs are estimated to exceed benefits by nearly $\$ 1,500$ in present value dollars over a 30 year period.

Table 18 shows the break-even values of critical parameters that would be required to make the sprinkler system of table 17 minimally cost effective, with other variables at their base-case values. For example, with no municipal cost reductions or special incentives, the value placed on life would have to be 
Table 13. Summary of Data and Assumptions for Estimating Benefits for the Base-Case Illustration

Probability of Fire $P(F)^{a}$

Prior Protection State

Probability of Death Given Fire $P(D \mid F)^{b}$

With Smoke Detector But Without Sprinklers

With Smoke Detector and With Sprinklers

Value per Lifec

Probability of Injury Given Fire $P(I \mid F)^{b}$

With Smoke Detector But Without Sprinklers

With Smoke Detector and With Sprinklers

Value per Injuryc

Average Direct Property Loss Per Fire With Smoke Detector/Without Sprinklers With Smoke Detector/With Sprinklers

Average Indirect Cost Per Fired With Smoke Detector/Without Sprinklers

With Smoke Detector/With Sprinklers

Insurance Premium Discount--Homeowner's Policye

Homeowner's Premium Rate per $\$ 1,000$ Coveragef

Insured Value of Houseg
.00856

Smoke Detectors Present

.00390

.00146

$\$ 500,000$

.02546

.01436

$\$ 20,000$

$\$ 2,626$ (total) $\$ 525$ (uninsured) \$924 (tota1) \$185 (uninsured)

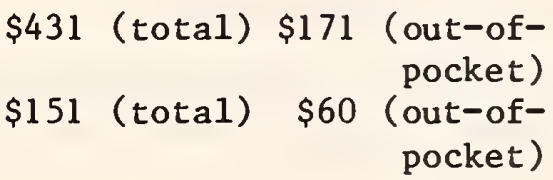

$13 \%$

a Number of reported fires in one- and two-family houses in the U.S. in 1981 divided by the number of one- and two-family houses in the U.S. housing stock. bstimated from reported data and simulated results based on laboratory and field fire tests for single-family dwellings, as described in Alan Gomberg, et al., A Decision Model for Evaluting Residential Fire-Risk Alternatives, NBSIR, in preparation 1984. (Implicit in the probability estimate is an occupancy level of the house equal to the $1981 \mathrm{U} . \mathrm{S}$. average for houses in which people were killed or injured by fire.)

$\mathrm{c}_{\text {Based on }}$ assumptions made in section 3.2 .1 .

d Derived from estimates reported by Michael J. Munson and James C. Ohls, Indirect Costs of Residential Fires, by assuming that indirect costs are affected by sprinklers proportionately to the impact of sprinklers on direct costs.

epercentage discount recommended to insurance companies by the Insurance Services Office (ISO), as reported by the Ad Hoc Insurance Committee on Residential Sprinklers.

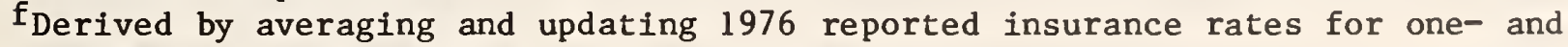
gtwo-family dwellings from 40 U.S. States.

Mean sales price of all new houses in the U.S. $(\$ 83,900$ in 1982), less a $15 \%$ adjustment for land costs.

Note: All monetary values are in 1982 U.S. dollars. 
Table 14. Summary of Data and Assumptions for Estimating Costs for the Base-Case Illustration

House Occupancy

Sprinkler System Contract Costa

Piping

Installed Cost/L.F.

Number of Fittings

Installed Cost of Fittings

Fire Sprinkler Kit, Installed

other Costs

Total System Cost

Operating Costs

Water Charge ${ }^{b}$

Probability of Properly Functioning Systemc

Activation of System ${ }^{d}$

Maintenance, Repair and Replacement Costs Annual Routine Inspection by Plumber Hourly Wage Ratee

P1umber

Replacement of Sprinkler Heads $\mathrm{f}$

Yearly Replacement Rate, Years 1-10

Yearly Replacement Rate, Years 10-20

Yearly Replacement Rate, Years 20-30

Property Taxg

Initial Assessment Basis Contract Cost

Ending Assessment Basis Contract Cost
Owner-Occupied

$1 / 2$ " polybutylene - 205 L.F.

$\$ 2.03$

30

$\$ 149$

$\$ 1,120$

$\$ 33$

$\$ 1,718$

$.00078 d / g a 1$

0.92

Activation of 3 Sprinkler Heads for 30 Minutes

1 hour

$\$ 27.65$

$1 \%$

$1.5 \%$

$2.5 \%$

$(\$ 1,718)$

0

\footnotetext{
a Developed by applying the Component Method of Construction Cost Estimating to a hypothetical system design for a 2-story colonial-type house.

$\mathrm{b}_{\mathrm{U}}$.S. mean marginal price per gallon of water for a household of four.

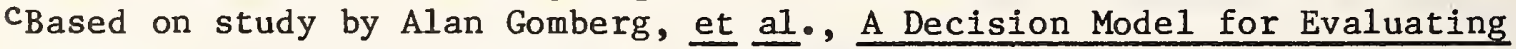
Residential Fire-Risk Reduction Alternatives.

đPessimistic assumption, since normally only one head will activate and activation will not last for 30 minutes.

e $_{U} . S$. average wage rates in cities, including overhead and profit, in 1982 dollars.

fSprinkler heads can be damaged by painting, dust, and water corrosion over time. This replacement schedule allows for replacement of one half of the 21 heads over the system life and assumes failure to be an increasing function of age.

gassumes straight-1ine decline in tax basis.
} 
Table 15. Summary of Data and Assumptions for Other Illustrations

Parameters

Pass-through to Homeowner of Municipal

Cost Savings (New Housing Development)

Geographical Area

Population Densityb

Number of Houses $c$

Fire Station Structure Cost Avoidance ${ }^{d}$

Fire Station Land Cost Avoidance

Equipment and Manpower Cost Avoidance ${ }^{f}$

"Regular" Property Taxes on Capitalized Value of Sprinkler Systems

Federal Income Tax Creditg

Copper Piping (average $\left.11 / 4^{\prime \prime}\right)^{\mathrm{h}}$

Water Demand ("Stand-by") Charge

No Insurance
Assumed Value 
Table 16. Summary of Economic Assumptions Used in Case Studies

Parameter

System Lifea

Study Period

Remaining Value at End of Life

Discount Rateb

Mortgage Ratec

Mortgage Lifec

Inflation Ratec

Homeowner's Marginal Income Tax Rated

Effective Property Tax Rate

Downpayment
Assumed Value

30 Years

30 Years

0

$6 \%$ (real) $11.3 \%$ (nomina1)

$10 \%$ (real) $15.5 \%$ (nominal)

30 Years

$5 \%$

$40 \%$

$2.15 \%$

0

\footnotetext{
aThe life of fast-response sprinkler systems, with polybutylene piping, has not been empirically validated for residential use; however, plumbing systems in houses and sprinkler apparatus in commercial buildings appear to have relatively long lives. The specific choice of a 30 year study period is based on the customary 30 year mortgage lending period for residential housing.

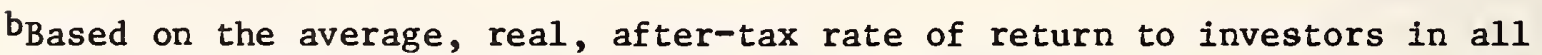
grades of nonfinancial common stock and long-term corporate bonds over recent decades, and the implied discount rate ranging from $5.1 \%$ to $8.9 \%$ for households with incomes between $\$ 35,000$ and $\$ 50,000$, as derived by Hausman.

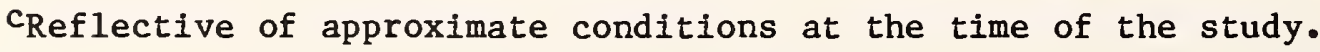

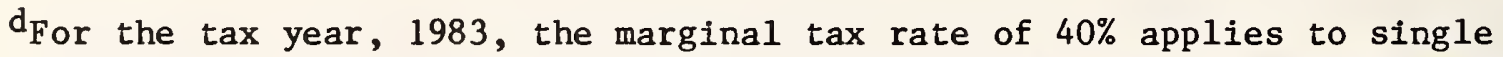
individuals with at least $\$ 34,000$ of taxable income and to married couples with at least $\$ 45,800$.

eThe average effective rate for 30 large U.S. cities in 1978.
} 
Table 17. Base Case: Net Benefits Calculation

Benefits

Deaths and Injuries Averted

Property Losses Averted

Indirect Costs Avoided

Insurance Cost Savings

Total Benefits
Present Value (\$)

171

40

13

370

\section{Costs}

Purchase and Installation Costs
(after taxes and financing)

Operating, Maintenance, Repair, and Replacement Costs

Property Taxes on the System

Total Costs
1,445

420

190

Net Benefits 
Table 18. Base Case: Break-even Analysis

(Note: Assumptions Are Initialized to Base-Case Values After Each Breakeven Calculation)

\begin{tabular}{|c|c|}
\hline $\begin{array}{l}\text { Purchase and Installation Cost } \\
\text { (after taxes and financing) }\end{array}$ & 0 \\
\hline Probability of Fire & .064 \\
\hline $\begin{array}{l}\text { Value of a Life Saveda } \\
\text { (Discounted) }\end{array}$ & \$5 million \\
\hline $\begin{array}{l}\text { Value of a Life Saved Plus } 3.56 \text { Injuries } \\
\text { Averted } \\
\text { (Not Discounted) }\end{array}$ & $\$ 2.6$ million \\
\hline $\begin{array}{l}\text { Average Value of Uninsured Property } \\
\text { Loss Per Fire Without Sprinklers }\end{array}$ & $\$ 19,500$ \\
\hline $\begin{array}{l}\text { Percentage Discount in Homeowner's } \\
\text { Insurance Rate }\end{array}$ & $64 \%$ \\
\hline $\begin{array}{l}\text { Homeowner's Insurance Premium Per } \\
\quad \$ 1,000 \text { of Coverage }\end{array}$ & $\$ 14.64$ \\
\hline $\begin{array}{l}\text { Annual Property Tax Reduction Reflective } \\
\text { of Municipal Cost Savings (Constant } \$ \text { 's) }\end{array}$ & $\$ 92$ \\
\hline $\begin{array}{l}\text { Reduction in Builder's Costs (assuming a } \\
\text { full pass-through to home buyer) }\end{array}$ & $\$ 1,461$ \\
\hline $\begin{array}{l}\text { Federal Income Tax Credit } \\
\text { (as a \% of Initial Purchase and } \\
\text { Installation Cost) }\end{array}$ & $90 \%$ \\
\hline
\end{tabular}

\footnotetext{
aAssumes an occupancy level equal to the $1981 \mathrm{U.S}$. average for houses in which people were killed or injured by fire. Hence, the break-even value would be smaller than that shown for houses with greater than average occupancy or larger for houses with smaller than average occupancy.

${ }^{b}$ According to Approach 2 described in section 3.2.1.

$c_{\text {Tax }}$ reductions in addition to a waiver of property tax on the capitalized value of the sprinkler system.
} 
about $\$ 5$ million in present value dollars or the total value placed on life and injuries averted would have to be about $\$ 2.6$ million in undiscounted dollars. As other examples, the homeowner would have to have a risk over seven times the average rate, or incur about $\$ 19,500$ in uninsured property loss on the average per fire without sprinklers in order for a breakeven outcome to result, all other factors remaining the same.

\subsubsection{Additional Case Results}

Table 19 summarizes the results for eight additional hypothetical case studies to show what happens when the values of key parameters and assumptions are varied from those of the base case illustration.

Columns 1 and 2 of Table 19 show that the combination of a waiver of property taxes on the capitalized value of the sprinkler system and a pass-through to the homeowner of estimated municipal cost avoidance are sufficient, given the other data and assumptions, to eliminate most of the losses. If, in addition, a 20 percent Federal income tax credit is granted, positive net benefits of about $\$ 200$ dollars are estimated.

Columns 3 and 4 of Table 19 show the result of two pessimistic cases. Substantial net losses are estimated for systems using large copper piping and subject to a "water standby fee." These two estimates may be regarded as "worst case results" because piping as large as $11 / 4$ inch would seldom be used throughout a system, and most municipalities probably would not levy a water demand charge. 


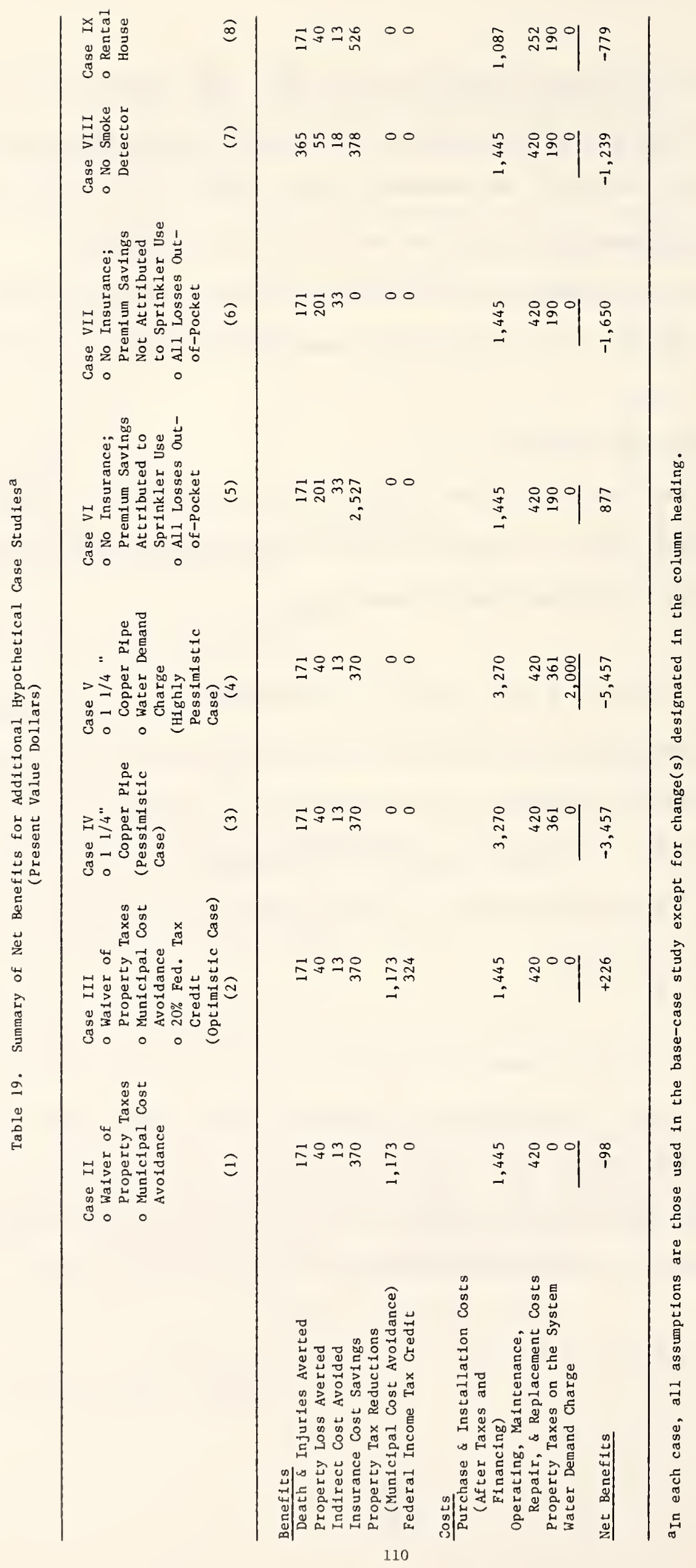


Columns 5 and 6 show estimated results assuming no insurance. Column 5 attributes the cost savings from not insuring, directly to the sprinkler; i.e., the assumption is that the sprinkler reduces the risk of loss to a level that causes the homeowner to accept the risk without insuring. Positive net benefits are estimated. These two cases are unlikely to be widely applicable because most homeowners either are required to carry fire insurance as a condition of obtaining a mortgage loan, or, in any case, do not elect to "self-insure" because they are risk averse. The results reflect primarily the fact that fire dwelling insurance is not cost effective, on the average, in terms of the expected value of net dollar benefits, although it may be rational in terms of expected utility.

Column 6 assumes that the decision not to insure is made independently of the sprinkler decision, and, hence, attributes no insurance savings to sprinklers. Net losses result. In both cases, the full estimated value of losses averted (not just uninsured losses) is credited to sprinklers.

By comparing column 6 of table 19 with the base-case results of table 17 , it may be seen that net losses are estimated to be greater for the sprinkler used in the uninsured house than in the insured house unless the savings from not insuring are tied to the sprinkler investment. This reflects the allowance of significant discounts in insurance premiums under the base case. If there were no premium discounts for the insured house, the sprinkler system would be more cost effective in the uninsured house than in the insured house, as one might expect. A corollary of this result is that fire insurance makes less economic sense for a sprinklered house than for an unsprinklered house, unless 
the risk reduction from sprinklers is reflected in insurance premium discounts.

Column 7 of table 19 shows net benefits for sprinklers evaluated under Condition I, that is, without the presence of a smoke detector. The net losses are lower than under the base case (Condition II with smoke detectors), because of the larger impact of sprinklers in reducing risk of loss. However, this case is for the most part unrealistic because sprinklers generally would be used in conjunction with smoke detectors. It is highly unlikely that a home protection system would include sprinklers and not the much lower priced smoke detector. The case of sprinklers used alone is included in order to suggest the added benefits that may accrue to a sprinkler system when the benefits of smoke detectors may not be attainable, such as when occupants are incapacitated and cannot response to a smoke detector. Of course, in such a situation the occupants' risk exposure would likely be higher than the average risk data used in the case studies, and therefore the case studies results are tentative.

Column 8 of table 19 shows net benefits for sprinklers evaluated for a rental house. The sprinkler system is estimated to be somewhat more cost effective for the owner of a rental house than for the owner/occupant, other things being equal, although net losses of about $\$ 800$ are estimated for this case illustration. Larger tax deductions of system expenses, such as for depreciation and operating, maintenance and repair costs, account for the better showing of the rental house. These results are, however, also contingent on the assumption that the landlord will receive a rent premium 
fully reflective of the tenant's reduced risk of fire loss, in addition to the owner's direct benefits of increased protection on the structure.

Table 20 shows the results of a break-even analysis based on Case II assumptions, i.e., a waiver of property taxes and a pass-through to the homeowner of the estimated value of municipal cost avoidance. It shows that, other factors remaining the same, estimated net losses for this case illustration could be eliminated by adding any one of the following changes to the Case II assumptions; (1) a risk of fire one and a half times as high as the U.S. average rate; (2) a value of life of roughly $\$ 850,000$ using discounted values, or as low as about $\$ 400,000$ using non-discounted values; (3) a 16 percent discount in homeowner's insurance rates; or (4) a passthrough of reductions in builder's costs of about $\$ 98$. 
Table 20. Case II: Break-Even Values

(Note: Assumptions Are Initialized to Case II Assumptions After Each BreakEven Calculation)

\begin{tabular}{|c|c|c|}
\hline Parameter & $\begin{array}{l}\text { Break-Even } \\
\text { Value }\end{array}$ & $\begin{array}{l}\text { Case II } \\
\text { Value }\end{array}$ \\
\hline $\begin{array}{l}\text { Purchase and Installation Cost } \\
\text { (after taxes and financing) }\end{array}$ & $\$ 1,347$ & $\$ 1,445$ \\
\hline Probability of Fire & .012 & .00856 \\
\hline $\begin{array}{l}\text { Value of a Life Saved } \\
\text { (Discounted) }\end{array}$ & $\$ 839,000$ & $\$ 500,000$ \\
\hline $\begin{array}{l}\text { Value of a Life Saved Plus } 3.56 \\
\text { Injuries Averted }{ }^{a} \text { (Not Discounted) }\end{array}$ & 429,000 & -- \\
\hline $\begin{array}{l}\text { Average Value Uninsured Property } \\
\text { T. = Per Fire Without Sprinklers }\end{array}$ & $\$ 1,800$ & $\$ 525$ \\
\hline $\begin{array}{l}\text { Percentage Discount in Homeowner's } \\
\text { Insurance Rate }\end{array}$ & $16 \%$ & $13 \%$ \\
\hline $\begin{array}{l}\text { Homeowner's Insurance Premium Per } \\
\quad \$ 1,000 \text { of Coverage }\end{array}$ & $\$ 3.74$ & $\$ 2.96$ \\
\hline $\begin{array}{l}\text { Annual Property Tax Reduction Reflective } \\
\left.\text { of Municipal Cost Savings (Constant } \$^{\prime} s\right)^{b}\end{array}$ & $\$ 7.11$ & $\begin{array}{l}\$ 85.16 \text { Reduction } \\
\text { (Waiver of pro- } \\
\text { perty tax on } \\
\text { the system) }\end{array}$ \\
\hline $\begin{array}{l}\text { Reduction in Builder's Costs (assuming } \\
\text { a full pass-through to home buyers) }\end{array}$ & $\$ 98$ & 0 \\
\hline $\begin{array}{l}\text { Federal Income Tax Credit } \\
\text { (as a \% of Initial Purchase and } \\
\text { Installation Cost) }\end{array}$ & $6 \%$ & 0 \\
\hline
\end{tabular}

aperived according to Approach 2 described in section 3.2.1.

${ }^{b}$ Tax reductions in addition to a waiver of property tax on the capitalized value of the sprinkler system. The break-even solution indicates that an additional reduction of $\$ 7.11$ annually is required to bring net losses to zero, i.e., a total reduction of $\$ 92.27$. 


\section{SUMMARY AND CONCLUSIONS}

This paper has developed a model for evaluating the expected value of net benefits to the homeowner of a fire sprinkler system, and has illustrated the model in a series of hypothetical case studies for new, single-family dwellings in the U.S. The resuits of the case studies are based on many assumptions, and actual net benefits from a sprinkler system may be considerably different from those estimated here. The cases may provide insight as to how the cost effectiveness of these systems is affected by particular conditions.

Some inferences that may be drawn from the hypothetical case studies are the following: (1) The cost effectiveness of residential sprinkler systems is improved by code changes which allow the use of approved plastic pipe; (2) sprinkler systems may be uneconomical under low-to-average conditions of risk for the homeowners who independently purchases a system; but they may be cost effective under conditions of high risk; (3) sprinkler systems are more likely to be cost effective, other factors being the same, for homeowners who are part of a community of sprinkler users and who receive the benefit of attributed cost avoidance by local government or by the home builder; (4) homeowners who live in localities with "water standby fees" or who use commercial sprinkler systems are unlikely to have a cost-effective sprinkler systems under average probabilities of fire and related death, injury, and property loss; (5) sprinkler systems are more likely to be cost effective when used in situations where additional protection is needed, such as situations where the benefits of smoke detectors alone may not be attainable, for example, when occupants are incapacitated and cannot respond to the alarm. 
These findings, though based on hypothetical cases, are helpful in identifying the following critical areas for further exploration: (1) the potential of municipal cost savings from sprinklered houses and the feasibility of corresponding tax reductions, (2) the feasibility of cost/performance tradeoffs between sprinklers and fire resistant construction methods and materials, (3) the availability of discounts on insurance premiums, (4) the practice of levying water demand charges for sprinklered houses, (5) approaches to lowering the cost of sprinklers, (6) retrofit capability, (7) partial systems for fatality-prone areas of the house, and (8) benefits accruing to households with different behavioral and demographic characteristics and living in houses of different construction and age.

Studies of municipality experience with mandated sprinkler systems would be useful in estimating municipal cost avoidance. An investigation of the technical substitutability of different building approaches to residential fire safety should contribute to the estimation of construction cost tradeoffs. Further testing and validation of the impact of sprinklers on fire losses might facilitate appropriate changes in insurance rate structures. The issue of water demand charges will require cooperation between local water utilities and local governments who wish to encourage the widespread use of residential sprinklers.

The model in its present form is not appropriate as a decision tool for the homeowner. Incorporation of utility analysis is one requirement for such an extension. The models of bullder/developers and for municipal government 
decisions (as given in the appendix) also require further refinement to make them convenient for use by builders, developers, and municipalities. Research efforts are needed to address issues related to the computation of expected values and expected utilities of fire mitigation strategies for use in the various decision models. These issues include the appropriate methodology for assigning monetary values to future lives saved, to injuries of different degrees of seriousness, and to unique properties, as well as the appropriate procedures to follow in regard to discounting lives saved and injuries averted in the various decision models. Data is needed to support applications of the models to a variety of real-1ife situations. 
Ad Hoc Insurance Committee on Residential Sprinklers, Report on 1980 Property Loss Comparison Fires. Reprinted by Federal Emergency Management Agency, U.S. Fire Administration; National Fire Data Center, Washington, D.C.) November $1980,22$.

Aklbrandt, Roger, "Efficient Output of a Quasi-Public Good-Fire Services," Ph.D. Dissertation, Department of Economics, University of Washington, 1972.

Arrow, K. J., Social Choice and Individual Values, Second Edition (New Haven, Connecticut: Yale University Press, 1963).

Battelle Columbus Laboratories, Development of an Experimental Prototype LowCost Electronic Sensor/Actuator for a Residential Automatic Sprinkler Head,

(prepared for the Federal Emergency Management Agency), undated.

Budnick, Edward K., Estimating Effectiveness of State-of-the-Art Detectors and Automatic Sprinklers on Life Safety in Residential Occupancies, National Bureau of Standards, NBSIR 84-2819, January 1984.

Calabresi, Guido, The Costs of Accidents: A Legal and Economic Analysis. (New Haven, Connecticut: Yale University Press; 1970).

Carlin, John J. III; Stephens, Allen, "New Residential Sprinkler Standards Adopted," The International Fire Chief; February 1981, 23.

Chapman, Robert E.; Chen, Phillip T.; Hall, William G., Economic Aspects of Fire Safety in Health Care Facilities: Guidelines for Cost-Effective Retrofits, National Bureau of Standards, NBSIR 79-1902, November 1979..

Clark, Louis P., A Life-Cycle Cost Analysis Methodology for Fire Protection Systems in New Health Care Facilities, National Bureau of Standards, NBSIR 82-2558, July 1982.

"Cost-Effective Sprinkler Protection of Fast-Food Restaurants," Fire Journal, November $1979,3-8$.

Dacy, Douglas C. and Kunreuther, Howard, The Economics of Natural Disasters (New York: The Free Press; 1969).

"Dousing Home Fires," The Washington Post; Saturday, July 10, 1982 , E-1.

Federal Emergency Management Agency, Bulletin FA 43 (Revised), January 1982.

Federal Emergency Management Agency, Report to Congress on Fire Sprinkler Protection Systems: Detectors, Remote Alarms Systems and Sprinklers, U.S. Government Printing Office, Washington, D.C., June 1981, 54.

Ferri, Michael G., "An Application of Hedonic Indexing Methods to Monthly Changes in Housing Prices, 1965-1975," AREUER Journal, Vo1. 5, 1977, 455-465.

Fire in the United States, Fourth Edition, Federal Emergency Management Agency, September 1982, Washington, D.C. 
Foehl, John M., "In Quest of an Economical, Automatic Fire Suppression System for Single-Family Residences," Fire Journal, Vol. 69, No. 5, September 1974.

Gomberg, Alan; Buchbinder, Benjamin; Offensend, Fred, J., Evaluating Alternative Strategies for Reducing Residential Fire Loss - The Fire Loss Mode1, National Bureau of Standards, NBSIR 82-2551, Washington, D.C. 20234, August 1982.

Gomberg, Alan; Hall, John R., Jr.; Stiefel, S. Wayne; Offensend, Fred, J.; Pacey, Ann J., A Decision Model for Evaluating Residential Fire-Risk Reduction Alternatives, National Bureau of Standards, NBSIR, in preparation 1984.

Graham, J. D. and Vaupel, J. W., "Value of a Life: What Difference Does It Make?." Risk Analysis. Vol. 1, No. 1; March 1981, 89.

Grinnel Fire Protection Systems, Co., Inc., Bulletin No. 130 (Revised), 10 Dorrance Street, Providence, Rhode Island 02903, March 1982.

Hausman, Jerry A., "Individual Discount Rates and the Purchase and Utilization of Energy-Using Durables." Bell Journal of Economics. Vol. 10, No. 1; 1979.

Holland, Daniel M. and Meyers, Steward C., Trends in Corporate Profitability and Capital Costs, WP 937-77, Alfred P. Sloan School of Management (Cambridge, MA: Massachusetts Institute of Technology; 1977).

Interview with Brand Laseter, Trojan Plastics, Inc., Tampa, Florida, October 27,1982 .

Interview with Dom Yezzi, Insurance Services Office, 160 Water Street, New York; 1982 December 20.

Interview with Kathy Vernot, Director, Life-Safety Division, Central Sprinkler Corporation, 1981 November.

Interview with Keith Swinehart, Vanguard Plastics, Inc., McPherson, Kansas, October 27,1982 .

Interview with Melville Mossmar, Editor of Mechanical Systems Section of MEANS Building Systems Cost Guide 1982, October 20, 1982.

Jackson, Ralph J., "Insurance Incentives for Residential Sprinklers," International Fire Chief, Vol. 47, No. 7, July 1981, 11 .

Jones-Lees, M. W., The Value of Life: An Economic Analysis (Chicago, IL: University of Chicago Press, 1976).

Marsha11, Harold E. and Ruegg, Rosalie T., Simplied Energy Design Economics, National Bureau of Standards, NBS Special Publication 544, 1980.

Maybee, Walter W., "A Brief History of Fire Protection in the U.S. Atomic Energy Commission 1947-1975," A paper presented at the National Fire Protection Association Fall Conference, 1978. 
McGraw-Hill Information Systems, 1982 Dodge Manual for Building Construction Pricing and Scheduling, Annual Edition No. 17, New York, New York, 1981.

McGraw-Hill Information Systems, Dodge Building Cost Calculator and Valuation Guide, Edition 41, New York, New York, January/March 1981.

McConnaughey, John S. Jr., An Economic Analysis of Building Code Impacts: A Suggested Approach, NBSIR 78-1528, October 1978, 30-31.

Mishan, E. J., Cost-Benefit Analysis (New York: Praeger; 1976).

Mishan, E. J., "Evaluation of Life and Limb: A Theoretical Approach," Journal of Political Economy, July-August 1971 , 687-705.

Munson, Michael J. and Ohls, James C., Indirect Costs of Residential Fires, Federal Emergency Management Agency, FA-6; April 1980, (U.S. Government Printing Office: 1980, 0-319-251/6207).

National Fire Protection Association, Inc., "Sprinkler Systems--One- and TwoFamily Dwellings, 1980," ANSI/NFPA 13D, November 20, 1980.

"New Residential Sprinkler Standards Adopted." The International Fire Chief; February $1981,23$.

"Preliminary Data-Rural/Metro Fire Sprinkler Tests," A pamphlet provided by the Rural/Metro Fire Department, Inc., of Scottsdale, Arizona.

Reiger, Arthur J., Marketplace Realities and Solar Economics, U.S. Department of Housing and Urban Development Report, distributed by the National Solar Heating and Cooling Information Center, June 1978.

Reilly, Edward J., "Residential Sprinkler Systems--Where Do We Go From Here?," A paper presented at the Fourth Annual Conference on Low Cost Residential

Sprinkler Systems, sponsored by the U.S. Fire Administration; September 25-26, $1979,3$.

Rolf Jensen and Associates, Inc., Study to Establish the Existing Automatic Fire Suppression Technology for Use in Residential Occupancies, A report prepared for the U.S. Department of Commerce, National Fire Provention and Central Administration, Washington, D.C., August 1977.

R.S. Means Co., Inc., Building Construction Cost Data: 1978: Duxburg, MA. R.S. Means Co., Inc., Building Construction Cost Data: 1982, Duxburg, MA. R.S. Means Co., Inc., MEANS Building Systems Cost Guide: 1982, Duxburg, MA. R.S. Means Co., Inc., Square Foot Costs: 1982, Duxburg, MA.

Ruegg, Rosalie T., Evaluating Incentives for Solar Heating, National Bureau of Standards, NBSIR 76-1127, September 1976. 
Ruegg, Rosalie T., et. al., Economic Evaluation of Solar Energy Systems in Commercial Buildings; Methodology and Case Studies, National Bureau of

Standards, NBSIR 82-2540, July 1982, 87-89.

Ruegg, Rosalie T., Life-Cycle Cost Manual for the Federal Energy Management Program, National Bureau of Standards, Handbook 135 (Revised) May 1982.

Ruegg, Rosalie T. and Marshall, Harold E., "Economics of Building Design," Solar Age, July 1981, 22-27.

Ruegg, Rosalie T., Marshall Harold E., Driscoll, Porter. "Life-Cycle Costing," Architectural Graphics Standards, 7th Edition, February 1981.

Ruegg, Rosalie T., Petersen, Stephen R., Marshall, Harold E., Recommended Practice for Measuring Life-Cycle Costs of Buildings and Building Systems, National Bureau of Standards, NBSIR 80-2040, June 1980.

"San Clemente Protects New Residences With Automatic Sprinklers," Fire Chief Magazine; August 1981, 100 .

She11 Chemical Company, Performance Report, SC:550-81; September 1981.

Society of Fire Protection Engineers, SFPE Bulletin; December 1980.

Stevenson, Gelvin, Fire Insurance: Its Nature and Dynamics, A report prepared at Princeton University for the U.S. Department of Commerce, National Fire Prevention and Control Administration); October 1978, 75-77.

The Rand Corporation, Fire Department Deployment Analysis: A Public Policy Analysis Case Study, Ed. W. E. Walker, J. M. Chaiken, and E. J. Ignall (New York: North Holland, 1979).

U.S. Bureau of the Census, Statistical Abstract of the United States 1980 , Washington, D.C.

U.S. Bureau of the Census, Statistical Abstract of the United States 1981, Washington, D.C.

U.S. Department of Commerce, Bureau of Industrial Economics, Construction Review, Vo1. 28, No. 3, May/June 1983.

U.S. Fire Administration (USFA), Federal Emergency Management Agency (FEMA) (J.W. Overbey, personal interview with Al Gomberg, August 1982).

U.S. House of Representatives, Subcommittee on Science, Research and Technology, Prepared testimony of Joseph A. Moreland, Acting Administrator USFA/FEMA, before the Subcommittee, February 25, 1981.

Viniello, John A., "An 0ld Idea With a New Technology," Grinnell Fire Protection Systems Company, Inc. (undated). 
Weber, S. F., Thompson, B. E., and Lippiatt, B. C., Economic Framework for Cost-Effective Residential Water Conservation Decisions, National Bureau of Standards, NBSIR 81-2304, August 1981 .

Zeckhauser, Richard, "Procedures for Valuing Lives," Public Policy. Vol. No. 4, Fal1 1975, 419-464. 
Appendix. Related Decision Models for the Builder/Developer and the Municipal Government

\section{A. 1 Decision Model for the Builder/Developer}

Because the majority of houses being constructed today is on a speculative "for sale" basis, the builder/developer is a key decisionmaker regarding the characteristics and features of new housing. A builder/developer of new housing may assess the market demand for houses equipped with sprinkler systems and install them as a standard feature or offer them as an option to potential buyers. Emphasis in marketing might be on safety and/or costeffectiveness.

In offering sprinklers as a standard feature, the builder/developer weighs the costs of purchasing and installing the systems against the ability to sell the houses at an effectively higher selling price, and against any offsetting cost reductions that may be realized by including sprinklers in the housing . Offsetting cost reductions may include lower land costs due to higher density of buildings, lower construction costs due to reduced requirements for fire resistant materials, and reduced land set-aside for fire lanes and fire stations. The ability of a builder/developer to charge a higher price for speculative houses equipped with fire sprinklers depends on consumer acceptance and perceived value.

Based on patterns observed in the market acceptance of other new technologies for the home, developers of higher-priced housing, for which the sprinklers would add a smaller percentage increase to first costs and to mortgage 
payments, could be expected to be more successful in covering their costs.1 By making the systems standard, the builder/developer of a sizable number of houses might be able to install the systems at a lower cost than could a custom builder, through, for example, quantity discounts on materials, increased labor efficiencies, and smaller markups for overhead and profit. The large-scale builder/developer is more likely to attain the cost offsets mentioned earlier, such as reduced expenditures for fire resistant construction, than the small-scale custom builder because of the critical minimum level of community participation required to justify these kinds of cost reductions.

In offering sprinklers as an option, rather than as a standard feature, the builder/developer avoids the risks of an uncertain market. However, by making the systems optional, builders/developers may not attain any economies of scale in their provision. More importantly, the level of community participation may be inadequate to justify the allowance by public officials of offsetting cost reductions in land and construction.

The following three investment cases can be identified for the speculative builder/developer:

Case I. The builder/developer voluntarily installs sprinkler systems as a standard feature in a subdivision or community of speculative "for sale" houses.

\footnotetext{
$1_{\text {Reiger, Marketplace Realities and Solar Economics. }}$
} 
Case II. The builder/developer voluntarily offers the system as an option to homebuyers who request it.

Case III. The builder/developer installs the systems in all houses built in compliance with a mandatory requirement set by public officials.

In each of these cases, all of the relevant decision variables to the builder/developer involve more-or-less up-front cash amounts that require no time adjustments for estimating the economic efficiency of the investment. Furthermore, Case II, whereby the builder/developer installs a sprinkler system only at the request of the homebuyer, can likely be dismissed as not requiring analysis. This is because the builder/developer may be assumed to shift the full cost of the system to the homebuyer, and, thereby, avoid the risk of an uncertain selling price. And, because of a probable lack of full community participation in electing the sprinkler option, the builder/ developer would likely receive little in the way of offsetting cost concessions from the local government.

Cases I and III are similar in that they both involve total participation of new houses in the use of sprinklers and therefore might involve cost concessions to the builder/developer. They may differ, however, in the ability of the builder/developer to recoup the purchase and installation costs of the systems. In Case I, where sprinkler systems are voluntarily installed as a standard feature, the builder/developer accepts fully the vagaries of market demand for the systems and may or may not be able to pass on the costs to homebuyers. In Case III, where all new housing in a community is required by law to have sprinkler systems, builders/developers of new, sprinklered housing do not face competition within the community from new, non-sprinklered 
housing. They, therefore, are more likely to be able to pass along fully to the homebuyer the cost of the sprinkler system, other things being equal.

The following net benefits model evaluates the economic efficiency to the builder/developer of either of these cases:

$$
\mathrm{NB}_{\mathrm{B} / \mathrm{D}}=\mathrm{LCR}_{\mathrm{O}}+\mathrm{CCR}_{\mathrm{O}}-\mathrm{TPI}_{\mathrm{B} / \mathrm{D}}+\mathrm{RS}_{\mathrm{O}}+\mathrm{OGI} \text {, }
$$

where,

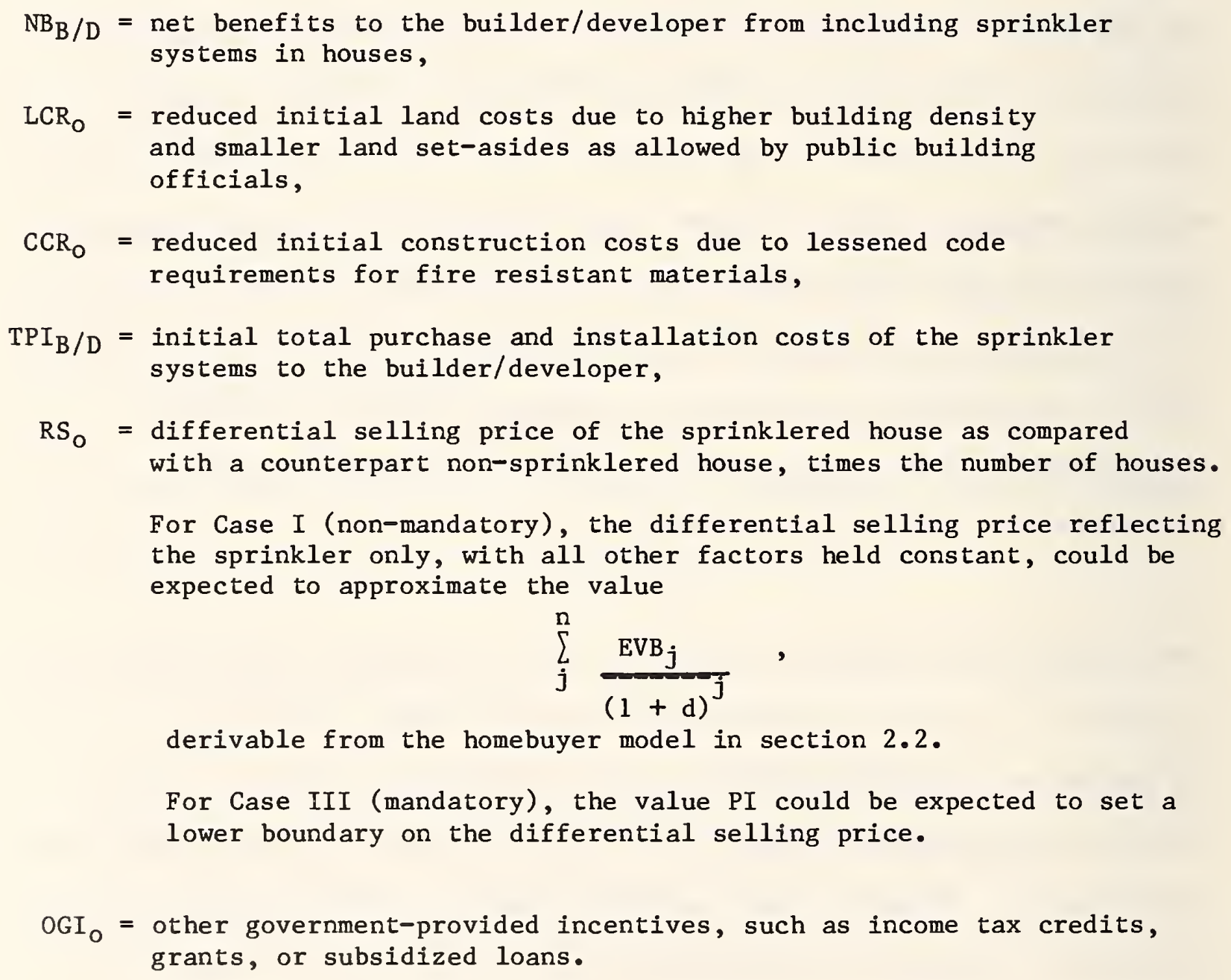




\section{A.2 Decision Model for the Municipal Government}

While public officials do not directly purchase and install residential sprinkler systems, they can make decisions which critically affect the investment decisions of those who do. Public officials may weigh the costs to new and existing communities of meeting increased needs for fire loss abatement through the use of conventional fire protection strategies, and may determine that installing sprinkler systems in houses is the least-cost alternative to the community. They may then influence the investment decisions of builders/developers regarding sprinklers through legislative mandates or through the provision of incentives such as those cost reduction provisions mentioned above, or through both. They may influence homeowner investment decisions by effectively reducing system costs, through, for example, waiver of property tax on the capitalized value of the systems, pass-throughs of municipal cost savings, tax credits, and depreciation

\section{allowances.}

Three economic questions at the community decision level are: (1) Is it economically efficient to the community at large to mandate or encourage the use of residential fire sprinklers? (2) What level of cost concessions to builders/developers can be justified on economic grounds to encourage their installation of sprinkler systems? (3) What will be the likely effects on local governmental costs?

The life-cycle cost model developed in this section on an exploratory basis is intended to address the first question and to determine upper boundary estimates for the second and third questions. 
The municipal decision model below encompasses the total of individual households in the comminity, all under average conditions. It takes into account the cost of firefighter deaths and injuries, fire department costs, differential housing construction costs, and differential community infrastructure costs, in addition to the total of uninsured direct and indirect homeowner fire losses, total insurance costs, and aggregate sprinkler system $\cos t s .1$

Find the least-cost alternative, $\mathrm{LCC}_{\mathrm{C}}$ or $\mathrm{LCC}_{\mathrm{s}}$ :

$$
\begin{aligned}
& \mathrm{LCC}_{\mathrm{c}}=\mathrm{H} \cdot\left\{\left[\mathrm{PLV}_{\mathrm{c}}(\mathrm{f})+\mathrm{DLV}_{\mathrm{c}}(\mathrm{f})+\mathrm{ILV}_{\mathrm{c}}(\mathrm{f})+\mathrm{FFLV}_{\mathrm{C}}(\mathrm{f})+\mathrm{IV}_{\mathrm{c}}(\mathrm{f})\right] \cdot \mathrm{P}(\mathrm{F})+\mathrm{IP}_{\mathrm{ns}} \cdot(\mathrm{BV}+\mathrm{CV})\right] \text {. } \\
& \left.\underset{n, d, e}{\mathrm{UPW}^{*}}+\mathrm{FDC}_{\mathrm{c}}+\mathrm{FCC}_{\mathrm{C}}+\mathrm{OCC}_{\mathrm{c}}\right\} \\
& \mathrm{LCC}_{S}=H \cdot\left\{\left[\left[\operatorname{PLV}_{S}(f)+\mathrm{DLV}_{S}(f)+\mathrm{ILV}_{\mathrm{S}}(\mathrm{f})+\mathrm{FFLV}_{\mathrm{S}}\left(\mathrm{f}+\mathrm{IV}_{\mathrm{S}}(\mathrm{f})\right] \cdot \mathrm{P}(\mathrm{F})+\mathrm{IP} \mathrm{P}_{\mathrm{S}} \cdot(\mathrm{BV}+\mathrm{CV})\right]\right.\right. \text {. } \\
& \left.\underset{\mathrm{n}, \mathrm{d}, \mathrm{e}}{\mathrm{UPW}^{*}}+\overline{\mathrm{PI}}+\overline{\mathrm{OP}}+\overline{\mathrm{M}}+\overline{\mathrm{OC}}+\mathrm{FDC}_{\mathrm{s}}+\mathrm{FCC}_{\mathrm{s}}+\mathrm{OCC}_{\mathrm{s}}\right\}
\end{aligned}
$$

where,

$$
\begin{aligned}
\mathrm{LCC}_{\mathrm{C}}= & \text { total life-cycle cost of the conventional approach to } \\
& \text { comminity fire protection, } \\
\mathrm{LCC}_{\mathrm{S}=} & \text { total life-cycle cost of a new approach to community fire } \\
& \text { protection which relies primarily on self-protection } \\
& \text { through the use of sprinkler systems, } \\
\mathrm{H}= & \text { the number of houses affected, }
\end{aligned}
$$

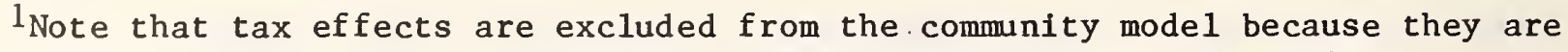
assumed to be transfers that do not affect overall costs. Note also

that resale value is excluded from the comminity model because the useful

life of the system, rather than the investor's holding period, is assumed to be used for the study period.
} 
PLV (f) = the average annual dollar value of uninsured and non-reimbursed property loss if a fire occurs, where subscript $c$ indicates the absence of sprinkler systems, and a given level of community fire protection services as reflected by the values of $\mathrm{FDC}_{\mathrm{C}}$, $\mathrm{FCC}_{C}$, and $\mathrm{OCC}_{\mathrm{C}}$, and subscript $\mathrm{s}$ indicates the presence of sprinkler systems in combination with a given level of community fire protection services as reflected by the values $\mathrm{FDC}_{S}, \mathrm{FCC}_{\mathrm{S}}$, and $\mathrm{OCCs}$,

$\operatorname{DLV}(\mathrm{f})=$ the average annual number of occupant deaths if a fire occurs times an estimated dollar value per death, where subscript $c$ indicates the absence of sprinkler systems, and a given level of comminity fire protection services as reflected by the values of $\mathrm{FDC}_{\mathrm{c}}, \mathrm{FCC}_{\mathrm{c}}$, and $\mathrm{OCC}_{\mathrm{c}}$, and subscript $\mathrm{s}$ indicates the presence of sprinkler systems in combination with a given level of community fire protection services as reflected by the values of $\mathrm{FDC}_{\mathrm{S}}, \mathrm{FCC}_{\mathrm{S}}$, and $\mathrm{OCC}_{\mathrm{S}}$,

ILV $(f)=$ the average annual number of civilian injuries if a fire occurs times an estimated dollar value per injury, where subscript $c$ indicates the absence of sprinkler systems, and a given level of community fire protection services as reflected by the values of $\mathrm{FDC}_{\mathrm{c}}, \mathrm{FCC}_{\mathrm{C}}$, and $\mathrm{OCC}_{\mathrm{c}}$, and subscript $\mathrm{s}$ indicates the presence of sprinkler systems in combination with a given level of community fire protection services as reflected by the values of $\mathrm{FDC}_{\mathrm{S}}, \mathrm{FCC}_{\mathrm{S}}$, and $\mathrm{OCC}_{\mathrm{S}}$,

FFLV (f) = the average annual number of firefighter injuries if a fire occurs times an estimated dollar value per injury, where subscript $c$ indicates the absence of sprinkler systems, and a given level of community fire protection services as reflected by the values of $\mathrm{FDC}_{\mathrm{C}}, \mathrm{FCC}_{\mathrm{C}}$, and $\mathrm{OCC}_{\mathrm{C}}$, and subscript $\mathrm{s}$ indicates the presence of sprinkler systems in combination with a given level of community fire protection services as reflected by the values of $\mathrm{FDC}_{\mathrm{S}}, \mathrm{FCC}_{\mathrm{S}}$, and $\mathrm{OCC}_{\mathrm{S}}$,

IV $(f)=$ the average annual dollar value of out-of-pocket indirect costs if a fire occurs, where subscript $c$ indicates the absence of sprinkler systems, and a given level of community fire protection services as reflected by the values of $\mathrm{FDC}_{\mathrm{C}}, \mathrm{FCC}_{\mathrm{C}}$, and $\mathrm{OCC}_{\mathrm{c}}$, and subscript $\mathrm{s}$ indicates the presence of sprinkler systems in combination with a given level of community fire protection services as reflected by the values of $\mathrm{FDC}_{\mathrm{S}}, \mathrm{FCC}_{\mathrm{S}}$, and $\mathrm{OCC}_{\mathrm{S}}$,

$P(F)=$ probability of fire in a year

IP = annual insurance premium rate, where subscript ns indicates no sprinkler and $s$ indicates sprinklers installed, 


$$
\begin{aligned}
\mathrm{BV}= & \text { average value of the structure to be insured, } \\
\mathrm{CV}= & \text { average value of the contents to be insured, } \\
\mathrm{FDC}= & \text { the life-cycle cost per house of providing, operating and } \\
& \text { maintaining a fire station, and subscripts c and } \mathrm{s} \text { indicate two } \\
& \text { levels of protection as measured by average response time, } \\
& \text { level c being shorter time than } \mathrm{s}, \\
\mathrm{FCC}= & \text { the average initial cost per house of using fire resistant } \\
& \text { materials, where subscripts c and } \mathrm{s} \text { indicate two levels of fire } \\
& \text { resistance, level c being a greater level of resistance than s, } \\
\mathrm{OCC}= & \text { other costs to the community per house associated with } \\
& \text { collectively provided fire protection, such as fire lanes, } \\
& \text { where subscripts } \mathrm{c} \text { and } \mathrm{s} \text { indicate two levels of protection, } \\
& \mathrm{c} \text { indicating a greater level of protection than s, and } \\
\mathrm{n}= & \text { the average economic life of residential sprinkler systems } \\
& \text { which is assumed to be identical to its average useful life. } \\
\overline{\mathrm{PI}}, \overline{\mathrm{OP},} \overline{\mathrm{M}}, & \overline{\mathrm{OC}} \text { are as defined previously for the homeowner model. }
\end{aligned}
$$

The alternative which minimizes total life-cycle costs will be the economically efficient approach for the community, other things being equal. If $\mathrm{LCC}_{C}$ is greater than $\mathrm{LCC}_{S}$, the amount by which the former exceeds the latter provides a rough estimate of the maximum amount which the community should be willing to spend to encourage (or require) the switch from "Alternative c" to "Alternative s".

Note in interpreting the model that it is assumed that the homeowner evaluates the cost-effectiveness of a personal investment in sprinklers in light of a fixed level of community fire-protection service, while the local government evaluates the decision in light of a variable level of community fire protection service.

1OCC encompasses, in principle, effects associated with variable housing densities; however, quantification of density benefit-cost effects is very difficult in practice. 
Hence, in the case of the homeowner, if $\operatorname{PLV}(f)$ is the expected value of uninsured property loss without a sprinkler system, then $\ell(s, f) \cdot \operatorname{PLV}(f)$ is the reduction in that loss attributable to a sprinkler system, where $\ell(s, f)=$ the percentage reduction by sprinklers. In the case of the municipal government, however, the value of fire property loss (PLV) may vary as the values of FDC, FCC, and OCC are changed.

Note also that the above model is expandable to a more general cost minimization model covering many alternative combinations of sprinkler use and collective fire protection, rather than just two alternatives as modeled here.

The direct costs to the community of purchasing, installing, operating, and maintaining a "saturation level" of sprinkler systems, i.e., $\mathrm{H}[\overline{\mathrm{PI}}+\overline{\mathrm{OP}}+\overline{\mathrm{M}}+$ $\overline{\mathrm{OC}}]$ can be used in a break-even context to determine the aggregate value of increased benefits and cost reductions that must be achieved to make it cost effective for the community to provide a given level of fire safety through the use of sprinklers. That is, at the break-even point, $\mathrm{H} \cdot\left[\overline{\mathrm{PI}}+\overline{\mathrm{OP}}+\overline{\mathrm{M}}+\overline{\mathrm{OC}}=\mathrm{H} \cdot\left\{\left[\left[\mathrm{PLV}_{\mathrm{C}}(\mathrm{f})-\mathrm{PLV}_{\mathrm{S}}(\mathrm{f})+\mathrm{DLV}_{\mathrm{C}}(\mathrm{f})-\mathrm{DLV}_{\mathrm{S}}(\mathrm{f})\right)+\left(\operatorname{ILV}_{\mathrm{C}}(\mathrm{f})\right.\right.\right.\right.$ $\left.\left.-\operatorname{ILV}_{s}(f)\right)+\left(F_{F L V}(f)-F F L V_{s}(f)\right)+I V_{c}(f)-I V_{s}(f)\right] \cdot P(F)+\left[\left(I P_{n s}-I P_{s}\right) \cdot\right.$ $\left.(B V+C V)]] \cdot U P W *_{n}, d, e+\left(F D C_{c}-F D C C_{s}\right)+\left(F C C C_{C}-F C C C_{s}\right)+\left(O_{C C C}-O C C_{s}\right)\right\}$ 

NBS-114A (REV. 2-8C)

U.S. DEPT. OF COMM.

BIBLIOGRAPHIC DATA

SHEET (See in struction s) 1. PUBLICATION OR
REPORT NO. NBS / TN-1203

4. TITLE AND SUBTITLE

A Benefit-Cost Mode1 of Residential Fire Sprinkler Systems

\section{5. $A U T H O R(S)$}

Rosalie T. Ruegg and Sieglinde K. Fuller

6. PERFORMING ORGANIZATION (If joint or other than NBS, see instructions)

NATIONAL BUREAU OF STANDARDS

DEPARTMENT OF COMMERCE

GAITHERSBURG, MD 20899

7. ContracUGrant No.

8. Type of Report \& Period Covered

Final

9. SPONSORING ORGANIZATION NAME AND COMPLETE ADDRESS (Street, City, State, ZIP)

Fire Safety Technology Division

Center for Fire Research

Nationa1 Engineering Laboratory

National Bureau of Standards

Gaithersburg, MD 20899

10. SUPPLEMENTARY NOTES

Document describes a computer program; SF-185, FIPS Software Summary, is attached.

11. ABSTRACT (A 200-word or less factual summary of most significant information. If document includes a significant bibliography or literoture survey. mention it here)

This paper develops and applies decision models for evaluating the economic efficiency of providing fire loss mitigation in houses through the use of a new technology: fast-response sprinkler systems. A model is developed for calculating present value net benefits as they would accrue to an owner-occupant or an owner of a rental house who installs a sprinkler system. Costs and benefits of owning a system are estimated for selected hypothetical cases pertaining to a new, singlefamily dwelling in the United States. The estimates are then used to illustrate the model. Minimum or maximum values that key decision variables must take in order for sprinkler systems to be cost effective in the selected applications are calculated through break-even analysis. Related models are developed for evaluating the economic merits of sprinkler systems from the standpoint of developers and local governments. Implications for the research and building communities are discussed.

12. KEY WORDS (Six to twelve entries; alphabetical order; capitalize only proper names; and separate key words by semicolons) building economics; economic analysis; fire protection; 1ife-cycle costing; net benefit analysis; residential fire safety; risk-benefit analysis; sprinkler systems.

\section{AVAILABILITY}

[X] Unlimited

For Official Distribution. Do Not Release to NTIS

[X] Order From Superintendent of Documents, U.S. Government Printing Office, Washington, D.C. 20402.

[ Order From National Technical Information Service (NTIS), Springfield, VA. 2216I
14. NO. OF PRINTED PAGES

$$
149
$$

15. Price 



\section{Technical Publications}

\section{Periodicals}

Journal of Research-The Journal of Research of the National Bureau of Standards reports NBS research and development in those disciplines of the physical and engineering sciences in which the Bureau is active. These include physics, chemistry, engineering, mathematics, and computer sciences. Papers cover a broad range of subjects, with major emphasis on measurement methodology and the basic technology underlying standardization. Also included from time to time are survey articles on topics closely related to the Bureau's technical and scientific programs. As a special service to subscribers each issue contains complete citations to all recent Bureau publications in both NBS and non-NBS media. Issued six times a year.

\section{Nonperiodicals}

Monographs-Major contributions to the technical literature on various subjects related to the Bureau's scientific and technical activities.

Handbooks-Recommended codes of engineering and industrial practice (including safety codes) developed in cooperation with interested industries, professional organizations, and regulatory bodies.

Special Publications-Include proceedings of conferences sponsored by NBS, NBS annual reports, and other special publications appropriate to this grouping such as wall charts, pocket cards, and bibliographies.

Applied Mathematics Series-Mathematical tables, manuals, and studies of special interest to physicists, engineers, chemists, biologists, mathematicians, computer programmers, and others engaged in scientific and technical work.

National Standard Reference Data Series-Provides quantitative data on the physical and chemical properties of materials, compiled from the world's literature and critically evaluated. Developed under a worldwide program coordinated by NBS under the authority of the National Standard Data Act (Public Law 90-396).

NOTE: The Journal of Physical and Chemical Reference Data (JPCRD) is published quarterly for NBS by the American Chemical Society (ACS) and the American Institute of Physics (AIP). Subscriptions, reprints, and supplements are available from ACS, 1155 Sixteenth St., NW, Washington, DC 20056.

Building Science Series-Disseminates technical information developed at the Bureau on building materials, components, systems, and whole structures. The series presents research results, test methods, and performance criteria related to the structural and environmental functions and the durability and safety characteristics of building elements and systems.

Technical Notes-Studies or reports which are complete in themselves but restrictive in their treatment of a subject. Analogous to monographs but not so comprehensive in scope or definitive in treatment of the subject area. Often serve as a vehicle for final reports of work performed at NBS under the sponsorship of other government agencies.

Voluntary Product Standards-Developed under procedures published by the Department of Commerce in Part 10, Title 15, of the Code of Federal Regulations. The standards establish nationally recognized requirements for products, and provide all concerned interests with a basis for common understanding of the characteristics of the products. NBS administers this program as a supplement to the activities of the private sector standardizing organizations.

Consumer Information Series-Practical information, based on NBS research and experience, covering areas of interest to the consumer. Easily understandable language and illustrations provide useful background knowledge for shopping in today's technological marketplace.

Order the above NBS publications from: Superintendent of Documents, Government Printing Office, Washington, DC 20402.

Order the following NBS publications-FIPS and NBSIR's-from the National Technical Information Service, Spring field, VA 22161.

Federal Information Processing Standards Publications (FIPS PUB)-Publications in this serics collectiv ely constitute the Federal Information Processing Standards Register. The Register serves as the oflicial sourcie of information in the Federal Government regarding standards issued by NBS pursuant to the Federal Propert! and Administrative Services Act of 1949 as amended, Public Law 89-306 (79 Stat. 1127), and as implemented by Executive Order H717 (38 FR 12315, dated May 11, 1973) and Part 6 of Title 15 CFR (Code of Ferderal Regulations).

NBS Interagency Reports (NBSIR)-A special series of interim or final reports on work performed by VBS for outside sponsors (both government and non-government). In general, initial distribution is handled by the sponsor; public distribution is by the National Technical Information Sernice, Springlield, 1:1 22161, 111 pipker copy or microliche form. 
U.S. Department of Commerce

National Bureau of Standards

Gaithersburg, MD 20899

Official Business

Penalty for Private Use $\$ 300$ 